\title{
WestVirginiaUniversity
}

THE RESEARCH REPOSITORY @ WVU

Graduate Theses, Dissertations, and Problem Reports

2018

\section{Affected Behavior: Deceptive Unities in Eighteenth Century Conduct Books}

Dominique Angela Bruno

Follow this and additional works at: https://researchrepository.wvu.edu/etd

\section{Recommended Citation}

Bruno, Dominique Angela, "Affected Behavior: Deceptive Unities in Eighteenth Century Conduct Books" (2018). Graduate Theses, Dissertations, and Problem Reports. 7164.

https://researchrepository.wvu.edu/etd/7164

This Dissertation is protected by copyright and/or related rights. It has been brought to you by the The Research Repository @ WVU with permission from the rights-holder(s). You are free to use this Dissertation in any way that is permitted by the copyright and related rights legislation that applies to your use. For other uses you must obtain permission from the rights-holder(s) directly, unless additional rights are indicated by a Creative Commons license in the record and/ or on the work itself. This Dissertation has been accepted for inclusion in WVU Graduate Theses, Dissertations, and Problem Reports collection by an authorized administrator of The Research Repository @ WVU.

For more information, please contact researchrepository@mail.wvu.edu. 


\title{
Affected Behavior: Deceptive Unities in Eighteenth Century Conduct Books
}

\section{Dominique Angela Bruno}

Dissertation submitted to the Eberly College of Arts and Sciences at West Virginia University in partial fulfillment of the requirements for the degree of Doctor of Philosophy in Eighteenth Century British Literature

\author{
Adam Komisaruk, Ph.D., Chair \\ Susan Greenfield, Ph.D. \\ John B. Lamb, Ph.D. \\ Rosemary V. Hathaway, Ph.D.
}

Department of English

Morgantown, West Virginia

2018

Keywords: Jane Austen, Frances Burney, British, Hester Chapone, Conduct, EighteenthCentury, English Literature, James Fordyce, John Gregory, Novel, Sarah Pennington, Samuel Richardson, Mary Wollstonecraft

Copyright 2018 Dominique Angela Bruno 


\section{ABSTRACT \\ Affected Behavior: Deceptive Unities in Eighteenth Century Conduct Books \\ Dominique Angela Bruno}

My defense argues that the eighteenth-century British middle-class conduct manual written for women is a suitable genre for beginning to understand the impossibility of a literature of advice. The inquiry is framed by the analyses and close readings of Nancy Armstrong, Margaret Anne Doody, and Mary Poovey. In the first chapter, I discuss the tension between intention and reception in the rise of both the conduct book and the British novel, by analyzing Samuel Richardson's Pamela, and Hester Chapone's Letters on the Improvement of the Mind. In chapter two, there is a discussion of motherhood and the inconsistent parental voice in Sarah Pennington's An Unfortunate Mother's Advice to her Absent Daughters, and Frances Burney's Evelina. Jane Austen's Pride and Prejudice is paired with James Fordyce's, Sermons to Young Women in the third chapter, where my critical inquiry focuses on how Austen commandeers Fordyce's tone, his religious language, and his ideas to create her narrative, while still mocking and satirizing his project. The final chapter highlights the differences between good conduct and virtue, and will expose the untenability of the conduct ethos, through the work of John Gregory in A Father's Legacy to His Daughters and Mary Wollstonecraft's A Vindication of the Rights of Woman. In the Epilogue, I discuss how these inconsistencies are still present in contemporary advicegiving, in both the book and the advice-column format. I conclude by suggesting that what the contemporary advice columnist is offering readers, is the possibility that intrinsic hypocrisy is not fatal; it is just a symptom of the disconnect between any reader and any writer of any text anywhere. 


\section{Table of Contents}

$\begin{array}{lll}\text { Title Page } & \text { i }\end{array}$

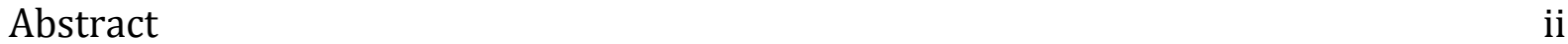

Table of Contents $\quad$ iii

Dedication $\quad$ iv

$\begin{array}{ll}\text { Introduction } & 1\end{array}$

Chapter 1: Conducted to Abstraction:

Samuel Richardson's Pamela and Hester

Chapone's Letters on the Improvement of

the Mind

Chapter 2: Conducted to Anxiety: Frances Burney's Evelina and Sarah Pennington's An Unfortunate Mother's Advice to her Absent Daughters

Chapter 3: Conducted to a Happy Ending: Jane Austen's Pride and Prejudice and James Fordyce's Sermons to Young Women

Chapter 4: Conducted to Absence: Mary Wollstonecraft's A Vindication of the Rights of Woman and Doctor John Gregory's $A$ Father's Legacy to His Daughters 
Dedication

To my grandmother Angela Bruno-whose tenacious and passionate pursuit of knowledge continues to inspire me-I gratefully dedicate this dissertation. 


\section{Introduction}

My experience as an academic advisor for undergraduate psychology majors has taught me that, when reality becomes overwhelming or difficult, the human impulse is either to control painful feelings and sensations, or to escape that which cannot be controlled. The literature of advice, by which I mean self-help books, advice columns, and manuals for proper behavior, has long been used as a tool to facilitate both of these impulses, with varying degrees of success. My dissertation argues that the eighteenthcentury British middle-class conduct manual written for women is a particularly suitable genre for beginning to understand the impossibility of a literature of advice. Conduct books and literature of advice-giving still have great influence today, since they help to create the fantasy that an "ideal" life is possible, while allowing the reader simultaneously to sympathize with and judge others from a safe literary (and emotional) distance. For all its attempts to arrest moral flux, the conduct manual is an intrinsically anxious genre, attempting to unify elements and ideas that are always in contradiction to each other.

Conduct manuals were meant to represent social norms, particularly regarding gender. But despite a tone ranging from gentle confidence to paranoid concern, they did not halt the march of time, cure social ailments, or usher in a new utopian era of perfected female citizens. Yet they were still published and avidly reprinted far into the nineteenth century, and versions of them are still printed in our own time. ${ }^{1}$ In trying to regiment gender norms, conduct manuals lay bare the impossibility of such a task.

\footnotetext{
${ }^{1}$ Lynne Vallone charts this trend, as does William St Clair.
} 
Though extensive research ${ }^{2}$ has already been done on the genre of the conduct book as a political tool, as a representative piece of culture, and as a representative piece of early feminist/gender theory, little has been written on its inherent structural instability. I will suggest that conduct books work towards their own failure by relying on a unifying definition of goodness (with which every reader supposedly can identify) while still being forced to engage with the fundamental differences present in ethical judgments and in human nature.

My argument rests on the fact that the act of reading is both objective and subjective. Kathryn Steele, in "Hester Chapone and the Problem of the Individual Reader," claims that eighteenth-century conduct literature works through injunction instead of recommendation, meaning that it tells readers what not to read and think, as opposed to what to read and think. Identity and morality are therefore created through absence, which becomes problematic when trying to define what is truly good. Moreover, the literature of advice writing is attempting the impossible, because following the advice does not determine holistic or intrinsically good character.

While eighteenth-century writers prescribe female conduct to project their own fantasies of moral consistency, the anxiety within the community of readers that suffuses the advice manuals themselves exposes this fantasy as unsustainable. I hope to prove that

\footnotetext{
2 The work of Nancy Armstrong, Mary Poovey, Kristina Straub, Patricia Meyer Spacks, and Joyce Hemlow has all helped to establish the link between conduct books, the eighteenth-century novel, and gender performance/identity. I believe that contemporary scholars such as Amanda Vickery focus too much on how conduct manuals represent their culture and not nearly enough on their efforts to shape it.
} 
the conduct manual as a genre ${ }^{3}$ is intrinsically unstable because it attempts to present moral goodness as a universal whole, yet its tools are ideas that are consistently in contradiction with one another. A conduct manual strives to be seamless, but it works with goodness in the only way possible: i.e. in pieces.

The word "conduct" originally meant "to lead with," and implied a private rather than a public concern. Ralph Robinson, in Christ All in All (1656), wrote that "It doth not become a sheep to refuse the Shepherd's conduct," meaning that divine guidance should be accepted silently $(O E D)$. By the seventeenth century, it came to refer to a public performance; good conduct was tied to good citizenship, and people who displayed it knew their place in society. The eighteenth-century conduct book acts as a mirror that society holds up so that a woman can see an idealized version of herself, but this idealized reflection is in itself a distortion. In the act of reflecting and behaving, there is a chance for the reflected behavior to be distorted, since the intended audience of the conduct book is behaving the way other people tell her to, not the way she wants.

One of the basic precepts I am working from is the fact that conduct literature may be generically unstable. The writer of the conduct book intends for their advice to be followed, or else there'd be no reason to write it; but the reader knows there is no external authority to control her following of the advice, so instead she can internalize it, and even ignore it if she chooses. Writing conduct literature in this way is a formal parallel to hypocrisy in moral practice. Moreover, the writer knows that the advice will most likely not

\footnotetext{
3 By "genre," I am referring to the conduct manual as a readable text. The tones of conduct manuals, with its occasionally religious platitudes, are meant to inspire comfort, but usually inspire judgment. Those feelings of judgment does not stop a reader from reading, though.
} 
be followed, because if it were, there would be no need for the entire genre of conduct literature. Still, the writer keeps on writing, to keep their job. This hypocrisy leverages awareness of the instability of the conduct book. We will see how the seeming unity of conduct books unwittingly reveals the conflict not only between authorial intention and reader reception, but between other binaristic elements of the genre itself, including, the conflict between public and private identities, and secular and sacred advice-giving. Carried through these different points of focus will be the idea that despite any claim to the contrary, writing itself can never be holistically understood. All writers and readers are susceptible to misunderstanding themselves (i.e. to being hypocritical) as well as one another. My chapters all vary this theme of instability by closely reading eighteenthcentury texts.

Each chapter pairs one conduct manual with a novel, novels, or a treatise that is in dialogue with it. Hester Chapone's Letters on the Improvement of the Mind, Addressed to a Young Lady (1773) is paired with Samuel Richardson's Pamela (1740) in order to focus on problems of intention versus reception. Sarah Pennington's An Unfortunate Mother's Advice to Her Absent Daughters, in a Letter to Miss Pennington (1761) is paired with Frances Burney's Evelina (1778) to show that the genre of advice-giving is both publicly and privately directed (specifically advice from mothers, who are conflicted regarding their own public and private citizenship and reputation). James Fordyce's Sermons to Young Women (1766) is paired with Jane Austen's Pride and Prejudice (1813) to contrast religious polemic and the literary satire that acts as a secularizing force. Finally, Dr. John Gregory's $A$ Father's Legacy to His Daughters (1761) is paired with Mary Wollstonecraft's A Vindication of the Rights of Woman (1792) to show that the ideas of right conduct are informed by a 
move towards a superficial—and therefore hypocritical—idea of what it means to be accomplished.

In my first chapter, I will discuss the tension between intention and reception in the rise of both the conduct book and the British novel. ${ }^{4}$ Chapone's frank discussion of conduct, intelligence and pragmatism contrasts with the dramatic prose of Pamela that propelled Richardson to fame (and that turned Pamela into a wildly popular eighteenth-century romance). Critics including Steele and Susan Allen Ford notice that two-thirds of Chapone's text is actually about reading: what to read, how to do it well, and what to do if parts of a text are difficult to understand. All the while, reading Pamela's letters comes to embody Chapone's fears that young women in the eighteenth century will fill their minds and hearts with frivolous and degrading forms of knowledge about sex and sensuality, because that is what is imposed upon them by aristocratic society. Richardson's concern with sexuality, as Margaret Anne Doody shows in A Natural Passion, is inseparable from his imaginative moral concern. The event in his novels is always an inner, or moral event, which shows his ideas about the nature of identity are inherently complex, though they are compelling and readable. Chapone's harsh judgments of novels like Richardson's reveal the breakage between intention and text. Since Chapone continues to misread works of fiction as cautionary tales at best (and at worst as salacious examples of sexual transgression) she is showing that conduct books continue to claim a unified idea of goodness, but in effect can only express how a text can be written one way, and read in a completely different way.

\footnotetext{
${ }^{4}$ A common anecdote is that Richardson started Pamela in 1739 as a sort of conduct book written in a colloquial style, for readers living in the rural countryside to troubleshoot problems they might be having with their upper-class employers. Later Richardson would form this conduct book into a romantic novel.
} 
In chapter two, I discuss motherhood and the parental voice in Sarah Pennington's An Unfortunate Mother's Advice to her Absent Daughters and Frances Burney's Evelina. In this chapter, I argue that advice posturing as altruistic is in fact self-serving. While mirroring good behavior onto her daughters, Sarah Pennington has the secondary aim of reforming her personal public face, as a woman of virtue who is able to dispense advice that is worth abiding by. Evelina uses the same genre and the same goal: to salvage a reputation that is assumed to be permanently damaged. Yet Pennington's public reputation, so completely destroyed, was only textually restored in her Letters; the happy ending to Evelina's upward social mobility "Cinderella story" gives the reputations of the titular character and her mother the more complete rehabilitation they deserve.

Evelina is a narrative of embarrassment and shame, and the reader might at some points feel uncomfortable with how much the letters share, or overshare. So it becomes interesting to mark the progression of Evelina's romance with Lord Orville in her letters to Reverend Villars. Her escalating shame ends up disclosing the depth of her own feeling, from her self-admonition, "But I must not expatiate upon this subject," all the way to her lament, "could I, upon this subject, could I write as I feel -- how animated would be the language of / Your devoted Evelina!" (Burney 74, 239). Evelina's development naturally veers towards the censorship of her writerly performance, as if to avoid embarrassment and shame from her reader. She learns not to laugh when she wants to at her first-ever assembly, or to write what she feels. Once she has learned that, she receives the appropriate feminine award of marriage. 
In my first chapter, I show how Hester Chapone understands that being a maternal figure such as an aunt ${ }^{5}$ is both a public and private role; that to build a reputation requires both public and private action, but that maternal advice forges a mother's reputation as much as it does her child's. Only the novel is able to perform the fantasy of a rehabilitated reputation, because it is only a fantasy. Comparing Pennington to Burney reveals how ineffectual conduct literature is at restoring a reputation and negotiates the tension between a created persona in literature, and a created persona in reality.

In the third chapter, I will map out the disjunction between religious and secular conduct. James Fordyce wrote his Sermons for godly young women, giving them a sacred code of behavior, while Austen wrote novels primarily to entertain by dramatizing and judging the problems of her world. Much has been written about Fordyce, ${ }^{6}$ but my inquiry will focus specifically on the religious ethos that made the Sermons both wildly popular and polarizing. ${ }^{7}$ Austen's overt references to Fordyce are characterized by a satirical tone. Satire can work as a secularizing force, because it breaks apart the monolithic nature of religious belief with doubt and skepticism. Secularity, according to the definition of Charles Taylor, refers less to religion, and more to a plurality of ideas (43). The way that Pride and Prejudice frequently veers into chaotic boisterous dialogue and spirited discussions is characteristic not only of Austen's style, but also of the way that her has the power of

\footnotetext{
${ }^{5}$ See Ruth Perry's 2006 Novel Revelations: The Transformation of Kinship in English Literature and Culture, 1748-1818 for more information on the importance of aunts and the role of ancillary maternal figures for children in the eighteenth century.

${ }^{6}$ See Katarzna Bronk, Nancy Armstrong, Vivien Jones, Ingrid Tague, and Karen O’Brien for discussions of the cultural importance of Fordyce's Sermons.

${ }^{7}$ Religious texts still outsold conduct manuals in the eighteenth century, and Fordyce, apparently an excellent orator, went about the creation and the publication of the Sermons with the very public aim of promoting female religious rectitude (St. Clair 131, 459-479, 539, 551-571).
} 
secularity, since it contains a multitude of voices and decentering the voice of her narrator. According to Taylor, "Secular reason is a language that everyone can speak and argue and be convinced in" (49). In this way, secularity is universal because it's diverse and subjective, but not unifying.

As Nancy Armstrong articulates, the common progression of any eighteenth-century novel is the happy ending of the virtuous woman united with a higher-ranking man, to exalt the heroine's virtue. My critical inquiry focuses on how Austen commandeers Fordyce's tone, his religious language, and his ideas to create her narrative, while still mocking and satirizing his project. All the while (in true Austen fashion) the readers are called upon to reevaluate previous scenes, to reexamine their own judgments of events that have transpired, and actively to grow and change with Elizabeth, making themselves feel that she is deserving of her romantic marriage-plot, while using un-romantic anecdotes to articulate the author's moral concern with vanity.

I use my final chapter to highlight the differences between good conduct and virtue, and will expose the untenability of the conduct ethos, through the work of John Gregory in A Father's Legacy to His Daughters and Mary Wollstonecraft's A Vindication of the Rights of Woman. The greatest tension in these final texts becomes an issue of esse quam videri: being versus seeming to be, essence versus construct. Where does the "seeming" end, and the "being" begin? Gregory references how he does not want his daughters to appear as strong, or witty or intelligent when they are interacting with men in public, even though they might be all of those things, and behave with wit and intelligence in the privacy of their own homes. He openly avows that a woman should behave differently out in the world from how she can behave in private. Mary Wollstonecraft is able to list all of the 
things that are wrong with a woman's education, but she does not offer concrete solutions to the problems that she has found. She wants women to be treated like rational human beings, but doesn't convey how that behavior is to be taught, and if it can be performed for the sake of politeness or not. From Wollstonecraft's dialogue with Gregory, as she creates a conduct book of her own in $A$ Vindication, it's clear that goodness is not a substance: it's an act. Even in the act of reading the texts, we perform the superficial: we can't get past the "seeming," because virtue for Wollstonecraft may be performative: defined in terms of actions rather than values.

Gregory's aggrieved tone of resignation in his Legacy is part of what authorizes his advice, but in contrast to Wollstonecraft, it also shows that his project is set up to fail. As readers we parse her words, but do not seek concrete answers to what makes people good or evil. Since the genre of conduct advice teaches the reader merely to appear virtuous, rather than to be it, the conduct text is intrinsically hypocritical. And despite Wollstonecraft's claim that she was writing the antithesis of a conduct book, the resulting Vindication reads like a conduct book itself, and lends itself to the same hypocrisy that any conduct book has. It's as much a fiction, and a fabrication, as any novel ever written.

My Epilogue addresses the persistence of the conduct or advice manual as a contemporary literary genre, present in "Dear Abby," "Dear Prudence," "Miss Manners," the writers of The Rules, Ellen Fein and Sherrie Schneider, and Cheryl Strayed's "Dear Sugar" Cheryl Strayed's book Tiny Beautiful Things: Advice on Love and Life from Dear Sugar (2012) is an anthology of her own columns from The Rumpus, a respected literary magazine, which couple autobiography with advice that might interest the "good girl" of the eighteenth century. Although Strayed is overtly applying advice of and for the self- 
absorbed millennial generation, she shows that the genre of advice has not changed very much at all since that time. Like Pennington and Gregory, her column tends to be more about her autobiographical anecdotes and writing style than the substance of her advice.

Only one advice book would actually be needed if advice literature actually worked. From my Epilogue, however, we can see that advice is not read because it works. We read the literature of advice to be entertained and enjoy its judgmental humor. Sometimes we are entertained inadvertently. That's why people are still reading the oftentimes disturbing The Rules, although it preaches a misogynistic mode of behavior that, when followed, would inevitably be devastating to a woman's self-esteem, not to mention her relationships.

We as contemporary readers, just as in the eighteenth century, take pleasure in voyeurism. In hearing salacious stories, we revel in the follies and errors of others. Perhaps what the contemporary advice columnist is offering readers, however, is the possibility that this intrinsic hypocrisy is not fatal; it is just a symptom of the disconnect between any reader and any writer of any text, anywhere. In our time, we know that neither reader nor writer can claim infallibility in the genre of the advice manual. But by bearing witness to our shared hypocrisy—reading and understanding that the advice we're getting is as imperfect as the person giving it-perhaps we are saving the conduct book from itself. 
Chapter 1: Conducted to Abstraction: Samuel Richardson's Pamela and Hester Chapone's Letters on the Improvement of the Mind

\section{Introduction:}

Can the fantasy of good behavior ever become a reality? In 1739, Samuel Richardson's friends ${ }^{8}$ suggested that he try his hand at writing a series of letters in a vernacular style, to advise any young women who might be entering into jobs as maids or in service on how to avoid attacks on their reputation or virtue. By 1740, Richardson's wife and her friends had persuaded Richardson to make the story of Pamela Andrews into Pamela: "a new species" of writing, with less "pomp" and parade than "romance-writing" and even, "tend to promote the cause of religion and virtue" (Dobson 26). However, the text's own overtly romantic plot actually became evidence that Hester Chapone would use in her Letters on the Improvement of the Mind Addressed to a Young Lady (1773) that ladies read this new "species" of literature, the novel, and had their minds filled with frivolous and hyper-sensualized knowledge, or emotions. Obviously, such knowledge would not be beneficial to the creation of morally upright British wives and mothers. ${ }^{9}$ In this way, the post-Chapone reception of Pamela bears out Chapone's and Richardson's concerns regarding the power of sensationalist novels.

\footnotetext{
${ }^{8}$ It's widely believed, therefore, that his friends Charles Rivington and John Osbourn were the initial inspiration behind Richardson's creation of Pamela. See Austin Dobson's 1902 Samuel Richardson for more about Richardson's writing process.

${ }^{9}$ Keymer and Sabor refer to critical pamphlets that described Pamela as "pornography in disguise" (22).
} 
While neither of these works directly engages with the other, ${ }^{10}$ each shows the primary failing of the conduct book: that its language contradicts itself, asking the reader to do several things at once. The juxtaposition of Richardson and Chapone reveals the failure of the latter. In receiving these two different modes of representation, the reader is directed by Richardson to read his narrative of good conduct ironically. Chapone is literal, and proper in her discussion of relationships, and attempting to create moral purity through instruction, but Richardson is dramatic, voyeuristic, and fantastic in his descriptions of virtue being consistently challenged. Richardson succeeds in the writing of his novel insofar as he distances himself from the conduct book and all of its limitations, but he also fails because he does not distance himself enough from the roots of conduct literature that created the foundation of his work. In this way, he is still writing a conduct book that is set up for failure.

Samuel Richardson wrote this hypothetical conduct book of his own for educating young female readers, and then transformed it into the new genre of "novel,"11 while Chapone's works to transform many of these ideas back into a conduct book, through her own intentions for her beloved fifteen-year-old niece. Since Chapone interprets many works of fiction as cautionary tales at best (and at worst as salacious examples of sexual transgression), her conduct book reveals the tension between a text's intended purpose, and how it is received by readers. The fact that these two elements might conflict with one

\footnotetext{
${ }^{10}$ Hester Chapone wrote to Samuel Richardson in the 1750's when she took exception to Clarissa's treatment in that titular novel, after Clarissa was bullied by her parents to marry, and refused. These letters, though only released posthumously, eventually became part of Chapone's Letters on Filial Obedience.

${ }^{11}$ And the word "novel" comes from the French word, "nouveau" which means, "new" and which was first used as a noun around 1500 (O.E.D., "novel," 2017).
} 
another is not lost on Richardson but might be lost on Chapone (who does not mention Pamela by name). Pamela as the site of those tensions becomes the conduct book in terms of reception. Richardson claimed in his introduction to the second edition of Pamela that it was written to, "promote Virtue, and cultivate the Minds of the Youth of both Sexes," but can his novel really do that (505)? Richardson appears to be aware (in ways that Chapone was avowedly not) that titillating, romantic prose gets attention from the reading public, and that even negative critiques are still forms of publicity.

Romantic love can be valorized, and construed as virtue, but sexual aggression and jealousy as romantic prose might accomplish the goal of selling more books to readers. As Pamela herself remarks with some self-awareness, her story could create "a surprising kind of novel, if it was to be well told" (246). I would argue that Samuel Richardson attempts to advise readers in the importance of good conduct (i.e., chastity, spiritual devotion, and obedience to real authority) but his readers received the text as an entertaining romance, with the moral of the story being that an enterprising attempt to raise one's social standing is the only real virtue.

Samuel Richardson was a printer first, and he understood that part of the printing business was selling the product. Hester Chapone didn't view her conduct manual, Letters on the Improvement of the Mind, in the same way. Her goals are more clearly to lay out the best way for her niece to live. ${ }^{12}$ Chapone's Letters was printed and reprinted

\footnotetext{
${ }^{12}$ Katheryn L. Steele argues that "Chapone's text suggests the pragmatic utility of a limited individual interpretive authority at a historical moment when women were excluded from the institutions through which interpretive authority was established" (489). In other words, the conduct book provided one of the few tools for eighteenth-century women to make their own morality.
} 
enthusiastically. William St. Clair estimates print runs of 1500 copies in the 1780 s, print runs of over 22,000 between 1800 and 1819, and an anthology print run in 1829 of 3,000 (592). People were buying Chapone's work well into the next century, but how were they reading it? Were they accepting Chapone's work as gospel, or were they trying to find the fissures and fault-lines in her rhetoric?

The reader has the power to receive the conduct book in whatever way she wants. Moreover, the writer knows that the advice will most likely not be followed, because if it were, there would be no need to for the writing of the advice (or for the entire genre of conduct literature). Still, the writer keeps on writing, to keep their job, and in doing so perpetuates the instability of the conduct book while holding to its illusion of wholeness and cohesion. In this way, the subject can appear to act properly within the different spheres of relationships that she resides in-proclaiming a universal paradigm of goodness, while all the time making decisions based on subjective realities. Richardson is always contradicting himself, as he tries to set up a new style of morality-writing, and juxtaposing Chapone with Richardson brings this contradiction in to relief, which leaves her text open for readers to judge, or find fault with her advice, as opposed to accepting her Letters as a good example of the literature of advice. Where Chapone fails, Richardson's novel is more successful as conduct literature, even though it is read through the lens of romance and sensuality.

\section{Literary Review:}


Many contemporary critics continue to look at Pamela's ability both to create character and, ultimately, to destabilize narrative. ${ }^{13}$ Critics have also discussed the instability of reader responses to Pamela as a text, including Richardson's almost obsessive need to respond to his contemporaries and critics through substantive revisions, the writing of sequels, or other novels engaging with the same themes (see Greg Morgan, Bethany Wong, and Bonnie Latimer). These critics help to prove the over-receptivity of Richardson to his critics, and the disjunction between intention and reception in Pamela's writing and re-writing. By trying to answer every critic's judgment, Richardson loses any hope for a unified message advice regarding moral goodness or sexual virtue in the novel Pamela.

It is Richardson's Clarissa (1748), not Pamela, that is largely considered to be the epitome of Richardson's talents; and it's not surprising that it was Clarissa that prompted Hester Chapone to write three letters to Samuel Richardson, taking exception to Clarissa's treatment at the hands of her relatives when she refused to be essentially sold off in marriage. The relationship between Richardson and Chapone, though not expressed in Pamela, is described by Betty Schellenberg and Laura E. Thomason, who engage with Chapone's letters to Richardson (which eventually became Letters on Filial Obedience, and then, after Chapone apparently reversed a couple of her positions, they became Chapone's A Matrimonial Creed). ${ }^{14}$ Thomason and Schellenberg show that Chapone is capable of 
responding and changing her opinions of what good conduct means, in a similar way to Richardson. Susan Allen Ford in "Assisting the Improvement of Her Mind" of 2014 also uses these interactions between Chapone and Richardson to show both authors' influence on the cultural thought of their time period. ${ }^{15}$ These critics show that despite the monolithic efforts of the authors, that contradictions still exist in their work, and that Richardson's work consists of elements of both conduct book and novel, thus the basis of its appeal to readers.

Kathryn Steele's “Hester Mulso Chapone” of 2012 shows the power of reading Chapone's work for its endorsement of female agency, and how such a reading could even lead to transgressive readings of the holy scriptures. Both authors had to either implicitly or explicitly contend with the fact that "consolidation of meaning" from each of their works is a fantasy, if not an "impossible dream" of a novel of development (197). In other words, all of the elements of both conduct book and novel exist together in Richardson's work despite these elements being in contradiction with each other.

In the following sections, I will discuss conduct and contradictions within the relational spheres of Pamela and Chapone, to show how Richardson's work remains in the genre of conduct literature, despite Richardson's claims of novelistic intent. First, I will discuss conduct between family members and members of society, then I will discuss conduct of spouses and partners, and finally I will discuss the self-regulating conduct of an 
individual, and how these three orbits of relationship work in both Chapone and

Richardson to create good character on the page. Neither Richardson nor Chapone can contend with how their work is perceived or judged by readers, no matter how hard they might try to create the perfect textual examples of relationships, whether romantic or familial. The comparison of both texts reveals how Richardson's text shows all of the elements of a piece of conduct literature, wrapped in the elements of the novel.

\section{Conduct in Parental and Conservator Relationships:}

As in any traditional bildungsroman, the heroine of Pamela begins her story as a girl under the conservatorship of her employers. Her parents are the recipients of her letters but are not actively raising or protecting Pamela. Readers are able to watch how Pamela conducts herself in relation to these parental surrogates. Her first custodian is Mrs. Jervis in Bedfordshire, followed by Mrs. Jewkes in Lincolnshire (Mr. B's two estate houses). After Mrs. Jewkes, Pamela will accept Mr. B's proposal of marriage. ${ }^{16}$ All do a poor job of caring for Pamela, and occasionally assist Mr. B in his plots to imprison her or abuse her. But the poor behavior of Pamela's parents and guardians adds to the drama of the story, while Hester Chapone's discussion of parental relationships remains a measured view of the ideal parent-child relationships and doesn't spend much time talking about the kinds of abuses that a young girl might suffer at the hands of her guardians.

\footnotetext{
16 It's also worth noting that Mr. B's London house is never put in play. In all his nefarious schemes to seduce and "ruin" Pamela take place far away from the cosmopolitan vices and dangers of the city. This allows for Mr. $B$ to be the private puppet-master of all the schemes that involve Pamela, because he can escape scrutiny. More important, Mr. B is very much in control of what is public, and remains so, through the entire text. He profits from the fact that Pamela is alone and seemingly friendless.
} 
Mrs. Jervis—a woman like Pamela's own parents-is a person of honor and respectability, who might have descended lower in social class due to extenuating circumstances (Richardson 17). She loves Pamela, though she is not as intelligent as Pamela is, and seems to appear in Pamela's writings to marveling at Pamela's faith, filial devotion, and virtue claiming that Pamela has a "Justness of Thought above [her] years" (Richardson 61-62). (The implication is that Mrs. Jervis did not have such justness of thought at Pamela's age, and might still lack it.) But as soon as Pamela feels the threat of Mr. B's presence at the Bedfordshire estate, she asks to share her bed with Mrs. Jervis, Mrs. Jervis readily complies, and Pamela immediately feels safer.

Despairing of her own poor fortunes, Mrs. Jervis wishes that she had the power to, "live independent, that then she would take a little private House, and [Pamela] should live with her like a daughter" though financially that is impossible (Richardson 26). She is ready to compliment Pamela's wit and mental acuity at every turn, but also to highlight Pamela's Christian faith and devotion to her parents. Unlike Chapone, who can claim both an age and experience superior to that of her niece, and therefore to dispense advice from this position of authority, Mrs. Jervis is clearly inferior to Pamela, at least in understanding, if not age. She is also inferior to the Mrs. Jewkes who replaces her because she has a gentler, moderate personality that makes her relationship with Pamela into a form of companionship instead of conservatorship. While Pamela claims her as her very best friend, she does not fit the role of best friend that Chapone describes as the most esteemed relationship that Chapone's niece can enter into. Chapone pulls on classical philosophy, when she discusses Aristotle's definitions of friendship in the Nicomachean Ethics: the best kind of friendship is based on goodness and occurs when two good people are friends for 
friendship's sake (Chapone v. 2, 137, Walker 180). ${ }^{17}$ Friendship has an abstracted level of esteem for Chapone, and the fact that Mrs. Jervis can't do a good enough job improving Pamela's mind, and cultivating her moral fiber is a detriment. Pamela's relationships fall short of what Chapone will later prescribe, which means that Chapone's ideals are as unrealistic as Richardson's romantic descriptions are, just in a different way. Richardson is faulting Pamela's conservators, but also faulting the ideal of platonic love in any form.

Like most servants at the Hall, Mrs. Jervis respects Pamela in her own way, and protects her in whatever way she thinks possible. When Pamela leaves the Hall, it is apparently quite affecting to all the servants there, even to those who will soon betray her (Richardson 99-101). Mrs. Jervis also understands what would happen to Pamela if she were to be alone with Master B, though she is just too weak to stop the inevitable. Pamela will later compare her ill-treatment at the hands of Mrs. Jewkes to her happier memories of Mrs. Jervis when she is captured by Mr. B. She is taken away from Mrs. Jervis' charge, and exposed to terror, betrayal and assault that comes horrifically close to a rape. When Pamela returns to the Bedfordshire estate as a newly married woman, she greets Mrs. Jervis as a daughter would, and takes pains to bestow care, attention and even gifts on her, now that she is mistress of the estate and lady of the manor. Pamela is now in the dominant authority position in the household, and it is a position defined by her generosity (compared to the helpless young maid she was before, who lacked the agency to be generous). While the happy reunion with Pamela's mother occurs off-site, after the

\footnotetext{
${ }^{17}$ Hester Chapone might rely so much on a community of female friendships to support and sustain her niece because she was part of the literary women, or "Bluestocking" movement in eighteenth-century Britain. She dedicates her Letters to Mrs. Montagu, another member of the same circle (Chapone iii).
} 
narrator/interlocutor has assured the reader that it has happened, and that every character got the "happy ending" that they deserved, it's clear that Mrs. Jervis as a motherfigure is the easiest parental placeholder for Pamela, compared to the odious Mrs. Jewkes.

Mrs. Jewkes of the Lincolnshire estate is a poor parental placeholder, being a crude, apparently ugly woman who does not at all respect either Pamela's opinions or her body, but constantly comments on her physical shape and appearance from the day they meet (Richardson 107). It is very clear that she delights in Pamela's physical attractiveness in ways that the modern reader might interpret as homoerotic, and eighteenth-century readers would immediately recognize the overtly sexualized bawd character, who appears on many stages, and in a variety of texts throughout literary history. She makes vulgar jokes and insists on sleeping in the same bed with Pamela and getting kisses. She also slaps Pamela, when they are out walking in the garden, and is content to continue abusing Pamela, and seeing her "Ruin" as certain. She might even enjoy watching it, as she tells Mr. B to hurry up and rape her, so that she will be quieter once she has been deflowered (Richardson 203). It is Mrs. Jewkes who holds Pamela's arms and hands as Mr. B enters their bedroom—or "closet" — disguised as the maid, climbs into bed, and attempts to assault Pamela as she swoons and faints in fear (Richardson 203). The only thing that Mrs. Jewkes is devoted to is Mr. B's word, because she follows his every order so exactly, claiming that "he is her "Master and if he bids [her] a Thing that [she] can do, [she thinks she] ought to do it" (Richardson 110). Pamela is appalled by a woman who has no spiritual code, and instead relies on the orders of a human man. But readers might not be surprised by this, considering that Pamela spends so much time in prayers to God, and that her biggest regret during her imprisonment is that she is not allowed to attend church 
(Richardson 113). Perhaps she does not have a Bible to read, because Mrs. Jewkes perhaps is not one to carry religious texts.

Pamela proves her right virtue in every single way available to her, not only by resisting the advances of Mr. B, but also in writing her prayers, psalms, and songs of devotion down in her letters to her parents. If good Christian conduct can be defined as a spiritual form of obedience to a higher authority, the most meritorious thing she does in the text is constantly claim devotion to her parents at every available opportunity. She ends her letters to her parents several different ways, most commonly with "Your dutiful Daughter" (Richardson 18). When she realizes that she is falling in love with Mr. B, she even apologizes in her letters, for doing so, as if she has not been respectful enough (Richardson 248-249).

Her father's presence at the Lincolnshire estate brings Pamela's raptures that he himself freely joins in—as soon as it has been established that her sexual virtue has been safely ensconced in a marriage. Pamela has followed her social and moral script and is safe from harm. She is therefore allowed to be happy, and Mr. Andrews can return to his wife, and tell her the good news. For the most part though, Pamela's parents will continue to be supplanted after her marriage (the numerous sequels to Pamela focus on her married life to Mr. B). If Pamela's parents were as financially stable as Hester Chapone's nieces were, the entire narrative of Pamela might have not even happened. The Andrews' socioeconomic fall from grace becomes another part of the romantic plot of Pamela's "Cinderella-story" and their real sufferings and anxiety about their daughter might even read as trivial, considering Pamela's lucrative success on the marriage market. Pamela presents a 
narrative of failed conduct, insofar that her guardians fail to guide her correctly. It is her morality that guides her conduct correctly at every encounter with vice, not the advice of her parents or guardians. These failings are further highlighted by comparing Pamela to Chapone's Letters, which endorse a communal model of good conduct that is also unsuccessful with the reader.

Of course, Chapone's love for her family creates her own bias, and moves her text towards the conflict between intention and reception. ${ }^{18}$ The more compelling narrative is still Richardson's story of Pamela's sexual virtue continually put in danger through inadequate guardianship that does not enact any of the good advice that the reader knows should be followed. (After all, Pamela's parents want her to return home after the death of her mistress, and Pamela's refusal to do so results in her marriage-plot.) Chapone's advice, while coming from a well-intentioned place, does not capture the imagination nearly so well as Richardson's epistolary novel, and her advice can be easily disregarded as a result. Richardson's prose entertains more, because the reader can suspend disbelief more easily, and therefore ignore any contradictions, such as the fact that seduction is immoral, but might also be pleasurable. From the juxtaposition between both texts, we can learn the flaws inherent in the conduct book are there from its inception, even though authors attempt to work through these flaws and respond to their critics in the act of writing. Looking at parental types of relationships in Richardson and Chapone shows how the

\footnotetext{
${ }^{18}$ Bethany Wong argues that though Samuel Richardson attempted to assert his authority over his fictional characters through many sequels and writing into other genres to respond to his critics, "neither he nor his heroine could prevent the struggle of interpretation" (197).
} 
reader's virtue was never determined by the advice that she is getting but always by the decisions she makes to behave in a sinful or virtuous way.

Chapone's Letters do not work from a fairy-tale place of a heroine deserving her upgrade in class position. The intended audience of Chapone's Letters has the good fortune of a higher class and better economic standing than the young heroine of Pamela has (and has the loving, focused attention of both Hester Chapone and her own parents, whom Chapone seems to admire, or at least respect). Though Chapone is not a parent herself, she understands the plight of a young woman having to navigate society for the first time, and how vulnerable that young woman is. As a result, Chapone is very careful dispensing her advice, and is aware that such advice might be contradicted in real time, by parents, or by other authoritative voices. But it's Mr. B.'s assessment of Pamela's goodness, a more dramatic assessment that relies on the power of romance.

After their reconciliation, Mr. B praises Pamela's virtue to her father, saying that, her “Virtue was Proof against all Temptation, and was not to be aw'd by Terrors: Wherefore as [he] could not conquer [his] passion for [her]" he corrected his own behavior, and resolved to have her on her own terms; ceding all his power over to Pamela's true charms (Richardson 299). Pamela apparently has learned the correct way of controlling her relationships by the warning of the inadequate guardianship that she had to endure prior to her marriage. The patriarchal balance of power is restored, but Pamela is proven to have far more agency, and matrimony represents her salvation.

\section{Good Conduct in a Spouse:}


While the ideology of companionate marriages became more pervasive in the eighteenth century, the marriage contract might have been a more recognizable trope for the reader. The concept of the marriage contract is manipulated throughout Richardson's text through two contracts, both written by Mr. B to be signed or recognized by Pamela. The first is given to Pamela before she marries Mr. B, which designates what her role as his mistress would be. As Pamela rejects Mr. B's "Mistress Contract," she transcribes and annotates it in her journal in the hopes that her parents will end up reading it. These annotations offer a chance for Pamela to reject the material comforts that would be bestowed on her and her parents, were she to agree. But for her parents' sake, and the sake of her own virtue, she constantly repeats that she could never stoop to the place of a "baseborn prostitute," even if Mr. B does follow through with his articles, wherein after a trial period of a year, he might consider marrying her (Richardson 191-192). Pamela has assured her readers (including her parents) that despite anything that has happened to her, she has the "Soul of a Princess; though [her] Quality is inferior to that of the lowest slave" (Richardson 158). She is refusing Mr. B's explicit contract because her implicit code of virtue that she promises to display when she writes to her parents is the true inviolate contract. She writes in order to preserve, or at least not to harm their reputations or cause them shame. Since her parents spent their first letters to their daughter reminding her ceaselessly that her virtue (her purity or chastity) was her one jewel, it's not surprising that she spends the greater part of her imprisonment claiming that she would rather lose her life than her virtue (Richardson 14). Mr. B as the ogre, possibly the rapist, and definitely as 
the "Beast"19 to Pamela's noticeable "Beauty"20 sets up the contrast that creates the drama of their love story, a love story that would not be possible without Pamela's attempt to preserve this virtue.

For Pamela, the romance narrative is supposed to be realistic, ${ }^{21}$ in its realization of her marriage to the brilliant handsome aristocrat, but this realism does require a behavioral contract, which although not signed, is immediately internalized by the heroine. She reflects ${ }^{22}$ on what her marriage will entail to her parents, after Mr. B gives her a list of what he would like to have happen in a romantic form of the "Marriage Contract" and reflects on his list with one of her own: a list of what will make a good marriage work, including that she must "think [her husband's] Displeasure the heaviest thing that can befal" her (Richardson 368, 448). The rigidly hierarchical matrimonial roles play out, because Pamela spent so much time in Mr. B's thrall, with no power whatsoever, and regards her marriage as a form of recognition, validation and agency. Now that she is a lady, married to a wealthy gentleman, her power will not overreach itself, because she is prepared to submit readily to her husband's will, as she has done throughout the entire text.

\footnotetext{
19 Richardson's use of the letter "B" can also connote this fairy tale, as well as allude to the Bluebeard story. ${ }^{20}$ Another popular fairy tale of the eighteenth century was Madame Leprince de Beaumont's La Belle et La Bête translated into English as "Beauty and the Beast" (de Beaumont 8). First published in French in the 1740 's and 1750's, it remains one of the most enduringly popular fairy tales of all time and has been adapted into numerous illustrated books and films.

21 Bethany Wong also describes how Richardson's sequel to Pamela was used to defend his own authorship, and the transform the fantasy of the theatre into a means of virtuous authorship as a whole (179).

22 De Beaumont's Beauty also reflects "on herself," after she has abandoned the Beast, and these reflections result in her returning to his side, and eventually breaking the spell, transforming him back to a prince (de Beaumont 23).
} 
Regarding love, affection, and other forms of emotional conservatorship, Hester Chapone spends a lot of time reminding her niece not to engage her heart or affections without exercising her mind and judgments. In truth, she spends more time telling her niece how to make friends and set up a good support system among women, than she does supporting the institution of marriage. Whenever possible, Chapone decenters matrimony and valorizes homosocial bonds. However, her rules for friendship and for finding a good husband elide in several areas, including that the person chosen must be an observant Christian, have a good reputation, have a reasonable mind, and a refined temperament (Chapone v. 1, 160). Jealousy and possessiveness, as well as bad reputations for salacious behavior would not be encouraged by Chapone. But every human being is flawed, and compromise is necessary in all relationships, even if it is not necessary in Chapone's version of a husband. By perpetuating this idealized version of a spouse, Chapone's conduct literature falls into the same trap that Richardson's novel does, in that it is unrealistic. Both of these texts conflict with their own aims: Richardson's goal to entertain his readers with a new genre of writing, and Chapone with her perpetuating generalized virtues that resist definition or articulation.

Pamela has already described how her position is society isn't clearly defined, because of the conflict between her accomplishments and her occupation: she was trained and guided to a higher station in life yet works as a servant. Mr. B's mother did not expect that she was raising a wife for her son; nevertheless, that is necessary for the rags-to-riches plot of Pamela's love story. Pamela's ceaseless repetition and recognition of her own virtue cannot change the details of her abduction, which reads as tense and dramatic (and in fact 
traumatizing) but are clearly a fantasy designed to appeal to the emotions. ${ }^{23}$ Hester Chapone's authorial-self attempts to take on the position of sage advisor by giving guidance that is abstracted and claims to be dispassionate. She warns her niece that, though she would by no means "exclude the kind of reading, which young people are naturally most fond of, "the greatest care should be taken in the choice of those fictitious stories, that so enchant the mind-most of which tend to inflame the passion of youth, whilst the chief purpose of education should be to moderate and restrain them" (v. 2, 144). Richardson is not mentioned, but clearly his novel sold many copies, because it was doing just that: his dialogue, and sexually tense moments are designed to inflame and scintillate, ${ }^{24}$ while Chapone's is designed to "control" and "restrain." 25 Though both writers employ similar language to describe good behavior and vice, even Chapone can acknowledge that prose like Richardson's is designed to create or incite passion.

Because it does not rely on a romance plot, Chapone's language reveals the hollowness of some abstracted ideal of conduct book, compared to the depth and intensity that Richardson can bring to a fictional narrative. However, both authors struggle to meet their goals in the writing. Neither the romantic fantasy, nor the clinical description of

\footnotetext{
${ }^{23}$ Janice Radway's 1984 Reading the Romance: Women, Patriarchy, and Popular Literature uses Reader Response theory to analyze what contemporary women find so appealing in modern amatory novels. Her conclusion is that the pleasure in reading romance is not tied as much towards sexual desires and wish fulfillment as it does with displacing the fear and anxiety of male dominance in our culture.

${ }^{24}$ Radway's recommendation in the second edition of Reading the Romance from 1991 is that contemporary romance novel readers should form feminist communities to fight their anxieties about patriarchal society, as opposed to acting out their fears in the solitude of quiet imagination.

${ }^{25}$ Betty A. Schellenberg in "Coterie Fam, Media Choice and the Writing Lives of Hester Mulso Chapone and Catherine Talbot," talks about how even as a young woman, Milson "clearly found the literary mentorship and encouragement of older men, such as Richardson himself, valuable" even though Chapone only wrote to Richardson in 1751 regarding Clarissa, not Pamela (319). In these parts of her conduct book, it is clear that the voices of these older mentors were in Chapone's head, the same way the voices of the classical philosophers helped her define her terms.
} 
relationships between a young woman and her spouse leave the reader of either text with a realistic vision of what married life might be like. Both the conduct book and the novel struggle to depict how a young woman's good conduct of herself is meritorious and worthy of credit, and they both struggle to realistically depict the reality of personal virtues that are actually rewarded.

\section{Good Conduct of One's Person:}

Perhaps more important than good conduct as a daughter or as a spouse is good conduct (or good control) of oneself as a person, through the maintenance of a good character. For Pamela, this must go beyond whether she is virtuous (i.e., chaste). As a character in a novel, this is Pamela's central conflict: how is she to create a "good character" to display to her parents, to Mr. B., and to the world?

The only solution is within the plot of the novel, and within its epistolary format that can hold the reader's interest as this issue is investigated over and over. Pamela writes obsessively—even neurotically—-to recount and validate her feelings, but she also cannot create herself as a "whole" character, because the method of delivering her narrative is unreliable. Her dead mistress has taught her talents and accomplishments that have given her "qualifications above [her] degree," so she doesn't really belong to the servant class; but neither does she belong to the aristocracy (Richardson 11). ${ }^{26}$ Since Pamela lacks a place

\footnotetext{
${ }^{26}$ Christopher Flint, in "The Anxiety of Affluence: Family and Class (Dis)order in Pamela, or Virtue Rewarded" determines that Pamela at the beginning of the novel is in a state of "psychic ambivalence," because she has learned that her identity derives from "two clear and opposed sources of behavior, one teaching the value of bourgeois industry, 'honesty,' and 'virtue,' the other establishing her aristocratic achievements-grace, learning, honor and philanthropy" (490). According to Flint, the rest of Pamela's novelistic time will be spent "seeking to establish an identity which synthesizes these two powerful cultural models of behavior" (490).
} 
of true belonging, this lack, and the anxiety around it then become the reader's reality when they are immersed in Pamela's voluble prose. The formal instability of the text, presented through Pamela's biased eyes, mirrors the socioeconomic ambiguity of her class position throughout the novel, and the result is a chaotic performance of writing being hidden, and discovered, and displayed. Pamela's writings are understood to be dashed away on papers to be distributed in fragments, in letters or notes that can be slipped under doors, or into bodices, or buried under rocks. Her tumultuous journey to marriage has her summarizing long periods of despondent paralyzing inaction, followed by the frenzy of new knowledge and finally concluded with long reflections. The narrative arc is inconsistent, and Pamela's vision of herself vacillates between two class positions, belonging to no-place, reveals that she is an inconsistent character as well.

As a writer, Pamela claims that her letters, and her "words" are really all she has, when she has been imprisoned, and robbed of any agency. But narrative interjections, like the one that Samuel Richardson inserts during Pamela's abduction from Bedfordshire to Lincolnshire, are then even more jarring for how they disrupt our understanding of Pamela's reality. The narrator notes:

Here it is necessary to observe, that the fair Pamela's Tryals were not yet over; but the worst of all were to come, at a Time when she thought them all at an End, and that she was returning to her Father: For when her Master found her Virtue was not to be subdu'd, and that he had in vain try'd to conquer his Passion o'r her, being a Gentleman of Pleasure and Intrigue, he had order'd his Lincolnshire Coachman to bring his Traveling Chariot from thence... and carried her onward towards his Lincolnshire estate (Richardson 92). 
Almost all this information would be relayed through Pamela's letters and the return of her voice in the next section, but the narrator felt the need to mention this sort of intrigue, and not through the epistolary form. The narrator will also provide a "happy ending" epilogue to Pamela's story, but the interjection is more significant, because in many ways, it is superfluous to the "moral" that is provided at its conclusion, a moral that declares virtue, (i.e. integrity) in all aspects of life, is the only thing necessary to make a person "good" (Richardson 500). Richardson provides examples of what each kind of person, including, "Clergymen," "Upper" and "Lower" Servants, the rich, and children, will get from the story of Pamela, but an adherence to virtue, or behaving with integrity is really the best cure for the faults in human behavior (Richardson 499-501). Pamela however, never had a say in how her goodness would be challenged or put on trial.

In the novel, Richardson-as-Narrator seems to believe that Pamela's fate must be put in doubt, to keep the reader invested. Mr. B refers to Pamela's story as a, "plot" many times. (In fact, between Mr. B and Pamela, the word, "plot" is used almost forty times in the novel.) Mr. B's sinister plot to rob Pamela of her purity (though it is thwarted in the face of Pamela's virtue), as well as the many schemes he must use to please and gratify her after their engagement, as he is planning the wedding. That is how Pamela views it too. She sees Mr. B's plots-especially his disguises—and attempted rape as horribly evil plot points, and his generosity and gift-giving as evidence of his reformed character within her romantic plot. While providing distance from the trauma of the events, the use of the word "plot" calls attention to the machinations of the editor of the letters, and the narrative voice when it appears. Plotting reveals the artifice within the high drama being performed on the page. It also works to remove Pamela's agency. She is a character in someone else's story or 
playing the part of a heroine to prove the narrator's point that she is actually virtuous, but she didn't have a choice in the matter.

The only other time that the narrator's voice interjects is to justify its ending, after Pamela and her parents are reunited after her marriage to Mr. B, and the narrator claims that she had, "no Occasion to journal longer" (Richardson 498). When she talks about her future as a married woman to Mr. B, writing still plays a part in the overall story, and Mr. B claims that she will be able to write in her leisure time, but Pamela does not speak at the conclusion of her tale. ${ }^{27}$ Perhaps her letters betrayed too much female self-agency for an $18^{\text {th }}$-century reader to understand, and therefore must be rhetorically silenced by means of filling her life with happier duties and obligations that Mr. B can work to control. ${ }^{28}$ Before their marriage, Mr. B demands to see Pamela's writing, and he reads them and reflects on them with Pamela after their marriage, going as far as to share them with his sister when they are reconciled (Richardson 454). Once Pamela's voice (and her ability to recall events with a meticulous level of detail) has been appreciated, it will be allowed to fade and diffuse into her role as wife, mother, and lady of manor house. Narrative interjections give the impression that Pamela lacks the power to self-fashion beyond her letters, and work to organize the conduct manual that the novel is creating.

${ }^{27}$ Marina Warner claims that though gossip is a seventeenth and eighteenth-century instrument of selfassertion, muteness is just as much another "stratagem of influence" (Warner xxv). Silence, or a lack of speech can move forward a plot and change the attitude of the characters.

${ }^{28}$ Dell Belew discusses how Richardson wants to talk about how good writing can be used to instruct young women, but, "what he fails to tell the young women is that writing is the first threat to their virtue" (174). Pamela will gain her Mr. B, but she will be forever being "destined to write his biography" which will outshine her own. 
Mr. B is well aware of the genre of story he and Pamela are performing. He complains that Pamela's fate is too much like that of a romantic heroine, and that the two of them will, before the end, make "a pretty Story in Romance I warrant" (Richardson 32). It's easy to assume that Mr. B read the sorts of books that Hester Chapone is so wary of. Clearly Mr. B was used to romantic intrigues, and dearly wished for an intimate encounter with Pamela, who was, in his mind, being coy, and claiming that her virtue would sustain her. Though Richardson claims that he is defining his "novel" form against romance, the characters of his novel have slid in to their expected moral tropes of good and evil. Whatever Richardson's goal in the writing was, each of the characters in Pamela is playing a part: the lowborn virtuous servant who desires something more from life, the high born spoiled aristocrat that has never heard the word "no," the good servant who has fallen on hard times, etc. Perhaps Pamela's trajectory into upwardly mobile society is supposed to subvert her archetype of ingénue, but her desire for a higher-class position, and her "soul of a princess" becomes the fairy-tale archetype, as it is her destiny to be rewarded for her good behavior (Richardson 158). ${ }^{29}$

All the advice that Hester Chapone gives her niece is in the form of the direct address, like a long speech. And like a long speech, it can lose the reader's attention. Chapone wanted to prove to her niece about the kind of life that good conduct can afford a woman is overshadowed by the romance of Pamela's marriage-plot. Though Pamela follows none of the advice that Chapone would have given her, (she is married early, to a

${ }^{29}$ The emphasis in the original fairy tale, rags-to-riches romance of Perrault's "Cinderilla; or, the Little Glass Slipper" is on the virtues of the heroine, who favors her dead mother, and is truly, "the best Creature in the World" (59). 
reformed rake, and has no community of women friends around her to support her) it's Pamela's story that captures the imagination.

Pamela's artifice is constructed, and obsessively self-aware, because her captivity does not let her ignore her situation, and the artificiality of her writing is all she has. She knows that she is her letters, pure and simple. While Pamela is unable to truly self-fashion apart from her textual nature, that textual-self is very aware. This obsessiveness is what troubles Hester Chapone about novels like Pamela: that self-awareness of performing, and the awareness of the reader's inevitable emotional investment in the performance, throughout all of Pamela's trials, as she writes her way into her awarded virtue (Chapone v. $2,146)$. Chapone is making a stand for what she believes is an authentic being as opposed to a novelistic seeming, whether or not she is correct, and whether or not her readers will be able to spot the difference between the two ideas. Readers of novels could indulge in their passions in a way that Chapone found to be damaging. Perhaps it was because novels don't have to be so literal. ${ }^{30}$ Readers enjoy the suspense and wanted to see how the manipulations of class and sexual power played out. They didn't want it described to them, they wanted to be immersed in it. Chapone urges her niece to never read such novels, because her heart will become, "corrupted" (Chapone v. 2, 146). For her niece to give so much attention to the amatory aspects of Richardson's text also means that the reader is giving that same attention to the diabolical stratagems of the rakish Mr. B, and might even find them appealing enough to look for a man like Mr. B to marry, which might devastate

\footnotetext{
${ }^{30}$ Slate.com ran Stephen Metcalf's piece satirizing the parallels between Pamela and the pop-culture phenomenon of 50 Shades of Grey with the same premise: "The Life Span of the Novel, From Pamela to Fifty Shades of Grey: What the professors of the future will tell their students about E.L. James' erotic opus" on February 27, 2015.
} 
aunt Hester Chapone, and any guardian invested in the emotional well-being of their charge.

\section{Conclusion:}

Looking at both Richardson's novel and Chapone's epistolary conduct book reveal how both authors might have had differing goals in their writing, but both authors ended up writing texts that did not necessarily align with either set of goals. Neither writer can make their readers think exactly as they did when they were writing; neither author can successfully persuade readers to behave in a virtuous way, just by reading what they wrote. Hester Chapone's aspirational tone is forever at odds with her reader's judgments, and Richardson relies heavily on the clichéd or archetypical black-and-white rendering of good and evil in his characters, so that he ends up writing a conduct book again.

Reading Pamela solely as a novel is challenging because of the repetitive nature of Pamela's language, but reading it as a conduct book is also a bit of a challenge. Mallory Ortberg, a former humor writer for the feminist blog, The Toast, and now the author of Dear Prudence for Slate.com, wrote two pieces about the art and artifice of the novel Pamela that relate to the way readers, (especially contemporary readers) might experiences Pamela for the first time. Ortberg worries that the reader, "might hate it, or worse find it boring, or distractingly full of horrific sexism and classism, and [therefore] miss out on a good time" (Ortberg "Revisiting" 2014). The text does offer entertainment in a traditional fairy-tale way: it's a happy marriage plot, and we are rooting for our heroine throughout her trials and tribulations. And when Pamela gets her virtuous reward, we get 
to see her "happily ever after" as much as we want to, and no more. The narrative conveniently cuts out before any scenes of her (perhaps boring) life with Mr. B, when she is a charitable manor patroness, and a mother. Though we as readers see more of her married life than is usually supplied in a fairy-tale, the exposition of Pamela as a wife is the falling action after the climax of her near-rape, and mostly works to bring the reader to a "happy" resolution.

However, Ortberg also notes the other problems inherent in the text from a contemporary standpoint, because it is also a, "seething mass of uncomfortable compromises and mental torture" (Ortberg "Revisiting" 2014). Yes, this Master of the house is attempting to seduce his sixteen-year-old dead-mother's maid; yes, he succeeds in kidnapping her, getting her into a bed; and with the help of his housekeeper holding her down, he almost does the deed. All that is true. And it is phrased in breathless eighteenthcentury prose where the sentences are piled on top of each other like layers of a trifle; you might end up feeling sick before the end. Or maybe as Ortberg might say, you end up feeling crazy: "It's so incredibly over-the-top that somewhere after the kidnapping but before the secret sunflower letters you start to feel like Richardson's making you watch someone strip in front of you while insisting they're not getting naked" (Ortberg "Revisiting" 2014).

Like all humorists, Ortberg works from a truth: as a fable-working with a known moral-Richardson's text can make the contemporary reader feel uncomfortably crazy, because the details of the compromises can be almost impossible to understand. All of the highly dramatic professions of love and desire feel human compared to the staid prose of Hester Chapone. Pamela's situation is terrible, and obviously dangerous. Her parents are 
begging and pleading with her in the first part of the novel to come home to them, [and she promises that she would, only she doesn't want to ruin all the nice clothes that her dead Mistress gave her; therefore, she'd better sew some more first). So, she will wait in good faith for Mr. B to send a carriage for her to go half-way, and thus walks right into her own kidnapping. If Pamela was on an unscripted reality television program, she would be the character who keeps doing wild things to keep the cameras trained on her always. But this is also a common trope. ${ }^{31}$

Yet Ortberg understands that there is no way out of this claustrophobic story without the other common trope of using the heroine's perfected femininity to reform the male hero of the story; in fact, changing his character beyond recognition. Richardson must reform the rake and make him into the ideal husband. Like many fairy tales, Richardson's story relies on the triumph of female weakness over male strength. Pamela really does lack agency. As Ortberg says: “Mr. B owns a lot of property all over England, and he sort of owns Pamela too. So, Pamela's position is fixed, and Mr. B's position is fixed, and there's only one winning move that she can make, and that is topping from the bottom like a motherfucker." (Ortberg "Revisiting" 2014). While Ortberg's informality is rather grating, it's also bizarrely accurate. Though perhaps not "topping from the bottom" 32 Pamela is able to manipulate her circumstances the only way that will solve her problem: through a marriage. She writes down her grievances to her parents and does nothing. She doesn't speak, until Mrs. Jewkes

\footnotetext{
${ }^{31}$ Frances Burney will use similar behavior traits to create characters like Madame Duval, Evelina Anville's grandmother, and Jane Austen will use them to create characters like Lydia Bennet.

$32 \mathrm{~A}$ phrase commonly used in sexual sadomasochistic situations where the submissive attempts to control the sexual situation through their own submission and passivity. Stephen Metcalf compared the story of Pamela to the story of 50 Shades of Grey, which popularized and made palatable elements of sadomasochistic relationships for contemporary readers with the same effect.
} 
complains that she's not an enjoyable companion. When Mr. B attempts to assault her, she swoons and faints, so Mr. B is sure that he has killed her. Only then does he realize that he cannot get inside her head without express permission, as he learns to be "Master of [himself]" (Richardson 206). And once he's asked to be inside her head, he might as well ask for her to be his wife. As Bradford Mudge says in A Whore's Story, "Using chastity to redefine womanhood, and love to redefine marriage, Richardson creates in Pamela the working-class solution to aristocratic ills" (187).

What's good (and romantic) about the story is that Pamela's behaviors work: she gets her socially upwardly mobile marriage, and her happily-ever-after. Ortberg says: "And she wins. [Pamela] wins everything" and her virtue is clearly rewarded (Ortberg "Revisiting" 2014). It's true that Mr. B becomes devoted to his dearest Pamela by the end of the novel, writing her songs and poems that she dutifully transcribes in her journal as evidence of his love, and waiting courteously on her father when he arrives at the Lincolnshire estate unexpectedly. Within the conscripted patriarchal British society that Pamela and Mr. B's readers inhabited, this is the perfect ending to the story. And it's worth all the insanity that the reader, and Pamela had to go through to get to this happy ending. However, this is a verbose happiness, where the superfluity of words overwhelms the reader, making clear through repetition of key verbal fragments like, "my Virtue" (Richardson 29, 84, 118) exactly what readers are supposed to get out of Pamela, and Pamela the girl-bride, elevated to the high life (or so eighteenth-century readers understood). Almost immediately, writers and critics would take Richardson to task for the entire novel of Pamela, and he would continue to write sequels and critiques and annotations of the work for a long time afterward, even using his later novels to grapple 
with the same themes in recast characters, 33 who are also being challenged to find their truly good moral centers in a world that continues to destabilize morality. Richardson is not indifferent to moral considerations, but he is making a stand for fiction rather than polemic as the vehicle for exploring them. By juxtaposing Richardson and Chapone, readers can see how intention does not always align with reception, insofar as both authors have goals in contradiction to each other but end up writing texts with similarly archetypical characterizations of good and evil, and non-specific language that is used to define what is good.

Conduct books, like their human subjects, are only able to work with goodness the way that people integrate goodness: i.e. in an uneven progression. The letters of an epistolary novel work in a similar way: they can only provide flashes of insight and situations that can be integrated into a whole narrative. Hester Chapone, in providing a united theme of community and the preeminence of reason, attempts to create one holistic notion of true virtue (as Richardson does in his concluding moral) but it can only be read letter by letter, and is too abstracted and generalized to resonate with the feelings of the reader. Though Richardson claimed that his virtuous Pamela was "no Shadow, but true flesh and blood," the tools of pen and paper are not adequate to claim goodness (Keymer and Sabor 107). There is no objective reality for a character created through the epistolary novel (like Pamela) or one being written to as its subject (like Chapone's niece).

\footnotetext{
${ }^{33}$ Critics like Bonnie Latimer and Laura E. Thomason argue that Richardson thought he had purified and perfected the innocent virtuous girl in the writing of Clarissa, the novel that Hester Chapone wrote to Samuel Richardson about in 1751.
} 
A novel strives to be seamless, and it is when Richardson's text repeats its conflicts that the reader can see the many aspects of the novel in contradiction with one another. Pamela's virtue versus her desire for Mr. B, Mr. B's desire for Pamela's body versus his desire to know her mind and heart, Pamela's own powerlessness versus Mr. B's aristocratic authority-all of these elements are always already in play in the novel, and therefore can develop in the mind of the reader. Richardson appears to be validating one thing through his overt moral - the triumph of the virtuous soul—while using romantic prose to actually validate something else-social mobility is desirable, and entertaining to hear about. ${ }^{34}$ In this way, his novel is not a conduct book at all, despite its origins, and Richardson's goal of creating a new non-romance-derived genre is realized.

Despite its flaws, the afterlife of Chapone's conduct book Letters has been vibrant, probably because of her eventual status as a Bluestocking. ${ }^{35}$ Hester Chapone's work, including her Letters on Filial Obedience (taken from her letters to Samuel Richardson about the plot of Clarissa) was widely read and incredibly popular in her own time. It was one of the four most-reprinted conduct books, and was bound with others, to create anthologies of conduct literature, that included the likes of Dr. Gregory (who will be discussed in detail in a later chapter of this dissertation) (Straight 316). Her Letters on the Improvement of the Mind went through three editions by 1774, and Queen Charlotte so admired the work in 1778 that she brought her daughter to meet Chapone. Even Mary

\footnotetext{
34 "Pamela whose unrelenting morality has to be seen as a vigorous attempt to reform the romance novel" (Mudge 70).

35 William St Clair notes that by 1800, Chapone's work became available "cheaply as one of the old-canon classics, and more than 22,000 texts were printed between 1800-1819 (592).
} 
Wollstonecraft mentions her with respect in her Vindication of the Rights of Woman, though unafraid to vilify other conduct-book writers like Gregory and Fordyce (Straight 326).

A big selling point for Chapone's work was not just its clarity, but the fact that the author herself was respected. Julie Straight says that despite the problematic status of a female author, Chapone's conduct and her Christian faith didn't suffer "in the slightest" from her ventures, making her a "viable role model for women who might want to investigate religious questions but did not want to suffer social ostracism or eternal damnation" (326). In my next chapter, that issue will take the forefront. What happens when the voice of authority in the conduct book is so suspect, that it is compromised by a lapse into sin or vice? What happens when the reality of the conduct book writer is so subjective? The conduct book, and the epistolary novel work in a different relationship, when the relationships they depict are fractured along the fault-lines of virtue. 
Chapter 2: Conducted to Anxiety: Frances Burney's Evelina and Sarah Pennington's An Unfortunate Mother's Advice to her Absent Daughters

Introduction:

What happens if the virtue of a conduct-book author is compromised? It is supposed to be a sign of winsome naiveté when the titular character of Frances Burney's Evelina (1778) writes to her guardian, "But, really, I think there ought to be a book of the laws and customs à-la-mode, presented to all young people upon their first introduction into public company" (84). It seems unbelievable, however, that the well-educated Evelina, raised by the Reverend Villars, has never seen or heard of a conduct book. Perhaps she might have read a copy of Fordyce's Sermons of 1766, considering her guardian is a clergyman? Nevertheless, a young ingénue like Evelina was certainly accustomed to hearing paternalistic voices telling her how to behave. Of course, there probably wouldn't be a copy of Sarah Pennington's An Unfortunate Mother's Advice to her Absent Daughters of 1761 around Evelina's house, because Pennington was in such a scandalous position when she wrote it. ${ }^{36}$ As Evelina's narrative proves, she is lacking in positive female, maternal role models. But her guardian would not allow Pennington, as the voice of a sinful mother, to fill that void. After all, the consequences of Evelina reading a book about a wayward woman might have led to a completely different novel.

\footnotetext{
36 Though not nearly as popular as Hester Chapone's work (which had 22,000 copies printed between 18001819, Pennington, had a long print-run, past the French Revolution (St Clair 275, 592). Hester Chapone's Letters and Pennington's Advice were occasionally printed and bound together, perhaps to increase Pennington's respectability as a writer, or to allow the reader an excuse to forget, or not learn the details of the provenance of Pennington's Advice.
} 
Both Pennington and Burney dramatize the consequences of an absent mother and reveal the anxiety present in all conduct literature: that the advice presented therein will be misinterpreted and misapplied with disastrous consequences. Though Evelina is a true novel, not a conduct-book-turned-novel like Richardson's Pamela, it provides comments on conduct literature by indirectly referencing conduct and walking through the narrative with a protagonist who must learn how to behave well in public, so it contains many elements of a conduct book.

Evelina is only now feeling this lack in her education (and complaining to her guardian) at the point in the novel when she has been thrust out into polite society alone, after her rather sequestered upbringing. Her mother died when she was a baby, and her only contact with the father-figure who raised her is now in the letters that form the epistolary novel. (In lieu of a parent, conduct books can take on that parental voice, in loco parentis when they can advise their readers on how to behave, and what to do in extenuating circumstances.) More to the point, there is no maternal figure available to show Evelina what good conduct looks like, so she relies on what her guardians and the recipients of her letters can tell her in their textual advice. Using the letters of Evelina and Sarah Pennington's An Unfortunate Mother's Advice to her Absent Daughters and analyzing the choices and distinctions that each letter-writer makes, this chapter will show that reading into conduct books the voice of a parent is still ineffectual. Pennington stimulates the reader's love of drama by her very omissions of physical details of transgression so that the reader is experiencing half advice-manual and half a generalized chronique scandaleuse. Her absence has made her stories into public matter, and the reader still has the choice of what they want to receive from the conduct book: the dramatic story of sexual sin, or the 
advice on how to avoid it. In the end, the mother has no power over how her advice is perceived because it is read and not given.

Perhaps Pennington's voice (so like Lady Belmont's letter to her estranged husband) would have been a better voice for Evelina to heed, but since Evelina is merely a character in a novel, there is no need for her to experience the brutal reality of Pennington's situation for herself in order to atone for her mother's sins. She can simply be granted her long sought-for legitimacy of birth and be disposed of in marriage. Unlike many staid, respectable conduct books of mid-eighteenth century (such as Fordyce's Sermons) Pennington's Advice engages with the world in a particularly anxious way, because it was written with that hint of scandal. ${ }^{37}$ The transfer of advice comes with hints of Pennington's own bad behavior, tantalizing the reader's expectations of drama, while still adhering to the format and genre of the Conduct-Book-as Open-Letter, and still vague enough for public consumption. Her daughters, the anticipated readers, are a silent audience, and we as fellow readers will never know how they interpreted or judged their mother's advice. (After all, how can a real daughter trust a compromised maternal voice which has sinned so grievously as to be shut out from respectable society?) But all conduct books anticipate a silent audience that will ideally follow the advice to the letter. Frances Burney's novel also anticipates that, and it "plays" or reads to that expectation, however unrealistic it is in both genres.

\footnotetext{
37 Pennington lost both custody and contact with her daughters after her marriage imploded, so she writes in her introduction that she has no recourse but to advise her daughters in a series of open letter, on how to behave out in society, and then privately in courtship and in marriage. Having vacated her physical place in her daughters' lives, she could only fill it with text.
} 
The cessation of the letters from Evelina to the Reverend Villars is caused by their assumed reunion after Evelina's marriage, so the epistolary fairy tale ${ }^{38}$ can have successful, happy ending, only after the heroine's epistolary presence has ceased to manifest. Sarah Pennington would like to get the same happy resolution of conflict between her and her daughters seeks to legitimize her own behavior, and her own ethos in the writing of her Advice, but the genre of the conduct book epistle is against her. Pennington's letters, sent to an audience who cannot respond, makes unproven claims that cannot lead to a happy ending full of a rehabilitated reputation. Looking at the works of Burney and Pennington together shows written instruction is not adequate as a mothering tool, since the expectations of the reader are set up for failure.

\section{Literary Review:}

While her work pre-dates the rest of my literary review, it's important to recognize Joyce Hemlow's 1950 article "Fanny Burney and the Courtesy Books" which paraphrased the name of Pennington's work to simply, "A Mother's Advice to her Absent Daughters" when grouping it with the works of Clara Reeve, and of the Reverend Fordyce (Hemlow 735). For this seminal piece of criticism that cites the work of the conduct book's influence on Burney's writing, Hemlow glosses over the perhaps tragic backstory, or impetus of Pennington's writing until a later citation, and only then to mention how Hester Chapone and Sarah Pennington's works were occasionally bound together as part of an advice compendium for young women (Hemlow 740). So, little is still known about Pennington's

\footnotetext{
38 More so even than Pamela, the story of Evelina becomes Perrault's "Cinderilla" down to an elderly "godmother" in the form of Madame Duval, whose machinations, however unsubtle, help the heroine to marry her "prince" (Perrault 64).
} 
indiscretion that it was clearly assumed to be truly salacious and needed the buffering of more "respectable" authors, at least at first, to grant Pennington some more respectable protection and legitimacy.

Contemporary literary criticism of Frances Burney's Evelina ${ }^{39}$ tends to fall into four categories. There are discussions of literary strategy and narrativity, as writers respond to Catherine Gallagher's 1994 Nobody's Story by discussing the fact that Evelina was published anonymously, and yet has such a clear narrative voice. Mark Vareschi's “Motive, Intention, Anonymity and Evelina" of 2015, Peter DeGabriele's "The Legal Fiction and Epistolary Form” of 2014, Guyonne Leduc's. "The dramatic import of letters" of 2014, and Christina Davidson's “To Speak As Others Speak" of 2016 are all examples of this category of criticism, since they focus on dramatized voices and intentionality.

There are articles which analyze aesthetics in Evelina, and Burney's definition of the beautiful, which fall into my second category of criticism. Melissa Pino's “Burney's Evelina and Aesthetics in Action" of 2010, and G. Gabrielle Starr's "Burney, Ovid, and the Value of the Beautiful" of 2011 are two examples of articles written in this category. Evelina is depicted as a beautiful girl, and literary critics also analyze the ways in which superficial beauty is tied to morality, and how Burney can use that which is beautiful to create social commentary, and to merge what is beautiful with what is considered good, the way that fairy tales often do.

\footnotetext{
39 There is little written in the last decade on Sarah Pennington, so this literary review will mostly focus on Frances Burney's work.
} 
Other articles discuss the role of sentiment, feeling and performative shame in the works of Frances Burney generally, and in Evelina specifically. Yih-Dau Wu's “'I Suppose It Is Not Sentimental Enough" of 2015 postulates that for Burney, the virtue of feeling lies in its ability to cement interpersonal connections that will last. Marcie Frank's “Frances Burney's Theatricality" of 2015 notes, "where we find scenes of shame in Burney, there we also find theatricality” (619). James Evans' “Evelina, the Rustic Girls” published in 2011 observes Evelina's delicacy being threatened by several comic characters, just like in a theatrical comedy of the same time period. The drama of sentimentality is perhaps the most common theme being analyzed in Evelina in recent years.

Lastly, critics have looked at alterity and difference in articles that provide a close reading of the dénouement scene of Evelina, when a monkey attacks Mr. Lovel. Laura Brown writes about it in her 2009 article, “Shock Effect: Evelina's Monkey and the Marriage Plot," and Susan Greenfield has written on this topic repeatedly, including her 2009 article, ““Monkeying Around in Evelina: Identity and Resemblance Again” Laura Brown's article argues that the monkey who appears in the final act of the novel is not there for just comic relief, but also problematizes issues of intimacy and difference in the eighteenth-century imagination (379-380). ${ }^{40}$ Brown delves into other similar monkey examples in theatrical scenes, and even from scientific books on human and animal anatomy.

Susan Greenfield uses her article to revisit issues of identity and doubling in Burney's Evelina that she first explored in her dissertation, and in her book Mothering

\footnotetext{
${ }^{40}$ As with many romantic stories in the comedy of manners genre, it is excessive intimacy, of characters being placed too close to each other, that creates the physical comedy.
} 
Daughters: and the Politics of Family Romance, Frances Burney to Jane Austen in 2002. She quotes Laura Brown's article and Patricia L. Hamilton's “Monkey Business: Lord Orville and the Limits of Politeness in Frances Burney's Evelina," of 2007. The novel Evelina, for Greenfield, becomes a test-case for defining the boundaries of what is considered human (421). Greenfield also speaks to issues of shame and embarrassment, which characterize many scenes in the novel, but also characterize the fact of biological kinship for Evelina as she embarks on her journey to explore the social world.

Looking at the recent literary criticism of Evelina shows that the themes of voice, intention, narrativity, shame, and identity are still at the crux of our understanding of Burney's first novel. Pairing Evelina with Sarah Pennington ${ }^{41}$ highlights the same themes playing out in An Unfortunate Mother's Advice: Pennington's voice, her intentions, her unreliable narrator that begs to be seen as trustworthy, her shame, and her very identity as an "Unfortunate Mother" remain ambiguous throughout her Advice. Both the novel and the conduct book are consciously assuming that the material text of written advice can substitute for the word of the mother, but both texts show only compromised maternal presences, cut short by scandal, or death, or both.

\section{Sarah Pennington's Life and Work:}

Little is really known about how Sarah Pennington socially transgressed so far as to be a scandalously divorced woman who lost custody of her children. All her four publications are semi-autobiographical in nature, dealing with the shame of her disgrace.

\footnotetext{
41 The fact that critics have not focused on Pennington is incongruent with the publication history of her Advice, which according to William St Clair had an "extraordinarily long print run for its reprints (275).
} 
Most of what the reader must rely on in her Unfortunate Mother's Advice, is her defense of herself, which is not always successful, considering that it is merely the point of view that Pennington wishes to display. Her Advice begins by warning her daughter that she is entering into, "a World full of Deceit and Falshood, where few Persons or Things appear as they really are" (Pennington 10). Pennington must begin with this bitter truth, to attempt to fend off her reader's judgments, but she cannot read her work for them. She cannot avoid the contradiction inherent in her claim: if the entire world is full of false characters, and she has already sinned, why should she be trusted?

Sparing the reader/daughter the long story of her numerous vices (which might have been tempting or titillating) Pennington reverses expectations by asserting that my private Conduct, was what the severest Prude could not condemn; my public, such as the most finished Coquet alone would have ventured upon; the latter only could be known to the World, and consequently, from these must their Opinion be taken, which, you will easily see, could not be favourable to me, but, on the contrary, gave a general Prejudice, that has since been made an Argument to gain Credit for the malicious Falshoods laid to my charge (5).

Pennington is referencing the fact that she might not be a particularly bad person, but she is performing the part of one in the public eye. While her present situation is sad, she looks forward to the time when, "by ripening your Understanding," her children will be ready to hear her story (Pennington 5). In the meantime, she instructs her daughter to "remove other prejudices from [her mind,] and at that time, the daughter will "be informed of the whole Truth without Disguise or Partiality" (Pennington 9). While that time brings relief to Pennington's mind, at the same time she pleads with her young daughter to "suspend [her] 
Belief of all that may have reached your Ears with regard to [her mother] and wait for the Knowledge of those Facts a future letter [sic] will reveal for [her] information," a letter that contemporary readers have never seen (Pennington 9).

Readers might feel frustrated by the fact that Pennington is unwilling to disclose this information, because Pennington is teasing her readers with her vagueness. Eighteenthcentury women writers were considering their audience as women like them (as Nancy Armstrong proved) and it's clear that Pennington's desired audience is young women, specifically her daughters, for the purpose of their instruction. But since Pennington is matter-of-factly directing her letters to her daughters, while at the same time compelled by forces other than the literary marketplace (like her maternal impulses) Pennington might not fit exactly into Armstrong's ideas of the domestic women's writing. She also isn't writing a novel. 42

Pennington claims that the method of communicating to her daughters in an open letter is the "least eligible Method of contacting them (Pennington 1-2). After all, their family matters are not public business: "The Public is no way concerned in Family Affairs, nor ought to be made a Party in them; but my Circumstances are such, as lay me under a Necessity of either communicating my Sentiments to the World, or concealing them from

\footnotetext{
42 For more information on the conventional structure of a conduct book, see Nancy Armstrong's Desire and Domestic Fiction: A Political History of the Novel (60) and Marilyn Francus's article, “Tis Better to Give: The Conduct Manual as Gift" in The Culture of the Gift in Eighteenth-Century England, edited by Linda Zionkowski and Cynthia Klekar (80).
} 
you; the latter would, I think, be the Breach of an indispensible Duty, which obliges me to have the impropriety of the former" (Pennington 2).

After her trying to justify the rationale behind this public forum, readers might expect an explanation of why her exigent circumstances have created this battle in her soul between maternal duty, social duty, and the disclosure of indecency. However, Pennington refrains from telling her daughter the specific details of how her reputation was destroyed so completely, simply asserting that it happened before her daughter would be old enough to "form any right Judgment of her [mother's] Conduct, and since that Time it is very probably that it has been represented to [her daughter] in the most unfavourable Light" (Pennington 2). She is self-censoring for the sake of her daughters' integrity, which can be perceived as a completely proper maternal instinct. Or, it's the author being coy for the sake of her readership. Pennington wishes to separate her maternal authority from her implied transgressions. This shows her text to be hypocritical. It is ambiguous whether or not she is saving her daughter's reputation, or her own. ${ }^{43}$ Pennington does not write her Advice as a confessional, rather she wants to have it both ways: piquing the reader's curiosity and then refusing to deliver. She takes the stance that if she had been more mindful of how people judged women's behavior, her own moral fall from grace could have been avoided.

Sarah Pennington has no trouble teasing her reader for more perhaps more interesting details regarding her reputation, but she is also committed to writing an open

\footnotetext{
${ }^{43}$ For more definitions of hypocrisy, see Jenny Davidson's Davidson, Jenny. Hypocrisy and the Politics of Politeness: Manner and Morals from Locke to Austen of 2004.
} 
letter full of advice, so the instability of the genre that she is writing in, is mostly of her own making. By internalizing, or repressing her story, she is giving it more power. Readers are left asking the question: what, in such a rigidly patriarchal society that places such an emphasis on the role of domestic femininity, could a woman do to deprive her of custody of her own children? It must have been something truly dreadful for that to occur. ${ }^{44}$

Despite inconsistencies within her writerly persona, Pennington urges her daughter to always remember that "next to the Consciousness of acting Right, the Public Voice should be regarded, and to endeavor, by a prudent Behaviour, (even in the most trifling Instances) to secure it in [her daughter's] Favour" and reifies the definition of hypocrisy for her children: advising them to attend to the public face, no matter what the private one may look like (Pennington 2). The reason that Pennington had gone wrong, she says, was that she was never taught that rule. She was simply taught that by the inner cultivation of virtue in her private life she would remain virtuous, and still avoid appearing inconsistent, or hypocritical. For Pennington, to be an adult means to be a hypocrite, and to abide by society's rules as to what publicly appears to be virtuous. The "Consciousness of acting Right" is actually the most important aspect of morality, more than a good reputation.

A mother's advice can be given in the private sphere must be exhibited publicly in order to forge a reputation, and Sarah Pennington tells the reader she is all too aware of this forging. The open letter is especially suited for both public and private aims, in that it is personal, private, and domestic, and yet repurposed for the public's ends. ${ }^{45}$ However,

\footnotetext{
${ }^{44}$ Lawrence Stone wrote the foremost guide to understanding marital and divorce law in Great Britain in his 1990 book, Road to Divorce: England, 1530-1987.

${ }^{45}$ See Michael McKeon's The Secret History of Domesticity: Public, Private and the Division of Knowledge, 2005.
} 
Pennington's public reputation, so destroyed, was only textually restored in her Letters; Burney's happy ending to Evelina's "Cinderella story" can be a more complete rehabilitation of reputation and character for Caroline Evelyn, and her daughter Evelina Belmont. The novel as a genre necessitates the creation of a whole character, with fewer contradictions for the reader to parse in order to understand the character's motivations.

\section{Frances Burney's Posturing and Writings:}

Obviously, Frances Burney's anxieties regarding publication have been well documented. In 1767-the same year that her father remarried, after her beloved mother's death and her own loss of that gentle maternal voice to guide her-she burned all her juvenilia, including The History of Caroline Evelyn (Jones xl). Historians know that Burney and her siblings didn't exactly care for their new mother, to whom they privately ascribed the title of the "Evil Stepmother," like in a fairy tale. But scholar Margaret Anne Doody notes a more problematic paradigm in the Burney family. The fawning and obsequious behavior Mr. Burney-Frances's father-affected in public to garner patronage was particularly unsettling for Frances and conflicted with her own desire for publicity and fame. Frances was cautious regarding the publication of any of her work, to avoid that "unladylike exposure" which would have scandalized all the relatives.

Luckily, Burney was not guilty of any sexual misconduct, and reputation protected. Even though novels were the eighteenth-century equivalent of cotton candy, Burney saw their value, and sought as many other eighteenth century women-writers did, to validate these "trifling production of a few idle hours" on every page that she wrote. She seeks the "protection" of the reviewers in her opening letter to the work, saying how they were all 
young writers, starting out at one time, and might fear their reviewer (Burney 6). Burney does plead for mercy, (even quoting Shakespeare's famous speech in The Merchant of Venice's on Mercy) but in truth she does not need such protection to make her work successful (Burney 6).

Burney presents herself to her readers, with a "very singular mixture of timidity and confidence" (9). By claiming both of these contradictory postures, Burney herself understood the act of writing a text to be as unstable and contradictory as the act of reading it. Like Pennington's style of disclosure through non-disclosure, Burney performs reluctance publicity for the sake of keeping her reader's interest, even though these behaviors might be at odds with a "moral" or a gesture towards virtuous behavior.

Frances Burney's Evelina shows the progression that Pennington's daughters will experience, from girl to woman, through a conventional bildungsroman. To further that point, both texts are contingent upon the physically absent (but verbally present) maternal voice. ${ }^{46}$ Readers sympathize with Evelina, as she struggles through the epistolary novel looking for the place in the world where she belongs. Evelina's face is apparently the replica of the face of her dead mother, Caroline Evelyn, ${ }^{47}$ but that physical body is not the same as the mother's body and is different again from the body of text that gives evidence of Caroline's tragic story, and how she was wronged by Sir John Belmont, Evelina's father.

\footnotetext{
46 The same way that the German version of Cinderella features the dead mother speaking through the leaves of a tree over her grave, from which Cinderella gets advice and magical objects are dropped down to her, to help her attract the attention of the prince. However, Grimm's Fairy Tales were popularized in print in the early nineteenth-century, while Perrault's version of the story was probably more accessible to eighteenth century audiences, and the tree is not featured in the French version.

${ }^{47}$ See Susan Greenfield's "Oh Dear Resemblance of Thy Murdered Mother": Female Authorship in Evelina" of 1991.
} 
The narrative of Evelina could not have occurred (or at least the happy romantic-comedy ending could not have) if Evelina had not so closely resembled her mother. ${ }^{48}$ Evelina's visage cannot bring back the dead or change the tragic circumstances of Evelina's birth. But by using Caroline's face as both a mask that reveals only her beauty and a signifier of her legitimacy when she finally encounters her biological father, Evelina can successfully navigate the public life of London, and finally to step out from her mother's shadow to become a woman of the world. Sarah Pennington's daughters must make the same movement that Evelina does, but on a real public stage with no romanticized foregone conclusion to anchor them, only their mother's literary strictures. ${ }^{49}$

\section{An (Anxious) Mother's Unfortunate Advice:}

The reader is led to understand that Sarah Pennington was young, and inexperienced in social etiquette, like Evelina's situation at the beginning of Burney's novel. Unlike Evelina, however, Pennington was not chaperoned. Most married women were no longer thought to need the chaperoning of others, but instead were supposed to be the modest, discrete chaperones for their female friends. ${ }^{50}$ That is why Pennington, "took a foolish Pleasure in exceeding" the bounds of prudence in her own behavior, and the sexual double-standard for her behavior continues to punish her as she writes her letters without getting to be with her daughters. When Pennington advises her daughters as to how to

\footnotetext{
${ }^{48}$ Kristina Straub quotes Anthea Zeman, calling the story of Evelina, "Cinderella demystified" in Divided Fictions: Fanny Burney and Feminine Strategy of 1987 (Straub 1).

${ }^{49}$ Perrault's fairy tale morals are able to wrap up each of the stories with clever little ditties that hammer home exactly what the reader is supposed to take away from the story, including, in the "Cinderilla" case, the benefit of having good "Godsires" or godparents (74).

${ }^{50}$ See Lydia Bennet's desire to escort all her sisters around to the "balls" and assemblies in Pride and Prejudice, after she is married (Austen 39).
} 
behave in public, it might be considered inconsistent compared to how she behaved herself, or at least that is what the reader assumes. The reader's expectations continue to be confounded by Pennington's gestures to her natural instincts as a mother to preserve the innocence of her children, and her rhetorical submission to the higher powers that will eventually vindicate her behavior and find her faultless.

Readers are meant to see Pennington as completely reformed from her sinful youth. She is full of upright Christian faith and patience. As her daughters approach adulthood, Pennington claims to them, if, “Religion has any Power on [your father's] Heart, I make no doubt, he will then acquit me to his Children" (Pennington 7). Pennington offers a passive aggressive suggestion to her former husband, to not poison his daughters' relationship with their mother while attempting to lead her reader towards who can judge her behavior (i.e., no one except God). Of course, Pennington's readers must follow her rhetorical example, and believe that Mr. Joseph Pennington is capable of real Christian charity. Otherwise the happy reconciliation between Sarah Pennington and her daughters cannot take place, unless Pennington is attempting to publicly shame her former husband in a public forum for not behaving as he ought to his daughters and to his ex-wife. Pennington would like to have her character's point of view be the only point of view her readers can see. However, her gestures towards her ex-husband's virtues have no real authority behind them, since she has not told the readers how their marriage ended. Her daughters might know, but they might not. Pennington continues to use vague generalizations to amplify her own character, but this rhetorical strategy has too much room in it for a reader to see her in a completely different way. Regardless of Pennington's intent to appear virtuous in her 
Advice, if readers are curious about the inter-marital conflict, and wish to get more hints to paint a clearer picture, they will inevitably read on.

In a self-conscious way, Pennington is eager to assure her daughters of her own reputation. But because she is so self-conscious of what she is presenting, the readers are aware that we are only hearing one side of the story: Pennington's. Pennington depicts a fairy tale ideal husband for her daughters to aspire to, while still calling attention to the terrible character of a "Libertine" (Pennington 51). We as readers learn from Pennington that an ideal husband should be a friend as well as a lover (Pennington 52). Of course, by this point in the conduct book, the reader understands no such fairy tale existed for Sarah Pennington. Frances Burney will use the same dramatic elements of a poor female's posturing to set up Evelina's backstory, and make the reader see her upward rise to social legitimacy as justified. Then, Lady Belmont's letter to her husband will absolve the same Libertine-character, Sir John Belmont, through the dramatic emotional appeals that he makes in his theatrical reunion with his true daughter. ${ }^{51}$

\section{Caroline Evelyn's Letter, and Insufficient Surrogacy:}

The one letter that is written by the dying Caroline Evelyn Belmont has a prominent place in the narrative of Evelina, as our protagonist keeps it on her person throughout the novel, and only reveals it dramatically to her father who realizes, in a truly fairy tale twist, that his ward and Evelina were switched at birth, and he has been supporting the wrong

\footnotetext{
${ }^{51}$ For detailed analyses of the dramatic reunion between father and daughter in Evelina, see Peter DeGabriele's "The Legal Fiction and Epistolary Form: Frances Burney's Evelina" of 2014, and Marcie Frank's "Frances Burney's Theatricality" of 2015.
} 
daughter for years (Burney 374). ${ }^{52}$ In the letter's melodramatic prose, the dying Lady Belmont appeals to her estranged husband, "in behalf of the child" who will bear the letter to her father (Burney 338). Though she has had no effect previously in appealing to her husband, Lady Belmont continually strives to make the connection between them on the page. While this letter is not an example of conduct literature, it relies on archetypical characterizations of right and wrong to prove Lady Belmont's points. It is her feelings as a mother, a mother, "agonizing for the fate of her child" that impel the written pleas (Burney 338). Her final intercession to Sir Belmont is to validate her daughter Evelina's birthright, though he will not validate his own marriage.

Here, Lady Belmont's instincts are shown to be the most maternal. She claims that she wants nothing but for her child to be safe and protected. Readers know that with that safety and protection will come property and socioeconomic status, but Caroline's letter does not dwell on those implications. Knowing that she is dying allows to her to appear as the purest maternal voice that only wishes for her daughter's life to be better than the one she is departing. Readers know that Sir Belmont burned their marriage certificate, and pretends that the marriage never happened, in the process morally ruining his wife and casting his daughter as illegitimate. Lady Belmont's pleas are set up as empathic and beneficent compared to Sir Belmont's callous apathy. However, the reader is still unsure of whose reputation will be better saved: the mother or the daughter.

\footnotetext{
${ }^{52}$ Charles Perrault's "Cinderella" also focuses on the physical aspects of Cinderella's beauty as echoing her dead mother so exactly, that it is the reason her stepmother and stepsisters immediately begin to punish her as soon as Cinderella's father marries the stepmother (59).
} 
In despair, Lady Belmont wishes that the child, "look not like thy unfortunate mother" so that Sir John Belmont will not cast her aside, the way that he cast aside Caroline (Burney 339). Lady Belmont wishes for her daughter to avoid the stains of scandal that her own beauty caused her. She will not get her wish of course, but it's important to note that to the very end, she believed that her husband hated her, and ardently wished that her daughter would avoid the same fate. Evelina's beauty is a double-edged sword insofar as it will provide her with options on the marriage market even before she is granted legitimacy, but along with that, will garner her emotional estrangement. ${ }^{33}$ Lady Belmont understands what it would be like for her daughter to be raised under the shadow of illegitimacy, and how the world would look down on her, so she makes a dramatic overture to her estranged husband on behalf of her daughter. In many ways, the motives of Sarah Pennington and Lady Belmont are the same. They speak with the similar urgency in their letters, an urgency that occasionally is evidence that advice, or conduct literature is being written, though Lady Belmont is not attempting to write a conduct book.

Lady Belmont's entire history is known to the reader at this point in the narrative, and she did not write the letter for publication, but instead as a private plea to her spouse. She can be franker, more despairing, and not posture as much for the sake of respectability and decency, but she is seeking a respectable reputation for her daughter, so the boundary

\footnotetext{
53 Critics have also noted that Sir Belmont does not appear until the final act of Evelina, and even then, not for very long (see DeGabriele). Perhaps the rakish Sir John might be worried he will harbor incestuous feelings towards his own daughter, since she appears as the living replica of her dead mother. In Perrault's fairy tale, the very common instance of the father remarrying after the death of his wife, and bringing conflict into the home in the form of his second wife, who, "governed [the father] entirely" (Perrault 59). Burney would have understood this dynamic as well as Perrault, since her own father had done the same thing to her family (see Doody). Marina Warner looks at the elements of warning present in some of the Chinese and German retellings of Cinderella: a warning to second wives not to mistreat their stepchildren (212-214).
} 
between public and private still seems permeable, similar to Burney's herself. ${ }^{54}$ Lady Belmont doesn't need to censor her letters to prove that she is anything other than Sir Belmont's wife, which she repeats frequently, but her assertion is that she is doing is what any mother would do. Caroline's circumstances have proved her situation to be desperate, but since there is no other option, so will write with her whole heart. Her daughter Evelina will have more recourse, and more resources than Sarah Pennington did as she matures, practicing and learning discretion and more protected as she sees how to survive out in the world. However, there is still ambiguity as to whose reputation is being salvaged: Caroline's or Evelina's.

\section{Evelina the Unreliable Censor:}

The heroine Evelina has a keen attention to detail (and seems to have absorbed Burney's love of drama and the theatrical). The first part of her narrative seems to consist of her watching, and inevitably mocking the ridiculous social stratagems that seem to be constantly in motion around her. Evelina laughs during her first ball at the absurdly foppish behavior of Mr. Lovel, in fact she, "could not help laughing, which [she] fear[ed] encouraged him even more (Burney 43). However, the more that Evelina learns, the less she laughs. ${ }^{5}$ The more she is aware of the social machinations that are working to push her towards her inevitable marriage plot, the more she is inclined towards sarcasm, embarrassment, and even pain, just as her guardian Rev. Villars has feared, (though what she experiences are

\footnotetext{
54 Burney constructs a domestic novel (a novel about private, familial concerns) for public consumption.

55 Gina Barreca talks about the danger of a woman laughing or knowing that she "gets" a joke when she talks about "good girls" and "bad girls" and the nature of female desire, in They Used to Call Me Snow White, But I Drifted of 2013. For Barreca, as for almost all Judeo-Christian writers, sexual knowledge is seen as a deviant.
} 
developmental adjustments, that are more akin to growing pains, as she begins to see the overwhelmingly superficial side of public life).

The inherent duplicity in having to perform a social role, while internalizing private thoughts and feelings, have also made it possible for Evelina to play a part for her guardian, or at least to acknowledge that she can play a part, and commits for this "first woman" 56 the sin of omission. As much as good conduct, good behavior, performance, and acting a part is a critical part of conduct literature for women, it is also part of human development. In Evelina's case, her fate on the Marriage Market will be determined by her choices as she learns how to behave. For Evelina, the journey from innocence to experience is not categorized by a sexual fall, it's simply a growth of understanding built on experience. As readers, we are taught that Evelina is too pure to be caught up in any sexual or moral depravity. But the world is a sinister place that she must struggle to understand, and it is her difficulties navigating a multitude of embarrassments, and threats that create the myriad of conflicts she must wade through to find wisdom, without her mother's guidance or leadership.

In the writing of her first letters, Evelina does not discipline her responses to her guardian. But the wiser Evelina formulates her letters based on her reader/Guardian's expectations. Early on, the reader meets Captain Mirvan, the vulgar sailor who is married to Mrs. Mirvan (a true gentlewoman). In one of her honestly outraged moments, Evelina wonders at their marriage, telling Mr. Villars, that Mrs. Mirvan, "deserved a better lot. I am amazed she would marry him" (Burney 40). This note of inconsistency, that a woman might

\footnotetext{
56 Many literary critics have noted the similarity in Evelina's name to the biblical "Eve."
} 
marry for any reason that was not love, is what the rest of Burney's narrative attempts to smooth over (though it's impossible to resolve the discord that Captain Mirvan brings to any situation or dialogue).

Where Captain Mirvan's opinions and Evelina's diverge is in their gendered judgments. Even Mr. Villars agrees with a few of Captain Mirvan's opinions, especially regarding London, "and its manners, inhabitants, and diversions" is much "upon a level" with Captain Mirvan. (Burney 117). This is as painful to Villars as it is useful for Evelina to know, when Villars considers that as a man, Captain Mirvan has the power of chaperone and father figure over his beloved ward. Evelina can find Captain Mirvan an affront to everything delicate, feminine and sensible, but the Reverend Villars sees merit in his strength as a man, and his ability to (theoretically) protect his child. Evelina won't bestow such frank judgments at the end of her tale: she has learned to only share what her guardian wants to know.

All the way through the novel, Burney is very clear with whom we should be allied in Evelina's letters, and uses Evelina's talents as a mimic to hammer these ideas home. At the same time, this biting humor that Evelina employs shows that she herself has been deprived of the company and socialization that a maternal role model might have provided, to the point that she resorts to snobby cattiness to describe her own discomfort. And much of the novel is about social discomfort: embarrassment about vulgar relatives, or one's own behavior, or one's own lack of control or agency regarding her own body, when it blushes, flushes, or is in the physical power of someone else. How many times does Evelina defend her decisions in her letters to Mr. Villars, asking him to consider how she can best "avoid 
immediate humiliation" (Burney 95)? Mr. Villars has no real answer for her, other than that she should return home to him at Berry Hill immediately. He and the reader share Evelina's vicarious embarrassment for her many social errors, in front of Lord Orville.

Evelina's first encounters with Lord Orville are tinged with embarrassment and "confusion" at his behavior, and her own (Burney 37). She isn't that happy to see him, when she does, because it seems that his noticing of her is worse than all the social calumny that she might otherwise be experiencing with her vulgar relatives. It is all shame and blushing and embarrassment, until she tells her guardian that she wishes he knew Lord Orville, because his benevolent behavior has so recommended him that she wants to offer a form of justification as to why she is perplexed and embarrassed by his notice. But after listing out his many gifts, she starts the process of self-censoring, telling the Reverend Villars, that she "must not expatiate upon this subject." (Burney 74). After the Reverend Villars praises Lord Orville to Evelina in responding letter, she is relieved, and marks his approbation with the initial fear that her account of him would be "weak and imperfect" (Burney 118). Evelina knows that the way to make her guardian happy is to deprecate her own abilities, and she doesn't want to worry him, by dwelling on how much she thinks of Lord Orville. Reverend Villars becomes the voice of the staid, respectable paternal guardian. Evelina has internalized his panoptical parental authority, instead of resisting it. Like perhaps the most famous conduct book writer, the Reverend Fordyce in Fordyce's Sermons (who will be discussed in the next chapter) Reverend Villars always knows what's best for his female charge and has no qualms with enforcing his rhetorical authority on his unmarried ward. Evelina appears subsumed by this authority upon a first reading of her letters to her 
Guardian, until the reader realizes how much she is writing about Lord Orville or writing about not writing about Lord Orville.

As the novel reaches its conclusion, Lord Orville's star is rising in Evelina's consciousness, and Mr. Villar's star is falling. Even though Villars can read Evelina's letters, and know that her increased levels of understanding have resulted in increased levels of self-censoring, he avowedly knows that he lacks the power to influence Evelina's behavior, and must resign himself to the position of spectator. Villars, Fordyce, and all conduct book writers can only ever dispense their advice, they cannot make sure that it is interpreted, or even followed appropriately.

Late in the letters, Evelina sees herself through Lord Orville's eyes on occasion, which greatly increases her mortification and embarrassment (Jones xx). When discussing the possibility of initiating a lawsuit against Sir John Belmont to sue him for Evelina's paternity, Villars bemoans that he cannot do what he truly wants to, regarding Evelina's fate. He cannot "follow the dictates of [his] own heart," and "instantly recall [her] to [himself], and never more consent to [her] being separated from [him]," because the manners and opinion of the world demand a different form of conduct (Burney 130). He complains that he and Evelina are "slaves to custom" in the world they live in (Burney 166). In this instance, Mr. Villars takes the tone of Sarah Pennington, insofar as he sees the rules of society as trumping his own personal desire to take his daughter home to him, but the customs of society are disrupting that desire. Good conduct (like the kind that was innocently taught to Evelina during her secluded education at Berry Hill) can insulate a person from the world, and enable to move around in it, but it cannot make a person 
belong to it, or equip a person to play the games that are required to thrive in it. A good education in conduct is an inadequate surrogate compared to a mentor who can lead by example, showing the mentee how to exist in the world.

As Evelina goes out into society yet again, most of her descriptions of Lord Orville are plot summary: narrating where he was, who he was with, and only at the conclusion of each letter, saying how happy she is, and then how much she will miss Lord Orville. She compares him to her guardian repeatedly, as if to validate how noble and valiant he truly is. These chaste, noble descriptions continue through the revelation of Evelina's parentage, and the courtship of Orville and Evelina. In fact, the conclusion of the narrative is as rapid as it is sanitized. There is more volatile titillating drama in the swooning, story of Lord Belmont, and more blood and gore in the release of the monkey that bites Mr. Lovel than there is in the marriage plot of Evelina and Lord Orville, though it does arrive at its foregone, happy conclusion. Frances Burney uses these disruptive and violent scenes in contrast to the happy romantic ending to legitimize what Lord Orville and Evelina Belmont will have, after their success on the public marriage market. While their courtship is meant to depart from the conduct ideals of the Reverend Villars, the resolution of the story in a conventional marriage plot is the exact same outcome that conduct literature should be preparing a young girl for. More importantly, it is the only outcome that Lady Belmont could possibly wish for her daughter.

The maternal wishes, which transcend the public and the private, become the most important thing for Evelina, and the driving force behind her marriage, because her marriage with epitomize the public face of legitimacy that has been granted to her, and 
allow her to experience private domestic happiness with her beloved Lord Orville. Because Evelina began her story with no parental legitimacy or social standing, it is necessary to conclude her story with rapidity, as if her readers are the social public who must be convinced that Sir John's daughter is marrying well and must ignore the scandal that led to his mistaking his natural daughter's identity. Evelina must also be safely disposed of in marriage as quickly as possible to keep the reputation of Ms. Green intact as well. Since there is no mother to legitimize Evelina's biological place in the world, Burney can make her nuptials a vanishing point at which good conduct leads to its best conclusion, because the reader can then imagine the happiest most romantic outcome for the couple and relegate the conclusion of the novel to the world of fantasy.

\section{Conclusion:}

Women writers engage with advice on good conduct when they are despairing and forced to self-censor. Sarah Pennington omits salacious details of her own life to create her conduct book and gesture towards her maternal ideal that she cannot enact, because she lost custody of her children. Lady Belmont writes because she knows that she will die, and her daughter will have nothing by paternal voices in loco parentis to guide her, and they will not understand the female experience enough to truly protect her daughter. Evelina will struggle, but she will eventually thrive, despite the violent unpredictability of life. Not so in a conduct book, instead, Pennington's omissions can sound contradictory and even hypocritical. Juxtaposing Burney's novel with Pennington's conduct book reveals the dangers of the mis-reading of the texts but also in the mis-direction of the author. The marriage plot is in no way an inevitability for the reader of a conduct book. The fact that 
Pennington acts like it is makes her text hypocritical. The genre of the conduct book works against Pennington, and her silent reading daughters might never get their happy ending.

To add to the progression of a young girl to a woman throughout the novel, Evelina's abilities as a writer improve dramatically throughout the text. But that seems to really speak most to what Evelina becomes savvy enough to leave out of her tale (almost as if she is becoming more like Pennington and mastering the art of distraction and misdirection). Evelina clearly wants a romantic happy ending for herself, but she seeks legitimacy and validation from the people who have raised her as well, and by the end of the story she knows how to couch her desires in terms that her friends and guardians approve of. Evelina's story is the tale of Cinderella becoming self-conscious, aware of how she is perceived, and how damaging wrongful perceptions can be. Ever-mindful of those damaging perceptions, Pennington remains unapologetic in her desire to connect with her daughters. Aside from that almost primal need, she is apologetic in almost everything else, and glosses over huge parts of her narrative to establish her writerly ethos. The reader's curiosity about what has happened to Pennington can drive them forward, but they will be left unsatisfied by the book's end, because all that remains are vague strictures on good behavior, and lots of censoring.

To achieve their happy ending, both novel and conduct book must brighten dark truths. The pithy Charles Perrault "moral" at the end of the "Cinderilla" tale is that good "Grace, / Exceeds, by far, a handsome Face;" (73). But there is nothing in Perrault's story to prove that his "Cinderilla" would have been as fortunate, or as blessed, if she hadn't started out by being externally attractive. This optimism leaves readers feeling that they aren't 
hearing the whole story. In Pennington, the whole story is that this mother has experienced such a drastic fall from grace that the only contact she might ever have with her children is through a public missive, and she might never see them again. Her eternal legacy is a set of rhetorical postures that bend towards virtue. In Burney, the whole story is that Evelina is now married and legitimate and wealthy but is confined by those societal structures and the rules that will form all of her behavior for the rest of her life (Jones xii). Lady Belmont couldn't ask for more for her daughter than a good marriage, and Evelina's happiness in life, it is implied, will exceed her mother's. However, a good marriage was the only legacy that Lady Belmont could leave to her daughter. There were no other option.

Despite these differences, readers are on common ground when looking at the way that both authors choose what to reveal at any given moment. Both authors know in their mother's letters-Sarah Pennington's and Lady Belmont's—-that painting themselves as simply devoted maternal voices marks the inconsistency in these voices possess. Daughters of the eighteenth century had very few options in terms of hearing effective behavioral advice. Either their staid, respectable father-figures, like Reverend Villars (and later Reverend Fordyce) will be presenting themselves as completely out of touch, or the voice of their compromised mothers would reveal the stain of sexual sin. Inevitably these young ladies would be forced to contend with the inconsistency and ineffectiveness of all the advice they were getting and be forced to either silence themselves as they appeared to absorb it, or to co-opt the language of such advice and force it to work for their own rhetorical aims, in their own writings. 
The conduct-manual, even if written by a mother-figure, cannot serve as an adequate maternal surrogate. Even if Pennington could contact her daughters privately, would never serve as an adequate role-model because of her presumably scandalous past. The reason for the maternal absence is unstated, and therefore the reason is absent. But in a way, what is true of Pennington is more generally true of conduct-books written by mothers, and even more generally of all conduct-books. As readers, we crave the satisfaction of open communication: to fill in the blanks, and to create a biographical romance-narrative even if something else is nominally intended. The Reverend Fordyce provides the same temptation to the readers of his Sermons, and Jane Austen is all too aware of this in Pride and Prejudice. 
Chapter 3: Conducted to a Happy Ending: Jane Austen's Pride and Prejudice and James Fordyce's Sermons to Young Women

\section{Introduction:}

Will a conduct book ever create the perfect story? Jane Austen wrote novels primarily to entertain by dramatizing and judging the problems of her world, and Pride and Prejudice of 1813 is generally considered to be her most popular novel, and one of the most formally perfect narratives in the literary canon. James Fordyce wrote his Sermons to Young Women of 1766 for godly girls, giving them a perfected code of behavior, according to his standards. Yet his texts left himself open to parody and critique by Austen through the character of Mr. Collins, and the reactions of the Bennet sisters to his reading of the Sermons. Much has been written about the impact of Fordyce on Austen, ${ }^{57}$ but my critical inquiry will focus specifically on how Austen commandeers his tone, his religious language, and his ideas to create her narrative, all the while mocking and satirizing his project. ${ }^{58}$ In doing so, Austen's novel becomes a kind of conduct literature itself. Satire can work as a secularizing force, because it breaks apart the monolithic nature of religious belief with doubt and skepticism and, as I would argue, the structure of the narrative itself. The marriage plot of Mr. Darcy and Elizabeth Bennet can break apart the moral of a conduct book or erode it past the point of recognition very quickly (at least according to these anxious writers of conduct books, who feared the novel's appeal to non-intellectual senses).

\footnotetext{
57 See Katarznaa Bronk, Nancy Armstrong, Vivien Jones, Ingrid Tague, and Karen O’Brien for discussions of the cultural importance of Fordyce's Sermons in the eighteenth century.

58 Religious texts still outsold conduct manuals in the eighteenth century. Fordyce, apparently an excellent orator, went about the creation and the publication of the Sermons with the very public aim of promoting female religious rectitude (St. Clair 131, 459-479, 539, 551-571).
} 
The writers of eighteenth-century conduct books are eager to set up the binary between the good, moral, pure, safe religious world, and the evil, immoral, dangerous, world full of deadly temptations. We can look at secularity as in binary opposition to religiosity, but that definition does not always work for the purpose of understanding Austen's world, and the world of eighteenth-century England. Secularity, according to Charles Taylor, refers less to religion, and more to a plurality of ideas (43). It becomes a form of open-mindedness, and, in the broadest sense of the word, non-sectarian. Austen's style is one way that her novel works as a secularizing force, containing free indirect discourse that alternately aligns with her protagonist Elizabeth Bennet, and then veers away from her, as Elizabeth tries to figure out her authentic voice, and her place in the world. According to Taylor, "Secular reason is a language that everyone can speak and argue and be convinced in" (49). The irony is that the romantic language of Austen's novels is another language that everyone can also be convinced in. Austen uses Fordyce ironically and secularly, to create a new genre: the conduct-book-romance.

For the purposes of this dissertation, only Jane Austen provides a moment wherein a novel's characters are physically interacting with, and receiving the language of a conduct book. The scene of Mr. Collins, the boorish vicar, opening a book of Fordyce's Sermons to read to the young ladies in the evening, only to be interrupted by Lydia Bennet is meant to enhance the reader's understanding of both characters, and to find humor in the ridiculousness of the situation. We readers might chuckle, or groan internally at Mr. Collin's pedantic behavior but part of the humor of satire is that kernel of truth within: we might have responded to Mr. Collins in the same disrespectful way. If Mr. Collins had more powers of observation, he would have realized that the oldest Bennet daughters would not 
accept the overtures of marriage he would offer, because the daughters had read novels that included romantic notions of what they wanted from life. The readers' first impulse (or their first impression, as Pride and Prejudice was originally called) would be a dismissive attitude towards Fordyce, but as the novel progresses, many different characters utilize ideas, and absolutist moral code of Fordyce, if not his exact language. In co-opting of conduct book language for the purpose of satire, Austen enhances the drama and humor of the romantic plot. However, Austen also reveals the contradictory elements in the conduct genre, which were not designed to take the reader on a journey of self-discovery, but instead to ascribe a set of rules for human behavior. The novel by nature of its genre ${ }^{59}$ can promote uneven story-telling, and Fordyce's language actually recreates Austen's novel as a new species of conduct literature tied together with the promise of romance.

\section{Literary Review:}

Literary analysis of Fordyce's ${ }^{60}$ Sermons frequently elides conduct literature with feminist criticism. Katarzyna Bronk is a good example in the 2014's “Much, I am Sure, Depends on You" which summarizes the way that conduct literature reified the role of women in a patriarchal society, and attempted to reconcile eighteenth-century women to their subjugated position in society. Recent literary criticism of Pride and Prejudice has

\footnotetext{
${ }^{59}$ Some of these tensions go back to its oral history in fairy tales. Pride and Prejudice has parallels in "Beauty and the Beast," a story about a very unstable thing: transformation. Since our omniscient narrator occasionally aligns herself with a female voice, Marina Warner might argue that this story is told by a woman and therefore, "places the male lover, the Beast [Mr. Darcy], in the position of the mysterious, threatening, possibly fatal unknown, and Beauty, the heroine [Elizabeth], as the questor who discovers his true nature (Warner 275).

60 William St Clair addresses the remarkably long print run from reprints of Sarah Pennington, Doctor Gregory, Fordyce's Sermons, and Hester Chapone's Letters (275). These were texts written and published before the French Revolution that were later reissued to meet a new demand for older certainties (275). St Clair believes that the aspirational tone of several of these works, including the desire to see "how a society should operate in an ideal world" were part of the appeal of conduct literature in the Romantic Period (276).
} 
been incredibly diverse in terms of subject matter, speaking to the enduring power of Austen's writing. Moreover, this diversity also speaks to the versatility of the Pride and Prejudice narrative, wherein critics and readers can find exactly what they are looking for within the text, and if they can't, to almost revise the text in order to see what they want.

Feminist scholars have recently focused on character-doubling in Pride and Prejudice. Since I would like to argue that Austen echoes Fordyce's language in a way that doubles their ideas, the feminist reading has proven to me relevant to my own argument. Melina Moe's "Charlotte and Elizabeth: Multiple Modernities" argues that the straightforward romantic plot naturally puts Charlotte Lucas and Elizabeth Bennet's characterization at odds, when they are more similar than different. In "Pride and Potentiality" Megan Stoner Morgan argues in this article that by doubling Elizabeth Bennet with other characters within the novel, Elizabeth is set up as superior in the eyes of the reader (1). Morgan argues that the Fordycean double, Mr. Collins might be another potential double for Elizabeth Bennet because Austen is presenting Elizabeth's behavior in ways that suggest that she may be as," willfully self-deceived as her despised cousin" (6). I will argue that this form of doubling shows Mr. Collins as a character who is unable to change, but unlocks change in Elizabeth Bennet, as she learns to not always trust her first impressions.

Susan Allen Ford's 2013 "Mr. Collins Interrupted" shows Mr. Collins as "Fordyce writ large" (1). Ford argues that we can understand Austen's characters (and they also can understand themselves) by presenting them as readers. Laura Vorachek's "Intertextuality and Ideology" of 2005 suggests, through a discussion of characterization that Austen is 
cherry-picking the ideas from Fordyce that will enhance her satire, because he can be a tool of her imagination (Vorachek 129). Margaret Turnbull in "Jane Austen and James Fordyce" of 2007 call Austen's novels "the gentle correctors" of Fordyce's Sermons (Turnbull 50). My argument modifies this line of thinking, insofar as I believe Austen left the majority of Fordyce's ideas in her novel to provide the necessary conflict present in any romantic comedy, as well as to show how these elements are always contradictory to the romantic plot as much as they are in conflict with each other.

Austen relies on the religiosity of Fordyce's language to contrast with other character's behaviors, and hold up mirrors to their own anxieties, whether through the pain of embarrassment, or through humor. Fordyce is the necessary contradiction and conflict that will speed along the romantic plot of Elizabeth Bennet and Mr. Darcy, which works, because the elements of conduct literature-like our early images of Elizabeth and Mr. Darcy—are always in perpetual conflict. In short, Bronk might argue that conduct literature is keeping women submissive, Turnbull and Ford emphasize the satirical elements in Fordyce/Austen, but Moe, Morgan and Vorachek argue that Austen is still indebted to Fordyce. I argue that Austen utilizes Fordyce not to emphasize satire, but to emphasize that all of the elements of both conduct books and novels are always in contradiction to one another.

\section{Pride and Prejudice's Universal Truths:}

After reading Pamela and Evelina, it's finally in Pride and Prejudice where we see a story that at first glance is a perfected romantic plot, seemingly designed for massconsumption, and claiming to be devoid of the ambivalence and controversy that 
continuously needles readers of Richardson and Burney, who struggle with the aggressive accounts of assault and abuse in their gender dynamics, and the fact that the world is such a dangerous place for women in those narratives.

After the conflicting and even contradictory relationship dynamics in Austen's first published novel, Sense and Sensibility, Austen concludes with an almost jarring half-moral ${ }^{61}$ that reveals the need to justify the final marriage plot in a way that hearkens back to earlier novels of this genre. Like Pamela, Sense and Sensibility has the rakish Mr. Willoughby-who fails to keep Marianne's heart, instead following more mercenary inclinations. Instead, she is married off to the older, sadder Colonel Brandon. It's an inelegant ending. And the gracefulness of Pride and Prejudice is usually a starting point for many critics-as well it should be. From the first lines, "It is a truth universally acknowledged..." Austen is attempting to create, through satire or sarcasm, a universal truth, which is in this first line: the rules of courtship and marriage in our society are so arbitrary that they border on the ridiculous, yet we keep investing in them (Austen 1).

The all-importance of the marriage plot lies heavily on the characters in Pride and Prejudice, the same way that it is the primary concern of Fordyce. The word "wife," when used un-ironically, though with humor, is omitted when Elizabeth Bennet first sees the grounds at Mr. Darcy's house, Pemberley, but "at that moment she felt, that to be mistress of Pemberley might be something!" (emphasis mine) (Austen 185).62 To be a wife is to be the

\footnotetext{
61 See Elaine Bander's "From Cecilia to Pride and Prejudice: "What becomes of the moral?"” for an in-depth discussion of this "false moral" and one that also appears in Austen's Mansfield Park.

${ }^{62}$ Charles Perrault's Blue Beard fairy tale includes a party scene with Blue Beard's young wife deciding that, "the Master of the House [might] not have a Beard so very Blue, and that he was a might civil Gentleman" (1819). Both scenes, Austen and Perrault, are played for humor. Blue Beard's wife is probably intoxicated, and has really enjoyed the party, and Elizabeth Bennet is in awe at the gracious splendor of the Pemberley Estate.
} 
leader, the mistress of an establishment. Austen does not lose sight of that fact. Pamela must learn how to be the mistress of a village and provide charity to the poor. She must be taught how to behave by her husband. However, Austen's heroines in Pride and Prejudice (if not in Sense and Sensibility) seem more attuned to natural leadership of a grand estate, and village as a mistress of great property (and propriety: she must exhibit good conduct, she must "lead with" good behavior, going back to the Classical Latin definition).

The humor in Pride and Prejudice often stems from contrasting the behaviors of well-behaved people, and people who are disrespectful, inconsiderate, or vulgar. But when it comes to Austen's use of Fordyce's Sermons to highlight important character traits, there is just as much collusion between the Austen-heroine and the Fordyce-moralizer, as there is collision between their ideas of self-awareness (or lack thereof). Austen might be overtly using Fordyce's Sermons to dramatize how selfishly unaware most men are, in Pride and Prejudice, but that level of unaware selfishness is a fault of the heroine as well, and might even be a fault of the reader, since they are complicit in their first impressions and first judgments of these characters.

\section{Fordyce the Reluctant Satirist:}

In terms of readability, Fordyce is staid and boring. His religiosity is ridiculous, upon first analysis, but that doesn't mean that he intended them that way. James Fordyce, a Scottish minister in the mid-to-late eighteenth century, rose and fell from popularity rather quickly. He was a single man when his Sermons to Young Women were published in 1766,

Both of these humorous justifications show that Austen was not afraid to borrow the language and tone of fairy tales in the creation of her own romantic plot. 
before the American Revolution, and before Jane Austen was even born in 1775. He didn't even marry until around five years later in 1771. At the time of the writing of his Sermons, Fordyce had very little experience interacting with women, beyond that of his profession. His language is didactic, polemical, and essentially polarizing. While it cannot necessarily be argued that he is a raging misogynist, his language towards the intended audience of his Sermons, these "young women," shows a remarkable lack of knowledge about the female mind, and comes across, even at best, as insanely condescending. Prompted to publish from an "unfeigned regard for the Female Sex," Fordyce claims to regard women too highly to let them be charged with the decline of society that started with Eve (Fordyce iv). And Fordyce does not claim to use flowery language, or opaque meanings. In fact, he reflects on how he has "rendered the voice of Truth acceptable amongst those who are daily addressed in the language of Flattery" (Fordyce v). At least Fordyce knows how his tone might come across, and believes himself to be merely blunt, as opposed to condescending and hyperbolic. He is a rhetorician after all, a "Preacher" in his words (Fordyce v).

Fordyce's Sermons were meant to set young single middle-class-women on a righteous path (Fordyce v.1,12). Perhaps when read out loud, Fordyce might have seen his Sermons as a gentle, brotherly lecture of advice, as opposed to an obtuse collection of sexist assumptions so ripe for humorous parody. There is always secularity present in religious texts, and it is present in Fordyce, because he anticipates multiple readers at the same time: he seems to imagine a group of young women listening to his advice in order to become the best wives and mothers they can be. The behavior of women, and what makes them marriageable are not deep religious questions, but they are the concerns of an unmarried man living in the world. 
Critics $^{63}$ have noted how Austen uses Fordyce's language within her own narrative. Fordyce concludes his Introduction with the thought that, for a man, "women of worth and sense are to be found everywhere... amidst the coolnes [sic] of reflection" (Fordyce vi). Austen uses Fordyce's word-choice to describe an almost caricatured virtuous woman. Mr. Bennet claims with mock-gravity that his third daughter Mary, is a "young lady of deep reflection" (Austen 4). It is Mary who claims to hold the greatest moral authority of all the sisters-probably, as the narrator says, because she has the least beauty (Austen 17). Because the reader is caught in the fairy tale elements of the novel, they are meant to see archetypical characters as good, or bad and to see their behaviors rewarded as such. Mary's position in her own family as an archetypical conduct-book-girl is not punished in Austen's novel, but it's not exactly rewarded either.

\section{The Irony of Mary:}

Out of all the Bennet sisters, Mary is perhaps closest to what a good Fordycean woman might look like, but she is not a perfected ideal, because she lacks the selfawareness to cater to the opinions and judgments of men. Instead, she is pedantic and devoid of humor. In some ways, the conduct book created her character, because on the surface-level she is everything that Fordyce would endorse However, Mary’s “happy ending" at the conclusion of Pride and Prejudice is merely the fact that her sisters have left

\footnotetext{
63 Michael McKeon discusses how the different dynamics between what was considered public and what was considered private knowledge affected writerly style, including Austen's weaving in and out of different points of view in free indirect discourse. See The Secret History of Domesticity of 2005.
} 
home. Even her unmarried younger sister Catherine, or "Kitty," lives primarily with her respectably married sisters, Jane and Elizabeth. But Mary remains:

and she was necessarily drawn from the pursuit of accomplishments by Mrs. Bennet's being quite unable to sit alone. Mary was obliged to mix more with the world, but she could still moralize over every morning visit; and as she was no longer mortified by comparisons between her sister's beauty and her own, it was suspected by her father that she submitted to the change without much reluctance (Austen 295-296).

As happy romantic endings go, this leaves much to be desired. The mother, Mrs. Bennet's children are, at various times, victims of her neuroses, and her shallow cruelty. Mary might deserve better than the fate that is prescribed to her. Certainly, she is someone musically lacking in "genius or taste" who embarrasses her family at parties, but she is also the child of a negligent emotionally unavailable father, and an irresponsible gossip of a mother, neither of whom validates her experiences as a woman, or a daughter (Austen 17). ${ }^{64}$ If Mary turned out well, it was in spite of her parents. Perhaps it was the negligence of her parents that formed what was right all along or allowed it to grow and mature with upright principles. As her father mentioned earlier Mary is a great reader, and perhaps the reading allowed her correct taste in books to guide her towards the right behaviors. But Mary is not rewarded with marriage, only an increased sociability within her family unit. Austen cannot validate the Fordycean woman with an appropriately romantic reward but is quasirewarded in the fact that she is no longer isolated or made to feel inferior.

\footnotetext{
64 After reading through Mary's conclusion of Pride and Prejudice, readers might begin to wonder, as Fanny Price does for her sister, Susan - to paraphrase Mansfield Park - not that she should have been provoked into resentment by her family's abuse of her, but that so many good behaviors and morals should have been hers at all.
} 
Mary is a pawn to the overarching moral of Pride and Prejudice: vanity is the worst vice that a person can have, because it will lead to, (or conduct to) just about any other vice, including pride and prejudice both. However, while Fordyce condemns women who show themselves in the "markets of Vanity" he also encourages women to become vain and narcissistic when he urges them to police their own behaviors around men in order to get to their "principal aim" of attracting a good husband $(118,167)$. While painting Mary's fate as a reward for her many solitary hours in study and practicing music, the reader is being urged to forget that Mary has already been punished through her lack of beauty for her excessive vanity. Her fate is a softened chastisement of her former bad behavior, since she is not rewarded with a marriage. For both Austen and Fordyce, a good marriage is the ultimate reward.

Mary becomes the Fordycean mouthpiece as the crises in the Bennet family amplify, but as a moral mouthpiece, her opinion is not validated. When their youngest sister Lydia runs away with Mr. Wickham, Mary whispers some moralizing to Elizabeth as they sit down to eat:

Unhappy as the event must be for Lydia, we may draw from it this useful lesson; that loss of virtue in a female is irretrievable-that one false step involve her in endless ruin - that her reputation is no less brittle than it is beautiful, - and that she cannot be too much guarded in her behaviour towards the undeserving of the other sex (Austen 219).

Of course, Elizabeth lifts her eyes from the table and just looks at her sister in amazement at this sort of language against her own sister, but it's a direct extract from the language of 
Fordyce that Mary is made to read (and re-read in almost all the cinematic adaptations of the book):

Remember how tender a thing a woman's reputation is; how hard to preserve, and when lost how impossible to recover; how frail many, and how dangerous most, of the gifts you have received; what misery and what shame have been often occasioned by abusing them! I tremble for your situation. Suffer me again to put you upon your guard (Fordyce v. 1, 44).

This emphasis on tenderness, frailty, and fragility, even the brittleness of respectability, coupled with the advice to remain on guard against the threats to respectability that will constantly assail women, are almost identical. Yes, Elizabeth is shocked, even appalled by Mary's language, even though it is pretty much a parroting of the conduct book that her cousin, Mr. Collins, attempted to read to the family back in November. Austen intends for Mary to be the voice of the conduct book girl: horrified at the vice that has manifested in other young women and advising extreme caution in any form of sociability (which contributes to the irony that sociability is Mary's reward at the end of the novel).

\section{Elizabeth in Judgment:}

Elizabeth is quiet in her initial judgements of Mr. Collins. It is actually her father that derives the pleasure of glancing in his favorite daughter's direction (Austen 51). Baby sister Lydia is not as subtle in her judgements, when she "gape[s]" as Mr. Collins opened Fordyce's Sermons, and "before he had, with very monotonous solemnity, read three pages" interrupts him to gossip to her mother about life in Meryton (Austen 52). Jane and Elizabeth beseech Lydia to be quiet, but it's too late, and Mr. Collins, being extremely offended, forgoes the reading, and plays backgammon with Mr. Bennet. But readers 
immediately align themselves with Elizabeth in that scene, when, though they are silent during Mr. Collins' reading, they are absolutely relieved that it is over. Elizabeth rejects the Fordycean characters but falls prey to her own good opinion of herself. When she reads Mr. Darcy's letter, which discloses his own history with Mr. Wickham, she exclaims that her "vanity, not love" was her folly (Austen 159). It is her vanity that must be punished, and her newly acquired humility rewarded with her marriage to Mr. Darcy.

After Elizabeth and Jane return to their home after Jane's illness, the two sisters find everyone in their family employed in their usual pursuits, including their sister Mary, who was "as usual, deep in the study of thorough-bass [sic] and human nature; and had some extracts to admire, and some new observations of threadbare morality to listen to" (Austen 45). The free indirect discourse implies that Fordycean morality is another form of feminine accomplishment, like music. But Austen uses this humor to align the reader with the judgments of Elizabeth. The secularizing capability of the novel is apparent here, inasmuch as the heroine Elizabeth's opinion of the world is being formed by a plurality of voices and opinions. But some of the voices are right, and some of them are wrong. By commandeering the language of a conduct book author, Austen makes the reader's knowledge and understanding grow alongside Elizabeth's, for as the reader allies with her way of thinking, they also absorb her flawed moral judgments of her sisters and of any potential love interest, which must be corrected, and transformed into right thinking and right conduct. Austen absorbs elements of Fordyce to create her novel, but both the conduct book and the novel have contradictory characterizations and value-judgments that the novel can use to further the progression of character-development, that "novelize" the conduct book. 
Elizabeth's character is diametrically opposed to any sort of threadbare morality. Most closely resembling her intelligent, sarcastic father, Elizabeth appears on the stage of the novel as a delightfully witty, charming young woman. Mr. Collins, upon his own disastrous proposal of marriage to Elizabeth, notes that Elizabeth will find the manners of his ogre-like patroness, Lady Catherine de Bourgh, "beyond anything I can describe; and your wit and vivacity, I think, must be acceptable to her, especially when tempered with the silence and respect which her rank will inevitably excite" (Austen 81). With that "tempering," Mr. Collins most likely is repressing his fear that the wit and vivacity of his potential young bride is something that will bother him, his Patroness, and probably Fordyce. Susan Allen Ford talks about Mr. Collins as the Fordyce-mouthpiece of the novel (Ford 1). However, it might be easier for the reader to miss how Mr. Collins and Elizabeth share several similarities. They both form judgments based on appearances. Mr. Collins moves down the birth order of Bennet daughters to propose to, from Jane to Elizabeth, next in both "birth and beauty" (Austen 53). Elizabeth looks at Mr. Wickham's handsome appearance, which at once tells her that his intentions are sincere and is aligned with the narrator's voice when looking at the "tall, heavy looking" person of Mr. Collins with his ridiculously formal airs (Austen 49). When Mr. Wickham complains about his ill-treatment by the Darcy family, Elizabeth thinks him "handsomer than ever" as he expresses his feelings, and as Mr. Collins attempts to propose to her, she attempts to do needlepoint in 
order to distract herself from alternating feelings of both "distress and diversion" (60, 81). 65

If Mr. Collins is Fordyce, then Elizabeth by default exhibits a few characteristics of Fordyce as well. Fordyce's constant concern with how women "appear" in public shows that he forms judgements based on appearances (44). With that, the satire of Pride and Prejudice becomes a sharp double-edge. Though Elizabeth's motivations are not sacred, but instead prompted by superficial impressions and vanity, Austen has used religiously inspired language to move her through her marriage plot. The famous proposal scene of Mr. Collins and Elizabeth is articulated in almost all adaptations of Austen's work, but the scene of Mr. Darcy's proposal, and Elizabeth's acceptance is usually only implied, the same way that it is on the page (Austen 280). Austen's reticence is similar to a conduct book, which usually redirects the conversation of marital intimacy towards how women can be good wives and mothers. Fordyce also shows how the display good femininity both inside and outside of marriage relies heavily on public behaviors and the mere implication of internally good morality.

\section{The Vain Co-Opting of Good Conduct:}

Fordyce claims to his young female audience that, "the les[sic] vanity you betray, the more merit we [men] will shall always be disposed to allow you [young women]" (Fordyce v.1, 77). Of course, Fordyce is being cynical, here. It's not that women will never feel vanity, in fact the implication is that they will always have it in excess, but that they must not

\footnotetext{
65 Megan Stoner Morgan talks about Mr. Collins as Elizabeth's double, though Elizabeth has the privilege of being the main character, while Mr. Collins is a more static article of comedic relief (Morgan 6).
} 
reveal it to their potential life-partners. External and superficial first impressions are initially what doom Elizabeth Bennet and Mr. Darcy, but their essentials, the true compatibility of their intelligent characters is what ends up saving their relationship and allows it to progress. The only thing that can be regulated in a person is what is visually, and therefore socially perceived by others. Maybe it's because men are more visual than women? Or perhaps it's because the courtship rituals of the eighteenth century only allowed for people to get to know each other on a superficial level, if that's all they cared about. Vanity plays a huge part in human attraction for eighteenth-century courtship rituals; it's unavoidable. Fordyce refers to the "markets of Vanity" when he is bemoaning the lack of female reserve and modesty in public (similar to how critics have referred to the "marriage market" of the eighteenth century as it was satirized in William Hogarth's artwork, such as "Marriage a la mode") (Fordyce v. 1, 118). Women insist on dressing provocatively, and broadcasting their availability to men, and Fordyce is horrified, but this was a common social performance. Vanity was a commodity sold on the market of human characters, and people (especially women) were treated as goods to be bought or sold for similar reasons. While Fordyce preaches against vanity, it is in Austen's novel that vanity is punished. Mary Bennet's vanity is punished when she is denied the marriage plot and consigned to a life socializing with her parents. Elizabeth's is punished by embarrassment, and awkward feelings towards someone who she has a growing attraction to, and Lydia's vanity is punished by her marriage to the rake, Mr. Wickham, after her immodest and indiscrete behavior in public. If there is a "moral" to the fairy tale that is Pride and Prejudice, it is that selfish vanity can be a destructive force that will inevitably be punished. 
Rather than punishment, Fordyce would prefer to use positive reinforcement for good female behavior, at least on the surface-level. He stresses the notion that "Modest Apparel" is a "positive attractive to honorable love" (Fordyce v.1, 53). When a woman seeks to attract attention by showing a "sweet solicitude to please by every decent, gentle, unaffected attraction," in turn, the men are "soothed... subdued... willing captives (Fordyce 53). After all, the sexes were "made for each other" (Fordyce v. 1, 53). Even the:

"loosest man, shall in a sober mood be pleased, be touched with the bashful air, and reserved dres [sic] of an amiable young woman infinitely more than they ever were with all the open blaze of laboured beauty, and arrogant claims of undisguised allurements; the human heart, in its better sensations being still attempered to the love of virtue" (Fordyce v. 1, 54).

Fordyce wants to make women aware that behaving in a coquettish manner will not help them and will in fact attract the wrong type of attention, which might lead to a bad marital partnership (or worse, a sexual fall and a destruction of a respectable reputation). He believes that good men will still be attracted to the essential good of female beauty that is always both partially obscured, and yet signified by modest apparel. Yet he doesn't discuss the internal moral compass that should be directing the young woman towards rightbehavior.

Fordyce claims that men are better "judges of the deportment of women" than women themselves (Fordyce v. 1,106). What he is implying is that men are capable of observation beyond women's constant self-referential, gossiping natures. He considers himself to be very generous regarding how much women talk about their clothing, "fashions, and fashionable amusements" because it is just a natural limitation of the sex 
(Fordyce v.1, 198). He would love to see the female sex more "accomplished" but certainly does not want a collection of "Learned Ladies" as potential life-partners (Fordyce v.1, 202). Since he does a rather literal reading of Saint Paul, and the poet John Milton, Fordyce can perhaps be forgiven for the some of the more virulent chauvinism. However, he cannot deny that women are reading some texts, including Pamela, by Samuel Richardson. If women weren't reading, then how could they even ask, with any earnestness, whether a "reformed rake" would really make the "best husband," or even an acceptable one (Fordyce v. 1,134). (Of course, that is the crux of Pamela, where the answer is a resounding, "yes" as discussed in the first chapter of this dissertation.) Fordyce goes as far as to recommend not Pamela, but Clarissa, by Richardson, later in his conduct manual, as a novel that portrays the apex of female "excellence" in the protagonist, before of course Clarissa's rape and eventual death at the hands of the brutal abductor and rake, Lovelace (Fordyce v. 1, 147).

Other than that very bleak tale, there are almost no novels that Fordyce recommends to his young, female readers (Fordyce v. 1,148). He heartily endorses reading religious works and having men in authority read such texts to women if they do not understand them, but novels might be too stimulating to the sensibilities of young female readers, with very bad examples of both masculine and feminine traits, and characters riddled with vices. Reading novels will not help promote female modesty, discretion, or discipline. Instead, they will provoke sensual feelings in young women, and perhaps leave them with unrealistic expectations about the physical rePSYClationships between men and women. 
Jane Austen consistently ends her romance plots at the altar, and merely nods to the eventual happiness of the couple. There are never any sensual "bedroom" scenes for her couples who are rewarded with marriage. ${ }^{66}$ Austen never married, and it would have been far beyond the rules of propriety for her to postulate how the marriages will go. Married life as depicted in in many of Austen's novels is generally not a very happy affair, and Pride and Prejudice is no exception. Mr. and Mrs. Bennet prove to be a poorly matched couple. Elizabeth Bennet is all too aware of the consequences of such courtship rituals, because these are the practices that brought her parents together, and her mother and father are passing on their bad traits to their offspring. Elizabeth notes how her father, "captivated by youth and beauty" in his first impressions of the woman who would become his wife,

"and that appearance of good humour which youth and beauty generally give, had married a woman whose weak understanding and illiberal mind had very early in their marriage put an end to real affection for her" (Austen 180).

Here, Fordyce's attitudes about how men and women relate to each other, solely on a superficial level are being commandeered by Austen. She has even borrowed his language, when he talks about how men are traditionally "dazzled by youth, vivacity, and beauty" before they can look at a woman with a "cooler" eye, or sensibility (Fordyce v. 1,106). ${ }^{67}$ Both Fordyce and Austen are cautioning against acting on their first impressions, especially

\footnotetext{
${ }^{66}$ See Jillian Heydt-Stevenson's Austen's Unbecoming Conjunctions: Subversive Laughter, Embodied History for a discussion on how the bawd (i.e. Mrs. Bennet) in Austen gets displaced onto other things. Heydt-Stevenson argues that other material objects, and other appetites become placeholders for sexuality and desire, complexifying the eighteenth-century ideal of the demure, compliant female devoid of sexual impulses. ${ }^{67}$ It is important to remember that the first working title of Jane Austen's Pride and Prejudice was "First Impressions," which is a preoccupation for both Fordyce and Austen, considering how courtship practices were enacted that the time of the writing of both texts.
} 
when choosing a spouse. The difference being that Austen's characters are allowed to grow past these first impressions and develop inner lives.

\section{Fordyce and Austen, Not in Conflict but Combination:}

While mocking Fordyce on the pages of the novel, Pride and Prejudice's Elizabeth Bennet $=$ forces the reader to reevaluate, along with Elizabeth all the superficial judgements that she makes about the world around her, in order for the narrative to reach its happy conclusion. A fundamental part of Fordyce's modesty discussion hinges on how women can avoid the sin of vanity. That is also a main preoccupation of Austen, especially for the novel's occasionally overly exaggerated moral mouthpiece: Mary Bennet in the earliest chapters of the novel. We as readers are first inclined to reject Mary for her vanity, but then realize at the conclusion of the novel when her reward is socialization, that we should have not rejected her, because she was simply the product of her environment.

After the first assembly room ball, after being snubbed by Mr. Darcy, Elizabeth is dwelling on her (slightly) injured pride, or vanity. Mary differentiates between the two:

"Vanity and pride are different things, though the words are often used synonymously. A person may be proud without being vain. Pride relates more to our opinion of ourselves, vanity to what we would have others think of us" (Austen 14).

Though Mary makes this differentiation, Elizabeth, when aligned with the narrator, show that vanity is also Mary's own sin, giving her the desire to apply herself to her musical and moral studies, but still making her a pedant (Austen 17). Mary's flaws, like her sister Elizabeth's include a certain lack of introspection, or the ability to reflect. But in contrast to Mary, Elizabeth is not a flat, or static character, and it will be important for her to 
differentiate between what is true vanity, and what is just confidence, before she can get the conclusion of her marriage plot. She is being slightly self-deprecating when she refers to her own vanity as not taking, "a musical turn" when she is talking to her best friend Charlotte Lucas, and Mr. Darcy (Austen 17). Her lack of musical vanity means that she did not turn in to her sister Mary, but she is also acknowledging that she has vanity, and that implies that at least she is partially self-aware. Since vanity is the moral sin that the Austen fairy tale will condemn, it is common for Austen to remind her reader of the problems with vanity throughout the novel.

Elizabeth's preoccupations with vanity linger into her next interactions with Mr. Darcy, when she visits Netherfield to care for her sick sister. Mr. Darcy is undergoing a sort of gentle ribbing by his friends, and the witty barbs of Elizabeth's humor. When finally nettled, he claims:

\footnotetext{
"it has been the study of my life to avoid those weaknesses which often expose a strong understanding to ridicule."

"Such as vanity and pride,"[Elizabeth said]

"Yes, vanity is a weakness indeed. But pride-where there is a real superiority of mind, pride will be always under good regulation."

Elizabeth turned away to hide a smile" (Austen 43).
}

By turning away, Elizabeth is preventing her own face from revealing her judgments about Mr. Darcy, and her desire to laugh at how well he is meeting all her impressions of him. Vanity and pride will continue to get in the way of Elizabeth and Mr. Darcy's romance as their story progresses. Obviously neither Austen nor Fordyce sees vanity or pride as virtues. Austen can use Fordyce's language, to describe the sin of pride, and to mock vanity 
through Elizabeth Bennet, but she can only attack what is external and visible, she cannot attack a person's character. As her characters move towards greater self-knowledge, the reader must continue to take them at their word, that they are learning more about human behavior off-stage, so that when they acknowledge that they have been, "very weak and vain and nonsensical" as Elizabeth acknowledges to Jane, but then believes that she can be better, the reader can also believe her (Austen 172). Though the reader has no evidence that any of Elizabeth's own vanity and pride are going away, her proclamation that she is learning more about herself after she rejects Mr. Darcy's first proposal is taken at face value.68 Perhaps she is doing the intellectual and emotional labor behind the scenes.

One can only wonder what Fordyce would have thought of Pride and Prejudice, published around forty-seven years later, and his embarrassingly awkward appearance in the Bennet family early in the book, from Mr. Collins. He might have been decrying the inequality of a marriage between Mr. Collins, and Elizabeth Bennet. Mr. Bennet also worries about the most beloved daughter, Elizabeth, in language similar to Fordyce's, when Elizabeth announces her plan to marry Mr. Darcy (shortly after Mr. Darcy has asked his permission of Mr. Bennet). Her father warns her:

"I know your disposition, Lizzy. I know that you could be neither happy nor respectable, unless you truly esteemed your husband; unless you looked up to him as a superior. Your lively talents would place you in the greatest danger in an unequal marriage. You could scarcely escape discredit and misery. My child, let me not have

\footnotetext{
68 When Bernie Su created The Lizzie Bennet Diaries, he gave the line to Ashley Clements, the "Lizzie Bennet" character, who claims in disgust, "Vanity and pride, the Darcy family crest. It's probably in bronze over his bed" so that Lizzie can be revealed to have felt hurt by Darcy's initial spurning of her at a dance and confused by her own ambivalent sexual feelings towards him (Su 2013). (After all, she is thinking about his bed.)
} 
the grief of seeing you unable to respect your partner in life. You know not what you are about (Austen 288-289).

Fordyce refers to his tremendous fear for the women that are, "unequally yoked" in marriage using very similar language, even referring to "misery" and the contempt of the world (Fordyce v. 1,32). He relies on feminine propriety as a preservative against sexual sin, but he also sees the importance of men behaving correctly towards virtuous women. The implication here is that the relationships between the genders will always be unequal and unhappy if both men and women do not behave correctly. In this critical scene, where the marital fate of Elizabeth Bennet lies in her father's hands (which obviously Fordyce would approve of) we see Mr. Bennet's fears, and Fordyce's united in language, as Austen has been doing for most of the novel, but this time, not ironically, or even meant for satire. It's not that marriages based on intellectual equality and mutual respect are bad, it's more that those qualities are impossible for the authors of novels and conduct books to identify or measure. The impulse for Austen's discourse is to make the situation ironic, humorous or satirical.

This interaction with Elizabeth is the first time that Mr. Bennet has not been joking or flippant to one of his daughters. His rage at Lydia was silent, and he removed himself to London for most of it, and to Jane he merely mocked her for being so similar to her fiancé (Austen 266). It is with Elizabeth that he reveals the anxious concern of a parent (which Sarah Pennington or Doctor Gregory would probably understand perfectly, as we will see in the next chapter of this dissertation). Here is where Austen successfully creates a secular new genre: the conduct-book-romance. The earnest anxiety of Mr. Bennet contrasts with his earlier sarcasm and flippant attitudes towards his family, and this contrast grants him 
authority in this interaction with his beloved daughter. In turn, her tears depict an authentic emotional reaction to her father's anxiety. Both characters display the roles of loving parent and child perfectly on the page. The reader is satisfied that Elizabeth has reformed, and is deserving of her successful marriage plot, though Mr. Bennet has taken on the voice of Fordyce (i.e. condescending to tell his daughter that she doesn't know herself as well as he knows her).

\section{Conclusion:}

When Elizabeth Bennet rejects Mr. Collins's offer of marriage, she defends herself, and her desires, by wishing him two things: to be "very happy and very rich," and gently offers her hope that by refusing him, she can guarantee him these things (Austen 82). But in the world of eighteenth-century courtship, to be happy and to be rich were really the only two considerations that anyone could possibly have, at least on the superficial level that Elizabeth is capable of at this moment in her story. When defending her decision to marry Mr. Darcy to her father, she is overcome with emotion describing Mr. Darcy's merits, and her growing affection for him (Austen 288). And Elizabeth doesn't do a particularly decent job of articulating to her father what she admires in Mr. Darcy. She dwells on his lack of "improper pride" and how perfectly "amiable" he is, but she seems shy, or embarrassed to admit how deeply she does feel (Austen 288). Other than its essential "rightness" for the perfect romantic plot, even Austen cannot really imagine what Darcy and Elizabeth's marriage is based on. Fordyce was unmarried at the time of his writing, as well, and in his representation of women's characters, clearly, he had no idea of what marriage looks like. Both Austen and Fordyce would like for marriages to be happy. It's just that there is no way 
to depict exactly how to do that on the page. Austen normalizes Fordyce's ethos by bringing elements of romance to instruct the hero and heroine and guide them towards improving their character. Austen is successful, because romantic love is also impossible to identify or measure on the page, but it is readable and relatable.

Perhaps what is most common about both the conduct book author and the novelist is that they both have to universalize what might be a specific situation to legitimize their genre. It is not always a truth universally acknowledged that a single man in possession of a large fortune must be in want of a wife, but in Austen's world, through humor and sarcasm it becomes a universal. In Fordyce's world, a woman's sexual reputation is her most valuable and most fragile possession, and through the voice of Mary Bennet in Pride and Prejudice, a woman's reputation becomes evidence of a character's own lack of introspection and her vanity.

Part of the reason for this convergence of language, is the focus in Pride and Prejudice on the external versus what is internal. As Margaret Turnbull argues, Fordyce "preaches self-righteousness, superficiality, and that a young woman's responsibility is to male opinion" (50). If good conduct is only created to appease the superficial, subjective nature of the male gaze, as Fordyce indirectly claims, then what does it mean to have truly "good" character? Elizabeth Bennet learns how to reserve her first judgments about people through the plot of Pride and Prejudice, but that doesn't necessarily mean that she is a better person by the end of it (unless acquiring true love has made her better). Mr. Darcy claims that his "dearest loveliest Elizabeth" has made him see his own flaws and taught him humility, but the novel ends before the reader sees evidence of this transformation (Austen 
282). In the last chapter of this dissertation, Mary Wollstonecraft will be confronted with this same issue. The essential and the performative act of goodness become the two elements of conduct literature that are most in conflict with one another, and therefore are the two elements that drive narrativity forward in both the novel and in Wollstonecraft's case, the manifesto. 
Chapter 4: Conducted to Absence: Mary Wollstonecraft's A Vindication of the Rights of Woman and Doctor John Gregory's A Father's Legacy to His Daughters

\section{Introduction:}

The works I will be discussing in this chapter were instigated by a crisis. A death in the family, the looming threat of a war-both are crises to these two authors, and crises played out as an intrinsic problem in education. I will argue that even educational treatises of the eighteenth century acted as conduct literature could: by advocating for a set of good educated behaviors, and not for an actually virtuous moral code.

This chapter will highlight the differences between good conduct and virtue, and will expose the untenability of the conduct ethos, through the work of John Gregory and Mary Wollstonecraft. For both authors, virtue appears as something ephemeral, but conduct and education appear as concrete objectives that could last beyond the reading of the advice texts and help the young woman to learn and grow more. Gregory's teachings, for example, privilege good behavior, as he encourages young women to display a set of superficial accomplishments on the marriage market. It matters that his daughters have good morals and values, but it also matters how potential husbands see them behaving. For Gregory, women should pretend to be ignorant so as not to intimidate men. Wollstonecraft takes on Gregory for appearing to endorse duplicity and hypocrisy in his female readers as they seek to attract husbands. Wollstonecraft, however, is ambivalent as to what constitutes goodness as opposed to conduct. Her concern about education merely substitutes one type of conduct for another.

Because Wollstonecraft believes virtue can be cultivated, she is telling her readers not to behave as if they are innocent and foolish, but nevertheless to behave a certain way 
as well. Women must be as enlightened as their age and time in history demands of them, which is simply another form of behavior assimilation.

The greatest tension in these final texts becomes an issue of esse quam videri: the tension between being versus seeming to be, essence versus construct. Where does the "seeming" end, and the "being" begin? From Wollstonecraft's dialogue with Gregory, as she creates a conduct book of her own in $A$ Vindication, it's clear that goodness is not a substance: it's an act. Even in the act of reading the texts, we perform the superficial: we can't get past the "seeming," because virtue for Wollstonecraft may be performative: defined in terms of actions rather than values. Reading Wollstonecraft with Gregory exposes tensions within Gregory that would not otherwise be evident and reading Gregory with Wollstonecraft does the same thing: revealing tensions in Wollstonecraft that might otherwise go unnoticed. Gregory's tone of resignation is part of what authorizes his advice, but in contrast to Wollstonecraft, it also shows that his project is set up to fail. Since the genre of conduct advice teaches the reader merely to appear virtuous, rather than to be it, the conduct text is intrinsically hypocritical. And despite Wollstonecraft's claim that she was writing the antithesis of a conduct book, the Vindication reads like a conduct book itself, and lends itself to the same hypocrisy that any conduct book has. It's as much a fiction, and a fabrication, as any novel ever written.

\section{Literary Review:}

Much of the current scholarship surrounding Mary Wollstonecraft focuses on her rhetorical strategies in persuading her readers to champion women as rational creatures. This is the "universal" truth that she and Gregory claim that they are contending with, that 
woman are rational and should be treated like functional human beings. Andrew Dicus' article, "The Rude Mass and the Mighty Whole" discusses Wollstonecraft's polemical assumptions about "empirical objectivity" which is in direct contradiction to the reader's experience of the almost excessive pathos in her rhetoric, and her numerous emotionally wrenching anecdotes (337). Discussing the conflicting directions in Wollstonecraft, towards a social scientist's detached observations yet also towards appeals to logical and reasonable investment that are at play, provide more evidence for my own argument that Wollstonecraft's advice is contradictory, even when she tries to advise people on truly righteous conduct.

The primary area of focus in Wollstonecraft scholarship are studies of sentimentalism, sympathy, and sensation, the things that Wollstonecraft argues against so dramatically in her Vindication. Mary Beth Tegan uses "Mocking the Mothers of the Novel:" to discuss Wollstonecraft's ambivalence towards common eighteenth-century imagery and metaphors that might allude to sentimental or sensationalist fiction, because sensibility and immaturity can grow from reading sentimental novels (Tegan 359). ${ }^{69}$ Catriona Mackenzie describes how it is the standard in feminist commentaries to argue that Wollstonecraft's brand of feminism is "vitiated by her commitment to a liberal philosophical framework, relying on a valuation of reason over passion and on the notion of a sex-neutral self" (Mackenzie 35). While trying to avoid recreating sympathy in the minds of her readers, Wollstonecraft must rely on Enlightenment appeals to reason and

\footnotetext{
69 See also: Shaun Maurer, “The Female (As Reader: Sex, Sensibility, and the Maternal in Wollstonecraft's Fictions," of 1992 and Lawrence Kennard's "Reveries of Reality: Mary Wollstonecraft's Poetics of Sensibility" of 2001.
} 
necessity, which does not offer solutions to the problem of women's repressed status in society or define what it is to be truly virtuous. These omissions noted by Mackenzie help to facilitate my own argument that neither conduct books nor novels can create virtue.

\section{The Motives of a Vindication:}

Though many authors wrote in support of Edmund Burke's Reflections on the Revolution in France (1790) Wollstonecraft's Vindication of the Rights of Men (1790) opened the door to the public intellectual understanding of Mary Wollstonecraft as a polemicist and paved the way for what is considered her seminal work, $A$ Vindication of the Rights of Woman (1792), which argues for the place of women in society, and that their education and treatment by the patriarchy deserves radical revision. The first Vindication shows Wollstonecraft's desire to focus on upright social morality in the Enlightened Republic. She comes back to these ideas in more detail in the second Vindication. By focusing more on the social (i.e. educational) problems that young girls and women have in England at the end of the eighteenth century (as opposed to problems of economics or issues of modern warfare that occupied the world stage) the second Vindication takes on a more domestic tone, focusing on women's concerns, and daily life in the republic, therefore becoming, according to Janet Todd, more of "courtesy book than a political tract, concerning manners more than civil rights" (Todd "Introduction" xix). The title: $A$ Vindication of the Rights of Woman is not really in line with the contents of the text.

More than any one conduct book that I have discussed in this dissertation, Wollstonecraft blends the ideas of the personal and the political. Wollstonecraft takes her 
place as one of the first feminists in history, because she recognizes that furthering the rights of both genders leads to the progress and advancement of society. If women are kept back by the rigid rules of patriarchy, then all of society would suffer. The rights of men (in abstraction) are the same as the rights of women (in abstraction), for the soul of both genders was unsexed in the eyes of God. However, the soul must occupy a sexed body that social and religious or cultural codes can be imposed upon. If the mores of primogeniture, heredity and privilege were being dissolved for men across all of Europe, then these same gendered oppressions should no longer be enacted on women. These ideas, to treat women as rational creatures, i.e., as human beings, and not as property, was a seismic enough ideology that the famous Gothic novelist Horace Walpole gave Mary Wollstonecraft the title of a "hyena in petticoats," while for other first feminists, it made Wollstonecraft one of their first, and most divisive champions (qtd. Todd "Introduction" xix). But perhaps it is the action, the "treatment" which causes the problem, as opposed to the belief in equality.

Wollstonecraft wrote her women's Vindication very quickly. As a result, she rambles, digresses, and is incredibly inconsistent with her ideas, especially as she treats women's power. Wollstonecraft was part of the burgeoning sect of diverse writers who wrote in opposition to Burke, and the cult of sensibility, including the enervating, feminizing power of sentimental novels, like the novels that I have discussed in previous chapters of this dissertation. ${ }^{70}$ Wollstonecraft's text works like Chapone and Fordyce who advise their readers to engage with more realistic, useful texts such as history and bible stories. However, since she wrote rapidly, her ideas aren't always fully formed, and she

\footnotetext{
70 Which is why sentimentality and studies of sympathy are some of the most popular studies and discussions of Wollstonecraft's work.
} 
doesn't always define the important terms that she needs, such as good behavior. As

Andrew Dicus claims, sometimes virtue is only knowable through behavior.

\section{Education and Vindication:}

Wollstonecraft's topic is the problems in the education of young women. As a young woman Wollstonecraft was a voracious reader of anything and everything that came her way. Her education was hands-on (insofar as she was motivated to learn beyond her brothers and sisters). But she saw early that the void that was a woman's education, and the machinations of the patriarchy itself, that the establishment was against her acquiring knowledge of any kind-even against her understanding herself as woman.

As a result, Wollstonecraft argued for an active plan of education that satisfied both the developing mind and the growing healthy body. Men and women "must be educated, in a great degree, by the opinions and manners of the society they live in" (86). A mixture of Rousseau ${ }^{71}$ and Locke emphasized learning practical skills (not memorizing arcane pieces of Latin and Ancient Greek) and allowing children to play and practice what they might anticipate a trade or vocation to be. Alan Richardson writes in Literature, Education, and Romanticism how social relationships were created through the act of reading in the eighteenth century, and that changes in education and literacy education during this time shape how we read today. For Wollstonecraft, class or aristocratic position never factored into her version of salvation; it was more about the creation of good citizens to serve this God of Reason. The common behavior of overindulging the feelings, whims and fancies of

\footnotetext{
${ }^{71}$ In 1794, Wollstonecraft wrote in a letter that she had "always been half in love with [Rousseau]" and clearly her fraught relationship to his text Emile stems as much from admiration as from frustration (Todd "Introduction" xviii).
} 
girls in their developmental stages results in the transfer of this overindulgence to the children of their marital unions, corrupting the next generation.

Wollstonecraft claims in her introduction that her focus is on the innate virtue of all human beings. She uses virtue in its original sense, from the Latin "virtus" meaning strength or power (OED). She claims in her introduction that women who only are seeking love and emotional validation, that they should actually be exacting "respect" through their abilities and virtues (71). Her Enlightenment values hinged on the fact that all relationships should be formed by this mutual appreciation of similar value systems. However, she struggles to truly articulate what that means.

The best marriages (in Wollstonecraft's then unmarried eyes) were the ones not founded on mutual attraction, or in any form of infatuation, but instead, those that were formed by two people who might not actually care that much for each other but were more than willing to grow to be great friends. Friendship for Wollstonecraft is "a serious affection; the most sublime of all affections, because it is founded on principle, and cemented by time" (145). This was the type of lesson that young women should be taught, early and often. Obviously, there is advantage in her proposed supportive friendships over physical promiscuity in an era with barely rudimentary birth control (Todd "Introduction" xxiii). But Wollstonecraft doesn't know exactly what to do with emotional promiscuity either, and the allocation of one's affections. Wollstonecraft's ideal woman isn't exactly proficient at expressing real feeling. She is capable of intellectually diagnosing her feelings, but not necessarily in feeling them. Doctor Gregory's Legacy was frequently caught in the crosshairs of Wollstonecraft's attacks against sentiment and romantic love. But both 
writers display the same contradictions in their valuation of good behavior over good character, and both authors' projects fail, though for different reasons. Gregory's fails because he cannot live forever to consistently counsel his daughters on what is right and wrong. Wollstonecraft's fails because she cannot offer concrete solutions to the problems that she articulates. She can only urge better behavioral habits.

\section{The Moody Father's Fraught Legacy:}

A Doctor who built his career on healthy bodies and behaviors, John Gregory was born in Aberdeen, Scotland on June 3, 1724 to a celebrated family of physicists, mathematicians, and doctors who cultivated personal relationships with the likes of Sir. Isaac Newton. Gregory's own grandfather was the inventor of the "Gregorian Telescope." Doctor Gregory himself would go on to become a celebrated doctor in Scotland (James Gregory "An Account" 24). After the death of his beloved wife Elizabeth in 1761, John Gregory was prompted to collect a series of letters for his two daughters, reflecting on how they should behave, and conduct themselves in society in the event of his demise, now that they were lacking in a mother to teach them all the rules of courtship and proper public behavior (James Gregory “An Account” 33). Gregory never intended for these reflective musings to be published, though he should have known better. In 1772, he published "Elements of the Practice of Physic, for the Use of Students" as a work "intended solely for his own pupils, and to be used by himself as a text-book to be commented upon in his course of lectures," but of course it became a well-respected textbook in its time (James Gregory "An Account" 65). 
It was Gregory's oldest son James who got his own father's "Legacy" published after his death in 1773 . When published in 1774 , the small (for a conduct book) manuscript went through numerous re-printings, and several re-issues because of its dazzling popularity..$^{72}$ In 1792, Mary Wollstonecraft would go on to quote extensively from the document, taking Gregory to task (as well as Fordyce) in A Vindication of the Rights of Woman. Gregory's text vacillates between several ideas: there is a back and forth between valuing appearance and essence, there are reminders to his daughters that it's very important that they appear virtuous to a man, but it's most important to be virtuous, but what a man thinks matters a bit more.

\section{Gregory's Grieving Introduction}

Mary Wollstonecraft uses A Vindication to analyze other conduct books, so indirectly she is offering advice on right behavior, and education the same way that Gregory is. John Gregory's Legacy begins with a disclaimer-preface by his son, claiming that the "tender father" was in a "declining state of health" and he was writing solely for the "instruction of his daughters, and not intended for the public" (James Gregory, "Preface" v). Of course, this recalls Sarah Pennington's opening to her Unfortunate Mother's Advice from the first chapter of this dissertation. Like Pennington, Gregory is worried that the lack of a maternal figure will be of material harm to his daughters, for he was at the time of the writing, "sole parent, death having before deprived the young ladies of their excellent mother" (James Gregory "Preface" vii). We are supposed to trust Gregory's ethos, from his experience, and

\footnotetext{
72 William St Clair notes the explosive popularity of Gregory's Legacy, calling it, and Chapone's Letters on the Improvement of the Mind as instant canonical classics. Apparently their "prices fell, their print runs soared, and they became boxed in" sets that sold together (131).
} 
his very clear paternal care and outright worry for the fate of his daughters that they would not marry well, or not marry at all. He wrote these "tracts" as his son calls them for several reasons, including to "improve the taste and understanding of the reader" as well as to "mend his heart" and "to point out to him the proper use of philosophy, by shewing its application to the duties of common life" (James Gregory "Preface" ix-x). With a text so clearly designed to instruct, and to solve problems of education, the crisis that Gregory saw was apparent.

Gregory is not an idealist, and he clearly writes from a state of depression and grieving after the death of his wife. He reminds his daughters on the first pages of his letters, that he knows "mankind too well. [He knows] their falsehood, their dissipation, their coldness to all the duties of friendship and humanity" (Gregory 2). His only real hope is a secret one, that the virtues of the dead mother "will entail a blessing on her children" that, along with his writings, might work as a charm to protect them (Gregory 3). Doctor Gregory also knows that this method of communication is flawed, which he implies when he says that if he were to die even sooner, before his girls have grown up, the letters must be received in this very imperfect manner-the last proof of [his] affection" (Gregory 4). These letters, whether public or private, really don't work as well as an actual living person acting as a guide, a teacher or a mentor to a young person when they start out their lives. And Gregory doesn't delude himself, at least not in the introduction to his piece, that the advice that he dispenses can really be perfected over time, either. There are "many nameless delicacies, in female manners, of which none but a woman can judge" (Gregory 5). Gregory claims to be "at the greatest loss what to advise you in regard to books" in a way that Hester Chapone, and even Fordyce are not (Gregory 53). Despite being a man of faith, 
he almost has a doomed tone in his writing, as if he is aware that this is a failed enterprise. Gregory will immediately posture himself as an expert after this lone disclaimer, but at least he gestures towards that disjunction in how each gender experiences the world. ${ }^{73}$

A reader is supposed to trust Gregory more as a father, and as a writer and rhetorician, because of his tragic loss His willingness to acknowledge what he does not know about female manners, and his use of self-deprecating rhetoric in these two sections cements his ethos. He sets himself up for failure, but he creates a performance of selfdeprecation that's actually self-authorizing. He claims to be the only man in the world "who has no desire in flattering or deceiving" his daughters and will therefore speak honestly and from his heart (Gregory 6). That is a self-authorizing statement that Gregory gets away with, because he is painting himself as a devoted father. In fact, it is an instance of the author popping up, when the reader might expect the father, as Wollstonecraft claims can happen in Gregory's work (Wollstonecraft 171).

That disjunction between women and men is never as clear as when Gregory complains about the "natural vivacity, and perhaps the natural vanity of [women's] sex in comparison to men" (Gregory 12). This argument is made by other authors of this time period, including Fordyce (and mocked by the likes of Jane Austen, through her characterization of Mr. Collins, as I have discussed previously). When she is directly addressing Doctor Gregory, Wollstonecraft takes exception to how Gregory advises his daughters to "give the lie to her feelings" (Wollstonecraft 94). She believes that if Gregory's

\footnotetext{
73 Chapone lists out the way that that social life is gendered, Pennington attempts to do the same, but Fordyce completely disregards this difference and claims to be an expert on the female sex merely because he is a religious man.
} 
wife were alive, this advice would not be given, since "no sensible mother will restrain the natural frankness of youth by instilling such indecent cautions" (Wollstonecraft 94). A mother would not be telling her daughter not to express herself. This advice subordinates the female body to the judgments and gazes of men. But whether or not the advice is given, it is advice based on outward behaviors, not inner emotions. Wollstonecraft fails to see how her own ideas are focused on outward behavior. She relies on ranting lists of what is wrong with how women are perceived complaining that women have "only learned to please men, to depend gracefully on them" without telling the reader what the alternative might be. Her arguments may not be frivolous, but they are superficial.

This weakness of sentiment that Gregory finds so charming, is toxic to Wollstonecraft. Wollstonecraft's appeal to women is for them to become strong in both mind and body (73). In contrast to the edicts of Hester Chapone, who develops a course of study for women to engage in, and who tells them to consult a parent or a friend to clarify confusing ideas, Gregory advises his daughters to "avoid all books...that tend to shake your faith on those great points of religion which should serve to regulate your conduct." Women should never "perplex" themselves with those great theological ideas that the religious minds have given the world, but instead, to treat all such confusing things, with "silent and becoming reverence" (Gregory 13-15). Gregory wishes to raise good daughters, but his first point is that they appear to be good daughters, continuously implying that they have good characters, but that how the world of men sees them matters just as much as their innate goodness. She is unable to offer as much concrete educational advice as Chapone, but repeatedly calls for young girls to be educated in matters of substance, not just in pleasing manners (Wollstonecraft 131, 149). 
There are many practical elements of education that Wollstonecraft would like to remediate, or at least change. She complains about the state of boarding schools, which cultivate too much "familiarity" between women, and lead to unhappy heterosexual marriages later on (205). She claims that the only way to remove these deficiencies within education are to first, "contrive some way to combine public and private education" and then to find a way to educate the sexes together so that they learn how to relate to one another $(242,250)$ Only when this happens, will virtue "prevail" in society, because "the virtues of both sexes are founded on reason" and the" affections common to both [sexes] are allowed to fain their due strength by the discharge of mutual duties" (250). But she is depicting the ideal, and until some of these changes are enacted, education in society is set up for failure, because women's education is reliant on the acquisition of superficial talents.

There is plenty that is inauthentic in general education. Protocol and manners are odious to Wollstonecraft. She compares the education of women, and the education of soldiers, when she says that they both "acquire a little superficial knowledge, snatched from the muddy current of conversation" but then the male soldiers can mix with many classes of people, and live out in the world in the way that women are never allowed to do (Wollstonecraft 89). For the most part though, solders are taught to be gallant, and to please, the same way that women are, just with more resources and recourses available to them, if their education doesn't exactly work (Wollstonecraft 89).

As subjects of the male gaze, women must be careful never to expose themselves to rhetoric that could lead to a sexual fall. Gregory warns his daughters that, "Wit is the most dangerous talent [they] can possess. It must be guarded with great discretion and good 
nature" (Gregory 30). Double entendre, and any talk of sex, or romance, however veiled, is "shameful", and, "highly disgusting" to any man who is listening (Gregory 34). Even if the men in the room are indulging in impolite fantasies about the bodies of the women in the room, the women can never ever own that that is happening. Intelligence itself might be a real danger to Gregory's daughters. He warns them to be, "ever cautious in displaying [their] good sense" because, "It will be thought you assume a superiority over the rest of the company" (Gregory 31). By the rest of the company, Gregory naturally assumes the men in the room, and reveals how frightening an intelligent woman (and implicitly a company of like-minded women) is to a traditionally patriarchal man.

In case his daughters were balking at such advice (as the contemporary reader most likely is) Gregory goes out of his way (as Fordyce does) to assure women time and time again, that, "A man of real genius and candour" will always see the best in a woman's character, regardless of her physical appearance (Gregory 32). He will assume that the woman who has any intelligence at all, will have many other gifts, and that will work to their advantage when a man decides to make a woman his wife. Therefore, faking dumbness through a somber and silent demeanor is clearly the best way to behave around men, at least for Gregory. Pretending to be unintelligent but kind-hearted will get Gregory's daughters the perfect husbands.

The difference between a woman who appears eligible for marriage, and a woman who is emotionally prepared for such a commitment continues to be a problematic difference for Gregory, because as with Wollstonecraft, his greatest concern for his daughters is with the appearance of good behavior; i.e. the performance of virtue. When he 
warns them that they might be reproached for their grave silence, by being guilty of "prudery," he reminds then that prudery is usually meant as, "an affectation of delicacy (Gregory 35). But then he admonishes his daughters, that he does not wish them to "affect delicacy" as a set of mannerisms, but instead, he wishes that they would, "posses [sic] it" (Gregory 36). And generally he concludes it is better, "to run the risk of being thought ridiculous than disgusting" (Gregory 36). He reminds his daughters to have a "sacred regard to truth" but then in the same section to behave with "great ease and opennes [sic] in [their] conversation" (Gregory 37). He's asking the impossible. ${ }^{74}$ Conventional manners require a certain amount of behavioral falsehoods and pretense, yet he cannot reconcile that with the true goodness that he wants his daughters to possess. In passages like this, Gregory shows that he will never understand what it means to be a woman, but he also disavows his own understanding of how societal behaviors have been created by men.

\section{Wollstonecraft and Gregory}

Wollstonecraft's critique of Gregory becomes clearer while reading Gregory's text. When a woman is dancing, Gregory claims that a woman "should dance with spirit; but never allow [herself] to be so far transported with mirth, as to forget the delicacy of [her] sex" (Gregory 57). Such vivacious dancing might make a woman appear unfeminine, and heaven forbid that should happen, because then she might not have another dancing

\footnotetext{
74 There is a grave, silent young woman who vows never to "act" as anything other than the good girl that she is, is presented in fiction. Fanny Price of Jane Austen's Mansfield Park might be the ultimate conduct book girl. However, Fanny is consistently upstaged by the worldlier, sexually provocative Mary Crawford, and loses her own heroine-status in the novel at times, to Mary. Austen is believed to be doing a satire of what conduct books do to young women in this text, but Fanny is still rewarded at the end of the novel with marriage to her beloved cousin, and Mary is still unmarried, so there are most likely many layers to Austen's satire.
} 
partner at that ball, or any other. While he doesn't condone a young, innocent woman enjoying a party, he warns about what might happen if "a girl laughs with all the simplicity of unsuspecting innocence" as Burney's Evelina does at her first ball, when she is solicited for a dance by a fop. But Gregory does warn that men will think that such a woman knows, "more than she should" and by being in on a crude joke, might be advertising herself as sexually available (Gregory 59). His fears for his daughters' reputation are clearly grounded in the world he has experienced as a man, and he has pretty much no faith in human nature, but this fearfulness is a common trope in all of the writers of conduct literature I have analyzed. The knowledge that the text will inevitably be misread leads to a fearfulness of the reader's judgments, and a fear of the public readership at large.

Gregory fears that his daughters will be harmed by men, and that they might then become unmarriageable. He worries about them being out in public. When he talks lastly about love, marriage, romance and attraction, he argues to his daughters that he does not think, "public places suited to make people acquainted together" (Gregory 113). While he knows that it is necessary for his daughters to live in the world, he is not very enthusiastic about the prospect, because the world appears to him to be such a dangerous place to be a woman. And his daughters are at such a disadvantage, because they have lost "the only friend that would never persecute you" in the being of their mother, now dead" (Gregory 116). The rest of the world will be an unkind place for them, because for Gregory, after a mother's love, nothing in the world will ever feel pure again.

Concluding his text, Gregory repeats his warnings to his daughters not to marry for money or social standing, or even romantic love, but to marry for esteem and respect of 
their partner. As Wollstonecraft will also argue, "marriage, indeed, will at once dispel the enchantment raised by external beauty" (Gregory 129). Sex will enervate, or coarsen the sensibilities, once it has defiled them. But Gregory can incorporate the hope of a father, that, "the virtues and graces that first warmed the heart" will keep the interest of a man long enough for him to propose (Gregory 129-130). The daughters do not need to be virtuous, but they do need to appear virtuous.

\section{So-Called “Rational” Creatures:}

For Mary Wollstonecraft the weaknesses of the body must be overcome by the strength of the mind, while the habits of good conduct will, for Wollstonecraft, be evidence of essential virtue. However, she is simply laying out another code of behavior for women to follow in public and in private, to replace the condescension of the patriarchal writers of women's conduct literature. Women's education has been, according to Wollstonecraft, more attended to in her recent past, but women are still regarded as the "frivolous" sex, and she introduces her text, by claiming that she wants to avoid "fabricating the turgid bombast of artificial feelings, which, coming from the head, never reach the heart" (Wollstonecraft 74).

Wollstonecraft's ideal woman is married in a love match, but not losing "sight of prudence," she sees the fruits of her labor in her dedication to mothering, and at the time of her death has the satisfaction of seeing her children embody her good behaviors and take them on as "habits" (Wollstonecraft 119). All that Wollstonecraft is able to declare is that her contribution to society can only be measured in these "habits" that her children learn. These habits are supposed to connote internal virtue that is based on good principles, but 
she gives no examples of this inner life. She would like for the head to be stronger than the heart, and she would like for the appearance of virtue to be the equivalence of virtue, but her text does not get there. She still claims that "all writers who have written on the subject of female education from Rousseau to Doctor Gregory, have contributed to render women more artificial, weak characters, than they would otherwise have been; and consequently, more useless members of society" (Wollstonecraft 87).

For Gregory, physical desire is an unwelcome sensation. He argues that "violent love cannot subsist, at least cannot be expressed, for any time together on both sides; otherwise the certain consequence, however concealed, is satiety and disgust" (Gregory 88). For Wollstonecraft, "Sexuality depends on a depravity of appetite that brings the sexes together, a distasteful activity that weakens the frame and coarsens the spirit" (Todd "Introduction" xxiii).

Wollstonecraft does want for women to be fit, and healthy. In that way, Gregory's emphasis on physical health for women dovetails a little with Wollstonecraft's ideas on education, when he recommends "those exercises that oblige you to be much abroad in the open air, such as walking, and riding on horseback" (Gregory 48). But he also cautions his daughters against advertising their strength, because men, "so naturally associate the idea of female softness with a correspondent delicacy of constitution, that when a woman speaks of her great strength, her extraordinary appetite, her ability to bear excessive fatigue, we recoil at the description in a way she is little aware of" (Gregory 51). Wollstonecraft should be shouting at the reader here, again, when she says that "the woman who strengthens her body and exercises her mind will, by managing her family and 
practising various virtues, become the friend, and not the humble dependent of her husband" (Wollstonecraft 95).

In her more repetitive verbal movements, Wollstonecraft argues again and again that love is not the proper foundation of marriage, because love "from its very nature, must be transitory" (Wollstonecraft 95). It is the course of nature, that "friendship, or indifference invariably succeeds love" (Wollstonecraft 96). She would prefer that it be friendship, but she has borne witness to too many marriages where indifference won the day, after sexual passion had ended.

Gregory has considered the female sex, "not as domestic drudges, or the slaves of our pleasures, but as our companions and equals" which places him in relatively revolutionary territory, along with Wollstonecraft (Gregory 6). However, this line of politeness is common among misogynists, and as a man, pleasing men is still the most important goal for Gregory. His primary endeavor is to "point out those virtues and accomplishments which render [his daughters] most respectable and most amiable in the eyes of [his] own sex" (Gregory 8). After all, unlike men it seems that women are forced, more often than not, to "bear [their] sorrows in silence, unknown and unpitied. They must often put on a face of serenity and chearfulness, when [their] hearts are torn with anguish, or sinking in despair" (Gregory 11). Gregory just considers this to be the way that things are. While he doesn't appreciate the forced stoicism that British women ${ }^{75}$ must endure he

\footnotetext{
${ }^{75}$ Gregory diverges from several other conduct book writers, including Hester Chapone, when he says that his daughters should never be friends with a married woman, "especially if she lives happily with her husband": the daughter might learn something about sex, and her mind might become defiled (Gregory 69).
} 
merely claims it as one of nature's laws, that women are forced to obey. For Wollstonecraft, however, these sorts of comments provoke ire. She calls his order for a wife to never reveal to her husband the depth of her affection, "absurd" (Wollstonecraft 95).

Like Gregory, Wollstonecraft doesn't necessarily believe in love. She claims that "once a husband ceases to be a lover-and the time will inevitably come, [the wife's] desire of pleasing will then grow languid, or become a spring of bitterness; and love, perhaps, the most evanescent of all passions, gives place to jealousy or vanity" (Wollstonecraft 93). Gregory shows that he is no master of love either, when he claims that what people, and women in particular call love, "is rather gratitude, and a partiality to the man who prefers you to the rest of your sex; and such a man you often marry, with little of either personal esteem or affection" (Gregory 80). Considering the ideal of his apparently perfect marriage to his dead wife, this is a cynical version of Gregory that is presented in this part of his manuscript. While Gregory has been fearful, paranoid, patronizing, and condescending, he doesn't usually veer into such cynicism. But the reader is left wondering if love can ever exist for Gregory, and if it ever has in the past.

Critics have concluded that Mary Wollstonecraft is very inconsistent in her argument especially about human sexual desire, and passion. She "was rigorously antagonistic to the claims of sex as a grand mover of human action" (Todd "Introduction xxii). Consequently, the, "asexual rational woman of The Rights of Woman has little on the emotional and physical side to do but suckle her baby and make sure that she does not overfondle it" (Todd "Introduction" xxii). As a grand lover of the Enlightenment's ideal of the reasoning mind, and in treating that as the grand mover and shaker in the world, "there 
is little room for sexual activity in the energetic life" (Todd "Introduction" xxii).

Wollstonecraft uses $A$ Vindication of the Rights of Woman as a chance to list out all of the problems she sees in the world, but her solution is tied to manners: it is to treat women like rational people, even if you do not believe that they are. Good conduct then, is not a marker of virtue, but a marker of public politeness, or manners.

\section{Conclusion:}

Doctor John Gregory never intended for his work to be published. As James Gregory, son of John points out as justification,

“A father's zeal for his daughter's improvement, in whatever can make a woman amiable, with a father's quick apprehension of the dangers that too often arise, even from the attainment of that very point, suggest his admonitions, and render him attentive to a thousand little graces and little decorums, which would escape the nicest moralist who should undertake the subject on uninterested speculation" (James Gregory “Preface” vi-vii).

Gregory's devoted attentiveness to his daughters, and fears for their well-being betrays that he does not have complete faith in the genre of conduct literature to create virtuous women. Many conduct writers seem to struggle with this issue. They seem aware that their writing will not be completely successful on their terms, even if it is successful to the terms of their readers. That anxiety over intention is present in all of the texts that I have analyzed in this dissertation. But now, it's an issue not of intention versus reception but an issue of intention versus publication.

It's true that as the son of a famous doctor, James was, "encouraged to offer this Treatise to the Public, by the very favorable reception which the rest of his father's works 
have met with" (James Gregory “Preface” viii). But his father's textbook was also not intended for publication, it was just meant for his students. But Gregory's son made money off the text, which went through many reprints and republications. And his sister Dorothy, one of the intended "daughters" of the Legacy, did marry eventually, but only after she became a noted bluestocking who frequented the intellectual Salons of the likes of Elizabeth Montagu. ${ }^{76}$ Montagu helped raise Dorothy and let her finish her education, until she decided to marry a penniless man for love and Montagu cast her out forever. Dorothy was not following the edicts of her father's Legacy at all after his death, but relied on her own education and intelligence, marrying for love and even passion in the face of her unofficial guardians. As usual, the intended recipient, or addressee of the eighteenthcentury open letter does not have to obey the advice in the public sphere and leaves the advice-text open to the reader's judgements.

Wollstonecraft offers earnest praise of Gregory's, "easy familiar style [which] is particularly suited to the tenor of his advice, and the melancholy tenderness which his respect for the memory of a beloved wife diffuses through the whole work, renders it very interesting" (171). She did not have the privilege of a good attentive father and pays Gregory honor. But Wollstonecraft also notes that he is writing with a very particular audience in mind, and with the intent to pull at their heartstrings. Even though he might have not intended for the publication of his work, "there is a degree of concise elegance conspicuous in many passages, which disturbs this sympathy" (Wollstonecraft 171).

\footnotetext{
76 Other writers I have discussed, including Hester Chapone, Hannah More, and Frances Burney also attended Montagu's Salons around the same time. They were all part of the same intellectual community and were all interested in the epistolary form of narrative, and the rhetoric of advice, as seen in my previous chapters.
} 
Gregory's intention in writing is clear to Wollstonecraft, but she sees occasionally the intention of Gregory's son, the publisher to sell copies of the text sometimes working in contradiction to the paternal tone of the advice. Wollstonecraft so easily sees the contradiction in the genre of advice, as long as that advice was written by others. She loses that objectivity in her own work. Mary Wollstonecraft's focus on good habits of behavior as an alternative form of conduct offers an incomplete solution to the problems of the patriarchy, since it doesn't provide nearly enough concrete solutions to situations that women find themselves in, within their social structures and hierarchies.

Soon after the Rights of Woman was published, Wollstonecraft would meet Gilbert Imlay, and give birth to a daughter, Frances. ${ }^{77}$ Three years later, after Mary Wollstonecraft's marriage, and death in the birth of her daughter Mary in 1797, her husband published her Memoirs, which, though written about her, are written in her husband's voice, and revealed all the details of her sexual affairs and illegitimate child. This effectively damned Wollstonecraft's literary reputation well in to the twentieth century. The problem of publication lies, as it does with Gregory, with the survivors of the family. So we see another similarity between Wollstonecraft and Gregory; posthumous publication was the making of them, and also their undoing. Both authors' reputation as moralists was put in the hands of familial and domestic forces that outlasted them and helps to provide the afterlife of the conduct literature project. Intention and publication diverge in the realm of the advice genre. No reputation is completely safe when familial desires come in to play,

\footnotetext{
${ }^{77}$ Frances Imlay committed suicide when she was twenty-two. She had almost no memories of her mother Mary Wollstonecraft, who died when she was three years old.
} 
whether these are desires for money or fame, or the desire to pay homage to a beloved relative who has died. Neither Wollstonecraft nor Gregory, despite their desire to dispense advice, was capable of controlling their own legacies. Instead, their intended authorial purpose to advise was forever clouded by readers' reception and judgments of their textual product. 
Epilogue: Conducted Beyond

\section{Dear Prudence:}

The rumors were true. Emily Yoffe, also known as "Prudence" of the weekly advice column Dear Prudence in the online magazine Slate, would be hanging up her advice-giving hat at the end of November 2015. Her position would now be filled by Mallory Ortberg, coeditor of the literary feminist blog The Toast. Ortberg confirmed it on The Toast later that same day. She wrote an article called, "I Am Dear Prudence Now Also in Addition to The Toast" on November 9, 2015. The blog entry was tagged with an excited "ahhhhhh" at the bottom of the web-page.

Maybe this was awkward timing, considering that on October $1^{\text {st }}$ of this same year, Ortberg wrote a cutting satire about the kinds of ridiculous questions that Dear Prudence/Yoffe had answered in the last decade, called “Signs You're About To Write A Dear Prudence Letter." The list ranged from the marvelously trivial and oblique ("Your husband is wonderful, but...") all the way towards the alarmingly perverse and specific ("Your stepmother has keys to your apartment and regularly lets herself in to use your bathroom, but she's not willing to pay for your college tuition unless you end things with your racist sugar daddy") and everything in between (the well-known crisis: "Your cat went outside") ("Signs"). But maybe Slate liked the column? Tagged as "advice," it got plenty of hits via social media, and Slate must have realized the broad readership for Ortberg's work. She is the author of Texts from Jane Eyre and wrote an Introduction to a recent Harper Collins edition of Charlotte Bronte's Villette. To deal with the general insanity of write-in calls for help, and to dispense good advice, you need the same traits: a good sense of humor, a very healthy understanding of boundaries, lots of honesty, and deep 
compassion for the human condition. Did Ortberg have enough of those traits to conduct herself creditably as Prudence?

Does any of us?

Now about three years into Dear Prudence, Ortberg is really coming in to her own. What does a grandmother do, when her granddaughter refuses to go see The Nutcracker ballet with her? A very interesting question to be sure, but Ortberg was more interested as to WHY this was such a huge point of contention: "I have so many questions for you —why does your 11-year-old granddaughter hate The Nutcracker? And why is it your only dream to take her to see it? Does she hate all ballets, or just this one?" Maybe the granddaughter actually hates the grandmother, which would be a really tragic piece of that puzzle to fill in ("Roll Over"). And of course, there are the questions about love, loyalty, and the intrinsic complications that come with contemporary life, such as: do I have to allow my partner to impregnate his ex, to give her a baby? And Ortberg's answer is a very kind and considerate: "Of course not!" ("Do It "). What is great about all Ortberg's wry, deft, and occasionally empathic way of handling her job as Dear Prudence is how she sees the community of readers and writers behind each post. She titled her December 21, 2015 chat transcript, "Hi, everyone. Let's fix one another" ("Do It"). After giving due diligence to the writer asking if his partner should impregnate his ex, she did the advice columnist's equivalent of crowdsourcing: "If any queer couples with nontraditional reproductive stories want to weigh in about their own experiences, please do! Has anyone gone the turkey-baster route?" ("Do It"). Ortberg has real ethos, being a queer writer herself, but she has no problem asking for other answers, and therein destabilizing the hierarchy of advice-giver over advice-receiver. Ortberg /Prudence's familiarity with Jane Austen and Pride and 
Prejudice ${ }^{78}$ is evident here in her tone of humility about serious matters. After all, as Elizabeth Bennet says to her sister Jane in Pride and Prejudice, though we all "love to instruct, we can teach only what is not worth knowing" (261).

But it appears that such destabilizing advice works well in our post-modern world. Ortberg's style can be direct, humorous advice-giving, but it also can involve soliciting a range of opinions rather than being prescriptive. While the writing of Hester Chapone, Sarah Pennington, James Fordyce or John Gregory, each as a single voice might not carry as much weight now, contemporary advice columnists have different strategies for addressing the inherent hypocrisy and instability of the advice genre. Mallory Ortberg's Dear Prudence Podcast invites other advice columnists (and former Toast Editors) like Nicole Cliffe, and authors like Roxane Gay to weigh in on the letters that she receives. Her most recent podcast was live, and she fielded issues and from the audience. Out of all the chaos of our day-to-day, probably the first step is acknowledging that it might take more than one person, and more than one authorial voice, or tone to help solve our increasingly complex problems. Mary Wollstonecraft is not on call to evaluate the quality of all of the conduct/advice literature being written in our time. As a result, readers can be reading, evaluating, and judging the advice that's being given to them in real time with the other people who might be dispensing advice. They can cherry-pick what is the most relevant to their lives, and ignore what's less relevant. The overarching crisis, or panic about what unmarried young women will do with their lives is gone. What remains, however, is the

\footnotetext{
78 Ortberg published "Texts from Pride and Prejudice" in the online magazine, The Hairpin in 2013, and it was reprinted in her 2014 book, Texts from Jane Eyre: And Other Conversations with Your Favorite Literary Characters.
} 
intention of the columnist to provide both guidance and help, or at least that is clearly Prudence's intention. Other columnists place a greater emphasis on entertaining the reader, or perhaps disrupting their reader's line of thinking.

\section{Dear Sugar:}

Five years before Ortberg took up Emily Yoffe's Prudence mantle, an anonymous writer introduced herself as the new voice of "Dear Sugar," an advice column of the respected online literary magazine, The Rumpus (Errico 2012). "Dear Sugar" had started as the nom de plume of Steve Almond (who had shortened the name from "Dear Sugar Butt" an affectionate name he had for the editor of The Rumpus, Stephen Elliot, in his emails (Almond 3)). Almond conceived of a different kind of advice column, one that was "irreverent and brutally honest" at the same time (3). As a creative writer, he should have also anticipated the problem that he immediately ran in to, when he also implicitly imagined the backstory for Sugar as "a persona, a woman with a troubled past and a slightly reckless tongue" (Almond 3). So, this ambitious, and rather arrogant premise of starting an advice column was further warped by the fact that to resonate with the people who would writing to Sugar, Almond would have to adopt a different persona, and a separate set of life-experiences possibly along gendered lines. The project wasn't necessarily marked for success. "While I could feel myself locked into the pain of my correspondents," Almond confesses, "more often I faked it, making do with wit when my heart failed me" (Almond 3). The eighteenth-century conduct book writers that I have discussed in my dissertation attempted to give unsolicited opinions on how they think people should behave. In doing so their advice didn't have to be specific, or even substantive. They could rely on the performance of giving advice while posturing as 
mentors or confidantes: doting parents, wise clergymen, and loving friends. Though Almond was receiving solicited letters and not just opining on the page, he would probably understand the impulse to perform and posture as well as Chapone, Pennington, Fordyce, or Gregory. However, because he is a contemporary writer, he could demand to get to the heart of the issues in his letters, and address the problems less politely, and perhaps more immediately or intimately. This means that the act of giving advice as a columnist can be emotionally draining. Your heart might become alive with empathy, but your mind cannot sustain it.

After a year, Almond was burnt out, and he quit writing the column. But he had an idea of who he wanted to replace him: the author Cheryl Strayed. Strayed as Sugar claimed she would offer a combination of "the by-the-book common sense of Dear Abby and the earnest spiritual cheesiness of Cary Tennis and the butt-pluggy irreverence of Dan Savage and the closeted Upper East Side nymphomania of Miss Manners" (Errico 2012). Strayed as Sugar was clearly in the right place at the right time. As Almond tells it, the column that really unlocked Dear Sugar as a literary phenomenon was written in an almost throw-away letter that goes like this:

Dear Sugar, WTF, WTF, WTF? I'm asking this question as it applies to everything every day. Best, WTF (Almond 3)

Sugar's answer was tonally just as tongue-in-cheek, but she diverged from the blasé generalizations of the submission to horrifyingly specific in her response:

Dear WTF, My father's father made me jack him off when I was three and four and five. I wasn't any good at it. My hands were too small and I couldn't get the rhythm right and I didn't 
understand what I was doing. I only knew I didn't want to do it. Knew that it made me feel miserable and anxious in a way so sickeningly particular that I can feel that same particular sickness rising this very minute in my throat. I hated having to rub my grandfather's cock, but there was nothing I could do. I had to do it. My grandfather babysat my sister and me a couple times a week in that era of my life and most of the days that I was trapped in his house with him he would pull his already-getting-hard penis out of his pants and say come here and that was that (Dear Sugar \# 39).

Steve Almond ${ }^{79}$ writes that he saw what Strayed-as-Sugar was doing. As an advice columnist, it is usually not your job to make the giving of advice about your own conflicts and issues, at least when the writer has solicited help for their own concerns. When the advice is unsolicited, authors can choose whether or not to pull from their personal ethos. Hester Chapone references her niece's parents on the first page of the first of her Letters, as good people who will be good guides for the niece. Sarah Pennington shied away from the accusations that her ex-husband had made about her, to preserve what is left of her reputation and her maternal authority over her intended readers: her daughters. James Fordyce uses the tone of a wise vicar, intent upon bettering the lives of his female readers through the goodness of his Christian heart. John Gregory believes it is his life's work to impart good knowledge and wisdom to his daughters, even if that advice is set up for failure. But none of the eighteenth-century writers discussed previously were not writing syndicated serial columns. They exposed their thoughts, desires, and moral codes for the world to see in monolithic epistles, or sermons. While they could be read and understood in pieces, they were given to the public as whole documents, not columns. The reading public

\footnotetext{
${ }^{79}$ Almond solicited Cheryl Strayed to become Sugar after he quit the job, because she had written a beautiful novel Torch, and was the author of his one and only fan-letter. Needless to say, she took the job.
} 
consumes advice columns differently than they might consume a conduct book, regardless of whether or not the author's intentions, or writing processes align.

As Almond says, the way to write an advice column is actually pretty simple: make your advice all about the person soliciting the help, "dispense the necessary bromides, [and] make it all seem bearable (Almond 5). Instead, Sugar uses this letter to stake her claim as to what an advice columnist could do, as she attempted to rhetorically slap awake the callow soul who had written to her, providing a teachable moment, and highlighting the hypocrisy behind all advice-giving columns: no imperfect person can give perfect advice. Sugar had developed a voice that was, "entirely her own: an advice columnist who spoke through frank personal experience" (Errico 2012). In this case, this ugly personal experience that Strayed had had as a child was a means to address the meat of the question: it was a senseless abuse of a child, and the damaging reverberations Strayed continues to feel. But so many of the most painful moments of our lives will feel like they don't make sense. As Sugar would tell, "Dear WTF":

"There was nothing the fuck up with that and there never will be. I will die with there never being anything the fuck up with my grandfather making my hands do the things he made my hands do with his cock. But it took me years to figure that out. To hold the truth within me that some things are so sad and wrong and unanswerable that the question must simply stand alone like a spear in the mud" (Dear Sugar \#39).

Steve Almond pointed to the brilliance of such a lesson. After all, senseless pain awaits all of us in life at one point or another. "Life," Almond says, isn't "some narcissistic game you play online. It all matters-every sin, every regret, every affliction" it matters even if it feels like our trauma isn't meaningful (Almond 4). Strayed took that point even further. Soon after the death of her mother, Strayed/Sugar recounts finding a baby bird that had fallen out of 
its nest, and was slowly, torturously dying. She knew she had to do something, so she put the baby bird into a paper bag, and smothered it:

Nothing that has died in my life has ever died easily and this bird was no exception. This bird did not go down without a fight. I could feel it through the paper bag, pulsing against my hand and rearing up, simultaneously flaccid and ferocious beneath its translucent sheen of skin, precisely as my grandfather's cock had been. There it was! There it was again. Right there in the paper bag. The ghost of that old man's cock would always be in my hands. But I understood what I was doing this time. I understood that I had to press against it harder than I could bear. It had to die. Pressing harder was murder. It was mercy. That's what the fuck it was. The fuck was mine (Dear Sugar \#39).

Strayed is writing about real, universal human feelings, even if not universal experiences. It was a universal experience, because her little broken-necked bird suffering, "would've been unbearable for me to witness at any time, but it was particularly unbearable at that moment in her life because her mother had just died. And because her mother was dead, Strayed, felt like she was pretty much dead too. Strayed was dead but alive. And she had a baby bird in her palms that was dead but alive as well" (Dear Sugar \#39). The ghost of the dead or absent mother haunts both Sarah Pennington's and Doctor Gregory's conduct books, and is in some ways the main impetus behind the writing of both of those texts. But Strayed focuses on the senseless tragedy of losing a parent, and not in using her advice as a maternal substitute.

So, Strayed must remind her writer, ...the fuck is yours too, WTF. That question does not apply "to everything every day." If it does, you're wasting your life...Ask better questions, sweet pea. The fuck is your life. Answer it. 
It was after this post that the Dear Sugar column really took off, and over the next couple of years, she increased her following to around fifteen thousand readers, Facebook, and Twitter followers (Errico 2012). Steve Almond says the reason Sugar emerged as a pop cultural phenomenon, is because she is offering "radical empathy" in a world that is "dying of loneliness" (Almond 6, 5). If empathy is to see and understand the feelings of others, then Sugar is employing empathy by mirroring of their feelings of others through highly personal anecdotes. However, it's more than that, because Strayed also is a lyrical writer with such a powerful voice. The genre of advice literature might be an impossibility, but Cheryl Strayed finds the artfulness in this impossibility. She might not be able to get her reader to "answer" their life's WTF-moments, but she attempts to see these painful universals as a chance to find beauty, and hope.

When Strayed outed herself as Dear Sugar in a New Yorker column of 2012, Sally Errico claimed that she is the kind of columnist whose responses went from advice to essay and back again (Errico 2012). She is able to "transmute the raw material of the self-help aisle into genuine literature" 80 through introspection and intimacy (Almond 6). She tells Sally Errico in The New Yorker, she has always written the column, "as if I were a naked woman standing in a field showing you everything but her face" because that's how she's written everything in her life (Errico 2012). Strayed's book, Tiny Beautiful Things: Advice on Life and Love from Dear Sugar, is an anthology of her own columns from The Rumpus, which

\footnotetext{
${ }^{80}$ Of course, advice books have always been "literature," but I am willing to forgive Almond for this oversight, because so much of what is considered advice is categorized into specific genres for specific audiences before it is even published. And as we have seen in my preceding chapters, this has been the case for almost three hundred years.
} 
couple autobiography with advice that might interest the middle-class "good girl" of the eighteenth century. According to Strayed, "one of the most fascinating things about writing the column has been the opportunity to explore the direct address in a public arena" (Errico 2012). Direct address of course, is the habit, or obsession of all of the conduct book writers I have looked at over the last four chapters. Each conduct book was written for some "good girl," or some group of good girls listening to the advice together. Chapone writes to her niece, Pennington to her daughters, Fordyce to the ladies of his parish, and Gregory to his daughters as well.

Dear Sugar grew to popularity on the internet, and only after anthologizing her work did her columns appear with ink on paper in Tiny Beautiful Things of 2012. The digital world is a shadowy desert canyon, an anonymous abyss of information and opinions, rolling in a nameless vortex. What makes Dear Sugar, and Dear Prudence so remarkable is the fact that people in their frustration and even despair shout into the abyss of technology, and the abyss answers back. Reading conduct literature can console the contemporary reader. Though the advice itself might be unsought and unheeded, the advice itself establishes that are not nearly as alone as we might feel, even in Almond's world that is dying of loneliness. This knowledge can be an abrupt realization; that it is our life to create or destroy, but also very comforting. Even if we don't follow the advice of a conduct book writer, we read their work for other reasons, including for amusement, like with Dear Prudence, or for the beauty of the writing style, like Dear Sugar. The eighteenthcentury reader might also be reading advice but not reading for the advice. Like their contemporary counterparts, they might see themselves in the subject of such advice books, 
but they might not, especially in the texts that are so focused on attaining a good marriage that are therefore more devoid of empathy.

\section{Dear Rules Girls:}

Perhaps the most failed advice-giving project in the genre of contemporary advice was written, not in a column, but in a book, like its eighteenth-century predecessors. In 1995, Ellen Fein and Sherrie Schneider published a book of dating do's and don'ts that maybe the reader's "grandmother" would have told you to follow (Fein and Schneider, "Introduction"). Operating under the assumption that men love the chase more than the object of conquest, The Rules: Time-tested Secrets for Capturing the Heart of Mr. Right was set up to guide a woman on how to be chased (and chaste) until it worked out in her favor with a marriage proposal. Culled from the advice of their own mothers, there are several "truth[s] universally acknowledged," (though they don't cite page 1 of Austen's Pride and Prejudice) that Fein and Schneider are tapping into.

Understandably, the authors and their work have had to encounter tremendous criticism of their writing, because their advice is so backward-looking, and clearly born of neurotic desperation. Is it culturally backward for the man always to pursue the woman? And more importantly, what do women do once the marriage has taken place? Thirty-two of the thirty-five "Rules" Fein and Schneider have, are for pre-marriage. There's a reason that Pride and Prejudice, Pamela, and Evelina, the three novels that I have addressed in this work, all end a few days, weeks, or maybe a month after the wedding has been achieved. The novelists cannot point to a happy universal after wedlock. When advising young women in the conduct books I have analyzed, Letters on the Improvement of the Mind, An Unfortunate Mother's Advice, Sermons, and A Father's Legacy, all address women before 
marriage, and advise them how best to attract their husbands. It's as if as soon as a woman is married (and according to the most traditional forms of understanding, has a knowledge of sexuality) she immediately knows everything she will ever need to know. Once a woman is married, she doesn't need advice, according to the most traditional way of looking at a marital relationship.

The authors of the conduct books I have analyzed are women who were 1) an unmarried woman at the time of writing (Chapone) 2) scandalously separated from her husband or divorced (Pennington) 3) an unmarried man at the time (Fordyce) and 4) a widower (Gregory). However, these writers were free to dispense advice, and information about their relationships, if any, to defend or criticize themselves, with the distance from matrimony that their lives had provided them to that point. It seems that traditional gender advice must have this distance, so the best giver of advice is one who doesn't currently have the experience they are talking about. The rhetorical authority of eighteenth-century advice works in abstraction, not empathy. It can only exist if the author is forced to be impersonal, because their experiences, and the socially acceptable manners of the day do not let them relate to their readers specifically. What Fein and Schneider do is to go back to these almost impersonal abstractions to gloss over the individualized experiences of their readers, and instead focus on the one and only prize: a husband.

This old-fashioned notion that women should, "play hard to get" to get their man is just that: old (1). These "time tested" ways of winning a man's heart are so old that the authors must provide a disclaimer, that The Rules, at first blush, are too " 50 ' $\mathrm{s}$ " for anyone to take seriously (2). Perhaps the reader might think these rules are "crazy" but not to worry, the authors did too, until "much heartache" forced them to realize that playing hard 
to get got them the male attention they so desperately wanted (and perhaps as neurotics, needed as well) (2). But for Fein and Schneider, "Nineties women," products of secondwave feminism, and taught to dream of being "president of the company, not the wife of the president" were not "schooled in the basics-The Rules of finding a husband or at least being very popular with men" (2). Of course, that's what happens after women are taught to be ambitious and self-reliant. And the nineties, before the anonymous void of the internet really took hold, they were instead complaining to their friends, and the good, married ladies.

Despite any initial misgivings about how dated The Rules might be, Fein and Schneider "got bolder" and "began to talk louder about them" because it turns out that the Rules worked for them (2). Americans are part of a results-driven society. When married women began to talk about how happy they were in marriages that according to Fein and Schneider were, "real, lasting marriage[s] not just loveless mergers" and old friends were talking about how they had found their husbands by playing hard to get, the authors realized that The Rules were part of the unspoken mainstream practices implemented all over the place. Fein and Schneider want each woman to have what is advertised by the American cultural ideology of a fulfilling and supportive monogamous relationship to last a lifetime. The writers promise that if the reader follows The Rules, they will have a “'...happily ever after.' A marriage truly made in heaven” (6). Reductive? Yes. But marketable? Absolutely.

There will always be conscientious people, voices of reason-or in Fein and Schneider's mind detractors or nay-sayers—and those who tell Fein and Schneider that The Rules prevent them from, "being themselves or having fun" when they are dating (9). 
What's scary is that Fein and Schneider don't deny this. But they say, "Has wearing your heart on your sleeve ever gotten you anywhere" (10)? Just like their eighteenth-century predecessors, Fein and Schneider do not endorse their reader behaving authentically. It's perfectly $\mathrm{OK}$ to endorse duplicity and inauthenticity in the short term, if it helps the woman get her man. And Fein and Schneider paint a lovely, completely idealized, abstract picture of what it will look like, when The Rules work. They encourage their readers to "Think Long Term. Imagine a husband you love, beautiful sex, children, companionship, and growing old with someone who thinks you're a great catch" (9). Of course, the fantasy they are projecting on to the page relies on ignoring any flaws or real-life problems that consistently spring to mind in rational human beings, the same way that the fairy tale ignores these problems. The thesis of The Rules seems to be: you want the fairy tale, don't you? Then do what we say. ${ }^{81}$ The Rules are no exception. Women are not supposed to desire anything. However, they are programmed to desire marriage. Therefore, this will be the overriding principle that guides their lives, and guides their intake of this advice book, even though the advice in question is at many points, counterintuitive, if not completely insane. The result is a set of guidelines for female behavior with an emphasis on superficiality, and not just physical superficiality, but also the mental and spiritual glorification of the external.

Like those eighteenth-century conduct books written by men, The Rules are all about appearances and perceptions. Rule number 1 is "Be a Creature Unlike Any Other" which means be the very best version of yourself-and if you are reading for the nineties and early two-thousands, is a masterful ego-stroking maneuver. Obviously, you are a

\footnotetext{
81 A Faustian Accord, or "Deal with the Devil," as it is commonly called, is structured to ensure that the victim is not able to look beyond the immediate satisfaction of their first impulse.
} 
woman and you are perfect exactly the way you are! Hooray for feminism! But then The Rules can remind you that you need to be the best person you can possibly be...physically. For these authors, this means hitting the gym, and staying away from sweets if you want to attract a man. They tell women that if they think what matters inside matters more, they should, "think again" (17). As Fein and Schneider say, "you must change your definition of gratification" (16). Instead of finding gratification in high-calorie food for example, find it in exercise that will become a svelte figure and the promise of a date the next weekend. In other words, find it in the validation of other people, not in self-gratification. Always look outside yourself, in order to feel positive inside. So, to get the perfect man (who does not need such external validation) a woman must redefine something in her own life. And the man of course doesn't have to change anything about himself and can continue to be selfsufficient if he so chooses. This is how the world works, according to these authors, who reveal a cynical outlook towards male-female relationships (similar to the fatalistic outlook of Dr. Gregory, whose tone occasionally reveals his project might be set up for failure). But Fein and Schneider try very hard to make this about what's generally good for a woman (and eating sweets or lying on the couch is bad). Coaxing and superficial flattery make up the bulk of their book, and women are condescended to and treated like children, under the guise of the sympathetic-sister-in-arms tone.

Fein and Schneider advise women to always dress in a "feminine" way to remind men that they are women (17). They encourage women to hide their least attractive features behind good clothes, to get a nose job, or dye their hair, and to always, "grow [their] hair long" because "Men prefer long hair, something to play with and caress. It doesn't matter what [the woman's] hairdresser and friends think" (Fein and Schneider 19). 
Moving beyond needing the validation from other people to find gratification, Fein and Schneider seek to remove female communities of opinions from affecting the behavior of women. It now only matters what men think of women. While this makes perfect sense if the only goal in life is to keep the attention of a man long enough for him to propose, there is no way that the community of female friends that the reader as most likely accrued in her lifetime will stand to be treated like a second-string team. The Rules book might work if every woman on earth is following them at the exact same time, or if the reader was surrounded by only like-minded women. If not, Rules-girls are setting themselves up for a lifetime of loneliness. An individual's happiness cannot depend on the life of one other person, if the relationship is in any way healthy. Yet that is exactly what the majority of eighteenth-century conduct books and The Rules both believe. Happiness is entirely a matter of having a good husband. That's all there is to it.

To best attract a man, it is important not only to look your best, but to act your best too. Don't ever act like a man, Fein and Schneider say. When you are out in public, be sure to be feminine, and “Don't tell sarcastic jokes. Don't be a loud, knee-slapping, hysterically funny girl"; instead, be "quiet and mysterious, act ladylike, cross your legs and smile. Don't talk so much" (Fein and Schneider 19). Wollstonecraft would complain that Fordyce made his ideal woman pathetically sentimental, and so will any Rules-girl, as luck would have it. She should not have a personality, for fear of having a bad one. Fein and Schneider must go out and attack women who feel these behaviors are outdated or suppressive, because even though you will probably "feel that you won't be able to be yourself, but men will love it!" (20). Here the reader might be reminded of Doctor Gregory, and Wollstonecraft's anger at 
Doctor Gregory urging his daughters to hide any wit they have in the presence of a man, because the advice is the same, though given in more twentieth-century terms.

But a woman's behavior to a man must not only be placid, non-affronting, and demure. She should also make sure not to be, "cynical, or depressed and tell long windedstories of all the people who have hurt [her] or let [her] down" (Fein and Schneider 20). In other words, if you have sad stories, or are suffering under any mental or emotional anguish, be sure to repress those feelings and thoughts if you want to get a man to propose. This is particularly devastating advice, when you think that if the woman-reader had to chance to reflect on what might be causing any of this grief or anguish in her life, she could deal with it, and then actually make herself happier, and readier to date. Dear Prudence and Dear Sugar might give advice like that: reflect on your choices, better yourself, and you'll be ready to live in the world Instead, The Rules advise you to repress and suppress to get you the man of your dreams. They tell the reader to, "act as if [she was] born happy, and "act ladylike" to everyone (20). Civility, and behaving like a robot, or a "Stepford Wife" will certainly get you the proposal, but to what type of man? And what will the reader do with all those feelings, impulses, and thoughts, when they come shooting out of her one day, as all repressed feelings do at one point or another. Fein and Schneider are quite certain that if the reader follows their Rules, "and pray[s] for patience" then they are sure to "eventually meet and marry the man of [their] dreams" (21).

It is interesting that the writers bring up prayer here. A few writers of the conduct books from the eighteenth-century would agree that prayer works. Fordyce claims that there is nothing better than a sort of subdued prayerfulness to be consistent in the mind of the reader, as just a mental state; it belies a state virtue (Fordyce v. 2, 115). But with a 
strategy that relies on so much duplicity, repression, and making the attention of a man the only thing worth living for, prayer seems a strange strategy. The God of The Rules must work like some genie, willing to grant the one wish of every woman: a husband.

By and large, The Rules advise rarely returning phone calls and other playing-hardto-get methods of keeping the male attention on them. Each woman is to be a "creature unlike any other" because men will not be able to understand her. Since men and women have been taught (even centuries before Reverend Fordyce) that to "read" the other sex was one of the most important jobs of their lives, misreading is still common, especially among the poorly socialized internet generation. People may have trouble telling the difference between a woman who is genuinely not interested (or not interested anymore) who is being polite about it and one who is genuinely interested, and just afraid of appearing aggressive, because that would be "unfeminine."

Fein and Schneider advocate for a jealous man, who gets upset, and possessive. In fact, "It's good when men get upset; it means they care about you. If they're not angry, they're indifferent, and if they're indifferent, they've got one foot out the door" (48). Of course, these behavioral habits can lead to terrible misunderstandings including stalking and issues of sexual consent, not only for women using The Rules, but any person who believes all women are playing similar games even when they are not. Fein and Schneider's approach to getting marriage proposals for their readers also lacks nuance, and they want to beat their ideas over the readers' heads. Though they claim that no woman must keep up the disingenuous charade forever, and they can reveal "more" of themselves after the man has expressed love, it still leaves the onus of good behavior on the woman's shoulders, to appear polite, withholding in a socially acceptable way, and always pleasantly busy. The 
man therefore should feel even guiltier for having such shameful animal desires about the object of his affection, which cannot be conducive to a healthy sexual impulse. None of The Rules relationships can be truly healthy when founded on such shame and repression.

In sexual situations, it's important for a Rules-girl to behave well. If she is a really "good girl, she will passively submit to the man's desire, and should not waste her time verbally demanding pleasure in the bedroom. Instead, she should, "stay emotionally cool no matter how hot the sex gets" because, "most women turn men off not only because they sleep with them too soon, but because stereotypically women are too chatty, even in intimate situations" (82). Instead, by letting the man take the lead and exploring the body, both of them will "have fun and be satisfied" (82). Bravery has no place in the bedroom of the Rules-girl. Being cool, calm and collected might not bring her any sexual satisfaction, but it will please the type of man that is turned on by her being withholding, and that will eventually get him to propose, so the endgame will win out.

As the writers conclude the list of Rules, they reflect on how it is "not necessary to have a high IQ to do The Rules, just a certain degree of determination. In fact, highly educated girls have the hardest time with The Rules," because, "they tend to think all this is beneath them" (120). In this way, The Rules stray far away from any eighteenth-century conduct manual. Even if the woman must hide her intelligence, the writers of the eighteenth-century conduct book saw intelligence as a gift to be utilized, even if only utilized in secret. Both male conduct book authors strongly advocated for a hiding or repressing of the attributes of intelligence. Fordyce warned women against utilizing or appearing to utilize wit, because it makes men feel uneasy and unsafe around them, but he still advocated for a woman to be educated, even if she did not show her intelligence in 
public (Fordyce, v. 1, 77-78 95, 98). To Dr. Gregory, wit is, "the most dangerous talent" that a young woman can possess, even though her intelligence is a gift from God (27). The female conduct book authors were more liberal in their thoughts. Hester Chapone wished for her niece to practice both self-reliance and self-control (Chapone v. 2, 144). Sarah Pennington is vaguer in her advice regarding education, but she attempts to stress over and over again that choosing a good husband requires discernment and judgment (Pennington 52). While not necessarily advocates for higher education (though Chapone was a bas bleu, a bluestocking: or a female intellectual of her time) many of the conduct book writers, and even Wollstonecraft called for a rethinking of female education. But Fein and Schneider see only that when their Rules are followed incorrectly, it is usually by reflective people who can spot the inconsistencies within the text, and the appeals to women's vanity. No, The Rules are not meant for intelligent people, or meant for critical thinkers.

Betty Friedan's The Feminine Mystique of 1961 used chapter one of this text to address "The Problem that Has No Name" to attempt to describe the rise of depression and anxiety in women during the 1950's and 1960's. Though the work itself is repetitive in its musings, what remains compelling to the contemporary reader are the anecdotes about modern marriage and motherhood, such as, “The problem is always being the children's mommy, or the minister's wife and never being myself" (Friedan 23). Clearly Fein and Schneider never read The Feminine Mystique, because they see no need for their reader to self-identify as anything but a woman in search of a husband. They conclude their Rules by reminding women to not talk about what they are doing to their parents, their friends, or their therapists $(130,144)$. Fein and Schneider don't admit that the Rules are a con, they just claim that the Rules were unspoken for such a long time for a reason, and they don't 
want women to face judgement from people that they trust and confide in. Any decent friend or family member will see the signs that their friend or loved one is removing all senses of agency and self from her own being to satisfy a man, and of course if they have an ounce of integrity, they will attempt to help, or intervene for this Rules-girl. But a Rulesgirl, if maniacally focused enough, will ignore their aid and attention, because the only way that she will feel validated is through the attention of the man she will marry.

Suffice it to say, Dear Sugar advises therapy to anyone and everyone whom they think need it, in Tiny Beautiful Things. But as previously discussed, The Rules only really works if everyone is doing them at the same time, and they all buy in to exactly the same ideology, or one incredibly desperate, lonely person is willing to sacrifice parts of themselves, including family and other friendships and relationships to please one man, and therefore gain the status symbol of a marriage. Yet they do so by being completely reductive in their understanding of men. They are denying both the humanity of men, and the humanity of women in the writing of The Rules, and both denials are damaging. Although Cheryl Strayed-as-Sugar is applying advice for the self-absorbed millennial generation, and Fein and Schneider are ignoring that men have feelings (in a misogynist way) they both show that the act of dispensing advice in writing is just as challenging and conflicted as it was in the eighteenth century, and that the genre of advice-giving can be just as helpful and as damning as it was hundreds of years ago. We read conduct literature to pass judgments. Within the confines of someone else's problem, we can feel both comfort and superiority.

\section{Conclusion:}


After describing the work of my dissertation, it was common for me to receive contemporary conduct books as gifts, including How to Be a Lady, by Candace SimpsonGiles, and How to Be a Hepburn in a Hilton World, by Jordan Christy. Simpson Giles provides a list of ways that a "Lady" behaves, such as always returning her voicemails promptly, and always knowing when to leave a party and say goodnight $(66,92)$. Christy takes another tack, through essay-length chapters that remind the reader to, "Keep Your Chin Up and Your Skirt Down," "Choose Your Friends Wisely," and to "Dress to Impress," $(67,87)$. The popularity of such books reminds the reader that giving advice on behavior has never really gone out of style, mostly because the genre remains accessible. The reader might pick up the book without any intention of following the advice, but to be entertained. The most recent of these is Sinead Murphy's 2014 The Jane Austen Rules, which combines Fein and Schneider's ideas about love with readings of Jane Austen characters and eighteenthcentury points of morals and decorum. There are chapters that tell women to speak up, and not act too demure, but to, "Say Something" and captivate a man, as Elizabeth Bennet does Mr. Darcy; but also warns women not to have girlfriends, because after all, Elinor Dashwood was in competition with Lucy Steele for the love of Edward Ferrars in Sense and Sensibility, and Anne Elliot was talked out of an early, happy marriage to Captain Wentworth in Persuasion $(67,81)$. The conduct book would not succeed without the experiences surrounding it that prove the writers are fallible, and their texts can be misread. The loneliness of Chapone's life that led to very abstract advice, the sexual fall, or threat of it in Pennington's anxieties, the misplaced desires of the Reverend Fordyce's obsessions with sex, the grief for what has been lost in Gregory that sets the fatalistic tone for his project, and the frustration of Wollstonecraft, they are what make the conduct book 
readable, not the advice they are dispensing. The reader comes back for more, because they find the stories of misplaced, or abused codes of conduct compelling.

We see again and again how dispensing good advice is self-serving, as Cheryl Strayed needs to affirm her writerly self even as she tells others how to behave; incorporating elements of memoir even as she dispenses her advice. We as readers, just as in the eighteenth century, also take pleasure in this voyeurism. In hearing salacious stories, or in reading terribly damaging advice like in The Rules, we revel in the follies and errors of others. That, along with the jolts of sympathy, or even empathy that the talented advice columnists can generate in telling, re-telling, or empathizing with the solicitor's struggles, are two of the many pleasures that can be derived from conduct literature. So, some of the pleasures of the reading come with a good reading of the text, and others with a misreading, or reading against the intentions of the conduct literature's author who wants us to follow this advice. Perhaps what the contemporary advice columnist is offering readers, however, is the possibility that this intrinsic hypocrisy is not fatal; it is just a symptom of the disconnect between any reader and any writer of any text, anywhere. By embracing the vulnerabilities and instabilities in the stories that the conduct genre tells us about, we can empathize with both the other readers and the writer. In our time, we know that neither reader nor writer can claim infallibility in the genre of the advice manual. By bearing witness to our shared hypocrisy—reading and understanding that the advice we're getting is as imperfect as the person giving it-perhaps we are saving the conduct book from itself. 


\section{Works Cited}

Almond, Steve. "Introduction: I was Sugar Once: Lessons in Radical Empathy," Tiny Beautiful Things: Advice on Life and Love from Dear Sugar. New York: Vintage Books, 2012. Print.

Armstrong, Nancy, Desire and Domestic Fiction. New York: Oxford UP, 1987. Print.

Austen, Jane. Pride and Prejudice. New York: Oxford UP, 2004. Print.

Bander, Elaine. "From Cecilia to Pride and Prejudice: "What becomes of the moral?"” Persuasions On-Line 34.1 (Winter 2013): 1-9. Web. JASNA.1 Sept. 2017.

Barrecca, Gina. They Used to Call Me Snow White, But I Drifted...Women's Strategic Use of Humor. Hanover: UP of New England, 2013. Print.

Belew, Dell. “That 'Damned Scribbling' Girl in Pamela; or, Virtue Rewarded.” The Journal of the Georgia Philological Association (2008): 169-175. Web. JSTOR. 16 June 2017.

Bornstein, Diane. The Lady in the Tower: Medieval Courtesy Literature for Women. Hamden: Archon Books, 1983. Print.

Brewer, David .The Afterlife of Character, 1726-1725. Philadelphia: The University of Pennsylvania Press, 2005. Print.

Bronk, Katarzyna. “'Much, I am Sure, Depends on You': James Fordyce’s Lessons on Female Happiness and Perfection." Studia Anglica Posnaniensia 48:4 (2014): 49-62. Web. JSTOR. 2 Oct. 2014.

Brown, Laura. “Shock Effect: Evelina's Monkey and the Marriage Plot.” The Eighteenth-Century Novel 6-7 (January 2009): 379-407. Web. JSTOR. 7 Aug. 2017. 
Burney, Frances. Evelina. Ed. Vivien Jones. New York: Oxford UP, 2008. Print.

Chapone, Hester. Letters on the Improvement of the Mind, Addressed to a Young Lady. $7^{\text {th }}$ ed. London, 1776. Eighteenth-Century Collections Online Web. 16 Mar. 2014. Christy, Jordan. How to Be a Hepburn in a Hilton World: The Art of Living with Style, Class and Grace. New York: Center Street Hatchette Book Group, 2009. Print. "Conduct" Oxford English Dictionary: OED. Copyright 2018. Web. 2 Jul. 2015.

Davidson, Christina. “"'To Speak As Others Speak": Privileged and "Vulgar" Voices in Evelina, By Frances Burney.” Women's Writing 23.1 (January 2016): 33-52. Web. Routledge, Taylor-Francis Group. 7 Aug. 2017.

Davidson, Jenny. Hypocrisy and the Politics of Politeness: Manner and Morals from Locke to Austen. New York: Cambridge UP, 2004. Print.

De Beaumont, Jeanne-Marie Leprince. Beauty and the Beast. Marie-Michelle Joy Author/Transl. Somerset: Red Robin Books, 2015. Kindle Edition. Downloaded 3 Feb. 2018.

DeGabriele, Peter. “The Legal Fiction and Epistolary Form: Frances Burney's Evelina." Journal for Early Modern Cultural Studies 14.2 (Spring 2014): 22-40. Web. Project Muse. 4 Aug. 2017.

Dicus, Andrew. “The Rude Mass and the Mighty Whole: Agency and Materialism in Mary Wollstonecraft's Political Philosophy." Modern Philology 114.2 (November 2016): 337-358. Web. 15 Sept. 2017.

Dobson, Austin. Samuel Richardson. New York: The MacMillan Company, 1902. Web. 13 Mar. 2018. 
Doody, Margaret Anne. A Natural Passion: A Study of the Novels of Samuel Richardson. New York: Oxford UP, 1974. Print.

---. Frances Burney: The Life In The Works. New Brunswick, Rutgers UP, 1988. Print.

Errico, Sally. “Dear Sugar's True Identity.” The New Yorker: February 14, 2012. The New Yorker. Web. 1 Dec. 2015.

Evans, James E. “Evelina, the Rustic Girls of Congreve and Abington, and Surrogation in the 1770's." The Eighteenth Century 52.2 (2011): 157-171. Web. JSTOR. 4 Aug. 2017.

Fein, Ellen and Sherrie Schneider. The Rules; Time-tested Secrets for Capturing the Heart of Mr. Right. New York: Warner Books, 1996. Print.

Fish, Stanley. Is There a Text in This Class? The Authority of Interpretive Communities. Cambridge: Harvard UP, 1982. Print.

Flint, Christopher. "The Anxiety of Affluence: Family and Class (Dis)order in Pamela, or, Virtue Rewarded." Studies in English Literature (SEL). 29 (Summer 1989): 489514. Web. JSTOR. 26 Jun. 2015.

Ford, Susan Allen. "Mr. Collins Interrupted: Reading Fordyce's Sermons with Pride and Prejudice." Persuasions On-Line. 34.1 (Winter 2013). Web. JASNA. 26 Aug. 2015.

Fordyce, James. Sermons to Young Women. 1st ed. London, 1766. EighteenthCentury Collections Online Web. 20 Mar. 2014.

Francus, Marilyn. "'Tis Better to Give: The Conduct Manual as Gift." The Culture of the Gift in Eighteenth-century England. Ed. Linda Zionkowski and Cynthia Klekar. 79106. New York: Palgrave, 2009. Print.

Frank, Marcie. “Frances Burney's Theatricality.” ELH 82.2 (Summer 2015): 615-635. 
Web. JSTOR. 4 Aug. 2017.

Friedan, Betty. The Feminine Mystique. New York: Dell Publishing Co., 1963. Print.

Gallagher, Catherine. Nobody's Story: The Vanishing Acts of Women Writers in the Marketplace, 1670-1820 (New Historicism-Studies in Cultural Poetics, No. 31). Berkeley: University of California Press, 1994. Print.

Gilbert, Sandra M., Susan Gubar. The Madwoman in the Attic: The Woman Writer and the Nineteenth-Century Literary Imagination $2^{\text {nd }}$ Edition. New Haven: Yale UP, 2000.

Greenfield, Susan C. “Monkeying Around in Evelina: Identity and Resemblance Again." The Eighteenth-Century Novel 6-7 (2009): 409-428. Web. ACMRS. 7 Aug. 2017.

--.. "Oh Dear Resemblance of Thy Murdered Mother": Female Authorship in Evelina." Eighteenth Century Fiction 3.4(July 1991): 301-320. Web. Project Muse. 20 Aug. 2017.

Grimm, Jacob and Willhelm, The Complete Grimm's Fairy Tales. New York: Pantheon Books: A Division of Random House, 1972. Print.

Gregory, James. "An Account of the Life and Writings of Dr. John Gregory." A Father's Legacy to his Daughters, TO Which is Prefixed, An Account of the Life of the Author. Edinburgh, 1788. Eighteenth-Century Collections Online. Web. 16 Mar. 2014.

--. "Preface" A Father's Legacy to his Daughters. By the Late Dr. Gregory of Edinburgh. A New Edition. London: 1774. Eighteenth-Century Collections Online. Web. 16 Mar. 2014.

Gregory, John. A Father's Legacy to his Daughters. By the Late Dr. Gregory of 
Edinburgh. A New Edition. London: 1774. Eighteenth-Century Collections Online.

Web. 16 Mar. 2014.

Hemlow, Joyce. "Fanny Burney and the Courtesy Books." PMLA 65.5 (1950):

732-761. Web. JSTOR. 2 Oct. 2013.

Johnson, Claudia L. Equivocal Beings: Politics, Gender, and Sentimentality in the

1790s-Wollstonecraft, Radcliffe, Burney, Austen. Chicago, Chicago UP, 1995. Print.

Jones, Vivien. ed. and introd. Evelina. New York: Oxford UP, 2008. Print.

---, ed. and introd. The Young Lady's Pocket Library, or Parental Monitor.

Bristol: Thoemmes Press, 1995. Print.

---, Women in the Eighteenth Century: Constructions of femininity.

New York: Routledge, 1997. Print.

Kennard, Lawrence R. “Reveries of Reality: Mary Wollstonecraft's Poetics of Sensibility." Mary Wollstonecraft and Mary Shelley: Writing Lives. Ed. Helen M. Buss, D.L. Macdonald, and Anne McWhir. Waterloo, ON: Wilfred Laurier UP, 2001. 55-68. Print.

Keymer, Thomas. Introduction to Pamela, or Virtue Rewarded. New York: Oxford UP, 2001. Print.

Keymer, Thomas, Peter Sabor and John Mullen, ed. The Pamela Controversy: Criticisms and Adaptations of Samuel Richardson's Pamela, 1740-1750. New York: Routledge, Taylor \& Francis Group, 2000. Print.

Leduc, Guyonne. “The dramatic import of letters within letters in Frances Burney's Evelina (1778)." Etudes Anglaises 67.1 (January-March 2014): 35-52. JSTOR. Web. 4 Aug. 2017. 
Mackenzie, Catriona. “Reason and Sensibility: The Ideal of Women's Self-Governance in the Writings of Mary Wollstonecraft." Hypatia 8.4 (Fall 1993): 35-55. Web. 3 Jan. 2018.

Maurer, Shaun Lisa. "The Female (As) Reader: Sex, Sensibility, and the Maternal in Wollstonecraft's Fictions." Essays in Literature. 19.1 (1992): 36-54. Print.

McKeon, Michael. The Secret History of Domesticity: Public, Private and the Division of Knowledge. Baltimore: Johns Hopkins UP, 2005. Print.

Moe, Melina. “Charlotte and Elizabeth: Multiple Modernities in Jane Austen’s Pride and Prejudice." ELH 83.4 (Winter 2016): 1075-1103. Web. JSTOR.1 Sept. 2017.

Morgan, Megan Stoner. "Pride and Potentiality: Doubling Elizabeth Bennet." Persuasions On-Line 32.1 (Winter 2011). Web. JASNA. 26 Aug. 2015.

Muller, Anja, ed. Fashioning Childhood in the Eighteenth Century. Burlington: Ashgate, 2006. Print.

O'Brien, Karen. Women and the Enlightenment in Eighteenth-Century Britain. New York: Cambridge UP, 2010. Print.

O'Malley, Andrew. The Making of the Modern Child: Children's Literature and Childhood in the Late Eighteenth Century. New York: Routledge, 2003. Print.

Ortberg, Mallory. "Do It For the Kids." Dear Prudence: Web Transcript Slate.com. 21 Dec. 2015. Web. 23 Dec. 2015.

--.. "I Am Dear Prudence Now Also In Addition To The Toast." The Toast. The Toast. 9 Nov. 2015. Web. 30 Nov. 2015.

---. “Revisiting Pamela: How To Read Books You Don't Want To." The Toast. The Toast. 27 Mar. 2014. Web. 27 Mar. 2014. 
---."Roll Over, Tchaikovsky" Dear Prudence: Web Transcript Slate.com. 23 Nov.

2015. Web. 25 Nov. 2015.

---. "Signs You're About To Write A Dear Prudence Letter." The Toast. The Toast. 1

Oct. 2015. Web. 30 Nov. 2015.

---. “Texts from Pride and Prejudice." The Hairpin. The Hairpin. Published on 20 Feb. 2013. Web. 5 Oct. 2015.

Pennington, Sarah. An Unfortunate Mother's Advice to Her Absent Daughters, in a Letter to Miss Pennington. $5^{\text {th }}$ ed. London, 1770. Eighteenth Century Collections Online. Web. 16 Mar. 2014.

Perrault, Charles. Histories or Tales of Past Times, Told By Mother Goose, with Morals 10 th Edition, 1791. Eighteenth-Century Collections Online Web. 14 Feb. 2018.

Perry, Ruth. Novel Relations: The Transformation of Kinship in English Literature and Culture, 1748-1818. New York: Cambridge UP, 2006. Print.

Pino, Melissa. "Burney's Evelina and Aesthetics in Action." Modern Philology (2010): 263-303. Web. JSTOR. 4 Aug. 2017.

Plotz, Judith. Romanticism and the Vocation of Childhood. New York: Palgrave, 2001. Print.

Poovey, Mary. The Proper Lady and the Woman Writer: Ideology as Style in the Works of Mary Wollstonecraft, Mary Shelley, and Jane Austen. Chicago: U of Chicago P, 1985. Print.

Radway, Janice A. Reading the Romance: Women, Patriarchy, and Popular Literature. Chapel Hill: University of North Carolina Press, 1991. Print.

Richardson, Alan. Literature, Education, and Romanticism: Reading as Social Practice, 
1780-1832. New York: Cambridge UP, 2004. Print.

Richardson, Samuel. Edited by Thomas Keymer and Alice Wakely. Pamela, or Virtue Rewarded. New York: Oxford UP, 2001. Print.

Roxburgh, Natalie. “Rethinking Gender and Virtue through Richardson's Domestic Accounting." Eighteenth-Century Fiction 23 no. 4 (Spring 2012): 403-429. Web. Project Muse. 26 Jun. 2015.

Schellenberg, Betty A. "Coterie Fame, Media Choice and the Writing Lives of Hester Mulso Chapone and Catherine Talbot." Women's Writing 21 no. 3 (2014): 316-336. Web. JSTOR. 10 Jun. 2017.

Simpson-Giles, Candace. How to Be a Lady: A Contemporary Guide to Common Courtesy. Nashville: Rutledge Hill Press, 2001. Print.

Strayed, Cheryl." Dear Sugar: The Rumpus Advice Column \#39: The Baby Bird." The Rumpus, June 3, 2010. The Rumpus.net 2012. Web. 1 Dec. 2015.

---. Tiny Beautiful Things: Advice on Life and Love from Dear Sugar. New York: Vintage Books, 2012. eBook. Downloaded 4 Feb. 2014.

Spacks, Patricia Meyer. Privacy: Concealing the Eighteenth-Century Self. Chicago: U of Chicago P, 2003. Print.

Starr, G. Gabrielle. "Burney, Ovid, and the Value of the Beautiful." Eighteenth-Century Fiction 24.1 (Fall 2011): 77-104. Web. JSTOR. 4 Aug. 2017.

St Clair, William. The Reading Nation in the Romantic Period. New York: Cambridge UP, 2007. Print.

Steele, Kathryn L. "Hester Mulso Chapone and the Problem of the Individual 
Reader." The Eighteenth Century: Theory and Interpretation 53. 4 (Fall 2012): 473-

491. Web. JSTOR. 26 Jun. 2015.

Stone, Lawrence. Road to Divorce: England 1530-1987. New York: Oxford UP, 1990.

Print.

Straub, Kristina. Domestic Affairs: Intimacy, Eroticism, and Violence between Servants and Masters in Eighteenth-Century Britain. Baltimore: Johns Hopkins UP, 2008. Print.

Steward, James Christen. The New Child: British Art and the Origins of Modern Childhood, 1730-1830. Berkeley: University Art Museum and Pacific Film Archive, U of California, Berkeley, 1995. Print.

$\mathrm{Su}$, Bernie, and Hank Green, executive producers. The Lizzie Bennet Diaries. Starring Ashley Clements, Julia Cho, Laura Spencer, and Mary Kate Wiles. YouTube Videos. Pemberly Digital. Premiered on April 9, 2012.

Tague, Ingrid H. 2002. Women of Quality: Accepting and Contesting Ideals of Femininity in England, 1690-1760. Woodbridge: The Boydell Press, 2002. Print. Taylor, Charles and Judith Butler, contributors. The Power of Religion in the Public Sphere. New York: Columbia UP, 2011. Print.

Tegan, Mary Beth. "Mocking the Mothers of the Novel: Mary Wollstonecraft, Maternal Metaphor, and the Reproduction of Sympathy." Studies in the Novel 42.4 (Winter 2010): 357-376. Web. Project Muse. 15 Sept. 2017

Thompson, Helen. "Evelina's Two Publics." The Eighteenth Century 39.2 (Summer 1998): 147-167. Web. JSTOR. 20 Jan. 2016.

Turnbull, Margaret. “Jane Austen and James Fordyce.” Sensibilities 34 (2007): 34-57. 
Web. JASNA. 26 Sept. 2017.

Todd, Janet. "Introduction." A Vindication of the Rights of Woman and a Vindication of the Rights of Men. New York: Oxford World's Classics, 2008. Print.

Vallone, Lynne. Disciplines of Virtue: Girls' Culture in the 18th and 19th Centuries. New Haven: Yale UP, 1995. Print.

Vareschi, Mark. "Motive, Intention, Anonymity and Evelina." ELH 82.4 (Winter 2015): 1135-1158. Web. Project Muse. 4 Aug. 2017.

"Virtue." Oxford English Dictionary: OED. Web. 15 Apr. 2018.

Vorachek, Laura. “Intertextuality and Ideology: Jane Austen's Pride and Prejudice and James Fordyce's Sermons to Young Women." English Faculty Publications, University of Dayton eCommons (2005): 129-137. Web. University of Dayton Press. 2 Feb. 2018.

Walker, A.D.M. "Aristotle's Account of Friendship in the "Nicomachean Ethics." Phronesis 24. 2 (1979):180-196, Brill Publishers. Web. 5 Feb. 2017.

Warner, Marina. From the Beast to the Blonde: On Fairy Tales and Their Tellers. New York: Farrar, Straus and Giroux, 1994. Print.

Wells, Juliette. "True Love Waits: Austen and Christian Romance in the Contemporary U.S." Persuasions On-Line 28.2 (Spring 2008). Web. JASNA. 26 Aug. 2015.

Wierda Rowland, Ann. Romanticism and Childhood: The Infantilization of British Literary Culture. New York: Cambridge UP, 2012. Print.

Wollstonecraft, Mary. A Vindication of the Rights of Woman. $3^{\text {rd }}$ ed. Ed. Deidre Shauna Lynch. New York: Norton, 2009. Print. 
Wong, Bethany. "Pamela Part II: Richardson's Trial by Theatre." Eighteenth-Century Fiction 29 no. 2 (Winter 2016-2017): 179-199. Web. Project Muse. 29 Jul. 2017. Wu, Yih-Dau. ““I Suppose It Is Not Sentimental Enough!”: Evelina and the Power of Feeling." Tamkang Review 45.2 (June 2015): 2-24. Web. ResearchGate. 4 Aug. 2017. 


\section{Acknowledgements}

This dissertation has been five years in the making, on top of the two years of Ph.D. coursework, and the two years of my Master's Degree in Boston prior to that, so there are many people I wish to thank now that my degree is completed.

My parents, Helen McEntee and Dominick Bruno, and my brother Alexander, thank you all for your guidance and support: intellectual, emotional, and otherwise throughout my life. Mom, thank you for introducing me to the work of Cheryl Strayed. Dad, thank you for verbally taking me through the construction of my keystone chapter about Jane Austen, and Alexander, thank you for modeling what it means to be a good literary citizen and critical thinker. To my fiancé, Nicholas Mick and to his family: his parents Willie and Jean Mick, and his brother and sister-in-law Jeff and Holly Mick: thank you all for talking when I needed to listen, listening when I needed to talk, and making coffee when I needed both. (And of course thank you to Nick's nephew Deacon Mick for when I needed to play with puppies, or jump on a trampoline.) To all of my family, Angela and Onofrio Bruno, Suzanne and Joe Bruno, Adrienne Bruno and Adam Lawson, Julia Bruno and Dave Pascarella, Eileen O'Brien, Lauren McEntee, Meaghan McEntee, all of my cousins and great aunts and uncles, and my relatives who passed away before they could see me complete this degree, especially James McEntee and Helen D. McEntee: thank you for always indulging my intellectual and literary fancies, and being proud of me no matter what the outcome.

Thank you to my committee members, and my colleagues who have supported me every step of the way, including the members of my department advising team: Elizabeth Levelle, Connie Toffle, Sharon Tenenholz, Elisa Krackow and Kris Martens. Thank you to my department head, Kevin Larkin, and all of the staff in the WVU Eberly College Department of Psychology, especially Selena Engebretson, Pam Darling, and Rebecca Herod. Thank you to my professional mentors, who have modeled the best practices of good citizenship in higher education, including Rudolph Bauer, Rosemarie Bodeheimer, Elizabeth KowaleskiWallace, and Frances Restuccia.

The author, historian, and social activist Elizabeth Catte recently described being Appalachian as "running toward your friends when they need you," so thank you to all of my friends who embody this Appalachian ethos, even if they didn't grow up here. Thank you to my oldest friends in the DC-Metro Area and Boston, especially to Katherine Masetti, Samantha Jones, and Christine Beaty for always supporting my writing, for proofreading my work, and for holding me accountable to academic rigor. And finally, thank you to my writer-friends here in West Virginia, for teaching me how to write with my most authentic voice. Thank you to Mays Ibraheem, Stephen Scott, Natalie Sypolt, Jason Kapcala, and especially to Renée Nicholson for sharing their wisdom, their understanding, and their compassion, both through their writing and in how they live their lives. Know that I will run toward you whenever you need me, and thank you for always doing the same. 